\title{
Redox behaviour of cymantrene Fischer carbene complexes in designing organometallic multi-tags
}

Daniela I. Bezuidenhout, ${ }^{[\mathrm{a}] *}$ Belinda van der Westhuizen, ${ }^{[\mathrm{a}]}$ Pieter J. Swarts, ${ }^{[\mathrm{b}]}$ Teshica Chatturgoon, ${ }^{[\mathrm{c}]}$ Orde Q. Munro, ${ }^{[\mathrm{c}]} *$ Israel Fernández, ${ }^{[\mathrm{d}]} *$ and Jannie C. Swarts ${ }^{[\mathrm{b}]} *$

[a] Dr D. I. Bezuidenhout, Ms B. van der Westhuizen

Chemistry Department

University of Pretoria

Private Bag X20, Hatfield 0028, Pretoria, South Africa

Tel: $(+) 27-12-420-2626$

E-mail: daniela.bezuidenhout@up.ac.za

[b] Mr P. J. Swarts, Prof J. C. Swarts

Chemistry Department

University of the Free State

PO Box 339, Bloemfontein 9300, South Africa

Tel: (+)27-51-401-2781

E-mail: swartsjc@ufs.ac.za

[c] Ms T. Chatturgoon, Prof O. Q. Munro

School of Chemistry \&Physics, University of KwaZulu-Natal

Pietermaritzburg 3209, South Africa

Tel: (+)27-33-260-5270

E-mail:munroo@ukzn.ac.za

[d] Dr I. Fernández

Departamento de Química Orgánica I, Facultad de Ciencias Químicas

Universidad Complutense de Madrid

Madrid 28040, Spain

Tel: $(+) 34-91-394-5155$

E-mail: israel@quim.ucm.es

Abstract: A series of group 7 Fischer carbene complexes of the type $\left[\mathrm{Cp}(\mathrm{CO}){ }_{2} \mathrm{Mn}{ }^{\prime}=\mathrm{C}(\mathrm{OEt}) \mathrm{Ar}\right](\mathrm{Cp}=$ cyclopentadienyl with $\mathrm{Ar}=\mathrm{Th}=$ thienyl (1a), Fu = furyl (2a), or Fc = ferrocenyl (3a)) and biscarbene complexes $\left[\mathrm{Cp}(\mathrm{CO})_{2} \mathrm{Mn}=\mathrm{C}(\mathrm{OEt})-\mathrm{Ar}^{\prime}-(\mathrm{OEt}) \mathrm{C}=\mathrm{Mn}(\mathrm{CO})_{2} \mathrm{Cp}\right]$ with $\mathrm{Ar}^{\prime}=\mathrm{Th}^{\prime}=$ 2,5-thienylene (1) $)$, Fu' = 2,5-furylene (2b) or 1,1'ferrocendiyl ( $\left.\mathrm{Fc}^{\prime}\right)(\mathbf{3 b})$ was synthesized and characterized. Chemical oxidation of $\left[\mathrm{Cp}(\mathrm{CO}){ }_{2} \mathrm{Mn}=\mathrm{C}(\mathrm{OEt}) \mathrm{Fc}\right](3 \mathrm{a})$ and isolation of the oxidised species [3a] $\left[\mathrm{PF}_{6}\right.$ ] possessing a $\mathrm{Mn}(\mathrm{II})$ centre proved possible below $-30^{\circ} \mathrm{C}$ in dichloromethane solution. The ESR spectrum of the transiently stable radical cation, [3a][ $\left.\mathrm{PF}_{6}\right]$, confirmed the presence of a low-spin $\mathrm{Mn}(\mathrm{II})$ centre characterized by a rhombic $g$-tensor $\left(g_{\mathrm{x}}=1.975, g_{\mathrm{y}}=2.007\right.$, and $\left.g_{\mathrm{z}}=2.130\right)$ in frozen dichloromethane at $77 \mathrm{~K}$ with ${ }^{55} \mathrm{Mn}$ hyperfine coupling constants $A_{1}, A_{2}$, and $A_{3}$ of 115,33 , and $43 \mathrm{G}$, respectively. Electrochemical studies demonstrated the influence of the Ar substituent on the oxidation potential. All complexes showed that the redox potentials of carbene double bond reduction and $\mathrm{Mn}(\mathrm{I})$ oxidation were dependent on the type of Ar group, but only $\mathbf{3 b}$ showed resolved oxidations for the two $\mathrm{Mn}(\mathrm{I})$ centres. Surprisingly, $\mathrm{Mn}(\mathrm{I})$ oxidation occurs at lower potentials than ferrocenyl oxidation. Density functional theory (DFT) calculations were carried out to delineate the nature of the species involved in the oxidation and reduction processes and clearly confirm that oxidation of $\mathrm{Mn}(\mathrm{I})$ is favoured over that of ferrocene.

\section{Introduction}

Organometallic molecular tags or labels employed to manipulate chemical and analytical properties of chemical targets mostly contain an electron-donating ferrocenyl moiety which provides a neat reversible one-electron oxidation process. ${ }^{[1]}$ The anodic electrochemistry of the ferrocenyl group leads to diverse applications including 
cancer therapy, ${ }^{[2]}$ molecular sensors, ${ }^{[3]}$ and energy transfer processes. ${ }^{[4]}$ The electron-withdrawing properties and IR-active carbonyl groups of a cymantrenyl moiety, $\mathrm{Mn}\left(\eta^{5}-\mathrm{C}_{5} \mathrm{H}_{4}\right)(\mathrm{CO})_{3},{ }^{\left[{ }^{[5]}\right.}$ make this organometallic compound an interesting and significantly different alternative as a molecular tag, although its redox chemistry has been underutilized. ${ }^{[6]}$ Despite the use of cymantrenyl cathodic chemistry for immunoassays, ${ }^{[7]}$ applications of cymantrenyl anodic chemistry are hitherto lacking. This dearth can be attributed not only to the high oxidation potential of the cymantrene unit ( $c a .0 .9 \mathrm{~V}$ vs. ferrocene) as a result of the effect of the $\pi$-accepting carbonyl groups, ${ }^{[8]}$ but also to the instability of the radical cation which is still poorly understood. This paper addresses the first of these points by substituting one carbonyl ligand with a less $\pi$-accepting ligand, namely a heteroatomsubstituted carbene ligand. Studies of triphenylphosphane-substituted cymantrenyl complexes showed that the thermodynamic and kinetic stabilities of the cationic complexes are greatly enhanced. ${ }^{[9]}$ The effect of employing Fischer carbenes as weaker $\pi$-acceptors than carbonyls is herein imposed by synthesizing a series of cymantrene Fischer alkoxycarbene complexes containing heteroaryl (thienyl, Th, or furyl, Fu) substituents. Both the monoand the biscarbene complexes with bridging 2,5-thienylene ( $\left.T h^{\prime}\right)$ or 2,5-furylene (Fu') carbene substituents, were prepared. Fischer carbene complexes of the type $\left[(C O)_{5} M=C(X) R\right](M=$ group 6 transition metal) are very well studied $^{[10]}$ and the electrochemical activity of these group 6 carbene complexes has recently been thoroughly investigated. ${ }^{[11]}$ In contrast, examples of the group 7 type, $\left[\mathrm{Cp}(\mathrm{CO}){ }_{2} \mathrm{Mn}=\mathrm{C}(\mathrm{X}) \mathrm{R}\right],{ }^{[12]}$ are not as common, and reports on their redox behaviour are scarce. ${ }^{[13]}$ Fine-tuning of the steric and electronic properties of the carbene moiety can be effected by modulation of the carbene substituents $\left(X=\right.$ heteroatom substituent, $R=$ aryl substituent). ${ }^{[14]}$ The introduction of a metal-containing substituent, such as ferrocenyl, opens the door for the design of organometallic multi-tag complexes. To this end, mono-and biscarbene ferrocenyl complexes were also synthesized. Electrochemical, ESR, and molecular orbital investigations of these complexes as examples of possible anodic redox multi-tags are reported herein.

\section{Results and Discussion}

Synthesis: A series of cyclopentadienyl dicarbonyl manganese carbene complexes was synthesised according to the classical procedure reported by Fischer and Maasböl. ${ }^{[15]}$ Lithiation of the (hetero)arene precursors yielded a mixture of both the mono- and dilithiated (hetero)arene. The reaction mixture was reacted with 2 equivalents of $\mathrm{CpMn}(\mathrm{CO})_{3}$ to produce the corresponding metal acylate and dimetal bisacylate complexes, which, after alkylation with Meerwein's reagent, ${ }^{[16]}$ yielded both the neutral ethoxy-monocarbene and biscarbene complexes (Scheme 1).

Chemical oxidation of the $\mathrm{Mn}(\mathrm{I})$ centre of 3a was achieved by the use of $\operatorname{AgPF}_{6}{ }^{[17]}$ (Scheme 2) to yield the radical $\mathrm{Mn}(\mathrm{II})$ species [3a][ $\mathrm{PF}_{6}$ ]. All neutral compounds were purified by column chromatography to give products as dark yellow to brown (Th, $\mathrm{Fu}$ ) or dark red to maroon $\left(\mathrm{Fc}\right.$ ) solids. Complexes (except $\mathbf{2 b}^{\left[{ }^{[18]}\right.}$ and $[\mathbf{3 a} \mathbf{}]\left[\mathrm{PF}_{6}\right]$ ) were stable in the absence of oxygen and could be stored for months under argon in the cold, however decomposition could be detected after 30 min in $\mathrm{C}_{6} \mathrm{D}_{6}$ and $\mathrm{CH}_{2} \mathrm{Cl}_{2}$ during electrochemical studies, but allowed enough time for electrochemical and spectroscopic studies to be completed.

Spectroscopy: By employing NMR and IR spectroscopy, electronic effects of the carbene substituents could be followed (Table 1). Both the $\alpha$ and $\beta$ protons in the ${ }^{1} H$ NMR are deshielded as a result of $\pi$-resonance stabilization effects due to the coordination of the metal-carbene moiety. For the thienyl and ferrocenyl complexes (1a, 1b, 3a and $\mathbf{3 b}$ ) the $\mathrm{H}_{\alpha}$ is used as a probe as it is most sensitive towards electronic ring substituent involvement. However, for furyl complexes ( $\mathbf{2} \mathbf{a}$ and $\mathbf{2} \mathbf{b}$ ) the $\mathrm{H}_{\mathrm{\gamma}}$ resonances are used as a probe as these proton shifts show a more 
downfield shift compared to the $\mathrm{H}_{\alpha}$. The assignment of the thienyl and furyl ring proton chemical shifts is based on assignments following predicted shifts for ester derivatives. ${ }^{[19]}$ No usable NMR spectra could be obtained for the paramagnetic [3a] $\left[\mathrm{PF}_{6}\right]$. The expected band pattern ${ }^{[20]}$ associated with the carbonyl stretches of a $\left[\mathrm{CpMn}(\mathrm{CO})_{2} \mathrm{~L}\right]$ system could be observed in the infrared spectra of all complexes, with very similar stretching frequencies (Table 1). The wavenumbers observed for complex [3a][PF ${ }_{6}$ (Figure 1) show a significant shift of the carbonyl stretching mode bands to higher frequency, consistent with coordination to a $\mathrm{Mn}$ (II) ion and diminished metal-to-ligand $\pi$-back-donation due to the higher metal oxidation state and reduced d-electron density. Furthermore, the bands fall well within the expected range for the one-electron oxidation of a "piano-stool" complex. Thus, the average shift of $116 \mathrm{~cm}^{-1}$ from that of neutral 3a compares favourably with that previously reported for cationic cymantrene complexes $\left(\sim 115 \mathrm{~cm}^{-1}\right){ }^{[6]}$

Table 1. Selected NMR and IR spectroscopic data.

\begin{tabular}{cccc}
\hline Complex & $\begin{array}{c}\mathrm{H}_{\text {probe }} \\
\left({ }^{1} \mathrm{H} \text { NMR, ppm }\right)^{[\mathrm{a}]}\end{array}$ & $\begin{array}{c}\mathrm{C}_{\text {carbene }} \\
\left({ }^{13} \mathrm{CNMR}_{\mathrm{ppm}}\right)^{[\mathrm{a}]}\end{array}$ & $\begin{array}{c}\mathrm{IR} \\
\left(\mathrm{cm}^{-1}\right)^{[\mathrm{b}]}\end{array}$ \\
\hline 1a & 6.93 & 319 & 1936,1872 \\
1b & 7.52 & 319 & 1948,1896 \\
2a & 6.71 & 309 & 1942,1876 \\
2b & 6.84 & 306 & 1935,1886 \\
3a & 4.83 & 328 & 1938,1862 \\
3b & 4.92 & 336 & 1927,1858 \\
{$[3 a]\left[\mathrm{PF}_{6}\right]$} & - & - & 2042,1978 \\
\hline
\end{tabular}

[a] Spectra recorded in $\mathrm{C}_{6} \mathrm{D}_{6}$. [b] Spectra recorded in $\mathrm{CH}_{2} \mathrm{Cl}_{2}$.

The DFT-calculated IR spectra for $\mathbf{3 a}$ and $\mathbf{3} \mathbf{a}^{\circ+}$ (Figure 1 ) reproduced the key carbonyl band shifts upon oxidation of 3a in the experimental spectrum to within 11 and $16 \mathrm{~cm}^{-1}$ for the antisymmetric and symmetric stretching modes, respectively. Moreover, the calculated peak separation between the two $\mathrm{CO}$ modes for the $\mathrm{Mn}(\mathrm{I})$ complex (68 $\left.\mathrm{cm}^{-1}, 3 a\right)$ and $\mathrm{Mn}(\mathrm{II})$ complex $\left(70 \mathrm{~cm}^{-1}, 3 \mathrm{a}^{-+}\right)$fell within 6 wavenumbers of the experimental peak separation. Note that the absolute frequencies of the calculated peaks are not expected to correlate exactly with those measured experimentally due to intrinsic limitations in the calculation method. ${ }^{[21]}$ That said, a scaling factor of 0.961 for the carbonyl frequencies calculated at the HSEH1PBE/6-311+g(d,p) level of theory (in $\mathrm{CH}_{2} \mathrm{Cl}_{2}$ ) would bring the theoretical spectra into the correct frequency range for direct comparisons with the experimental spectra to be made. The DFT-calculated $\mathrm{Mn}(\mathrm{I} / \mathrm{II})$ coordination geometries (Figure 1 ) are in excellent agreement with the $\mathrm{X}$-ray data reported for the neutral and oxidized forms of the cymantrene derivative $\mathrm{Mn}\left(\eta^{5}-\mathrm{C}_{5} \mathrm{H}_{4} \mathrm{NH}_{2}\right)(\mathrm{CO})_{3}{ }^{[6]}$ For example, the $\mathrm{Mn}-\mathrm{CO}$ distances average 1.80(1) $\AA$ in the experimental structure (the data do not allow a distinction between $\mathrm{Mn}^{\prime}$ and $\mathrm{Mn}^{\prime \prime}$ to be made). In the simulated structures of $3 \mathrm{a}$ and $3 \mathrm{a}^{\circ+}$, the $\mathrm{Mn}-\mathrm{CO}$ bonds contract from 1.83(1) $\AA$ to 1.77(1) $\AA$ upon oxidation of the metal. The $M n=C$ bond shows a similar contraction from 1.98 to $1.91 \AA$ with the change in oxidation state of the manganese ion.

Electrochemistry: Cyclic voltammetry (CV), linear sweep voltammetry (LSV), and Osteryoung square wave voltammetry (SW) were conducted on $\mathbf{1 - 3} \mathbf{3}^{[18]}$ in $\mathrm{CH}_{2} \mathrm{Cl}_{2}$ utilizing $0.1 \mathrm{~mol} \cdot \mathrm{dm}^{-3}\left[\mathrm{~N}\left({ }^{n} \mathrm{Bu}\right)_{4}\right]\left[\mathrm{PF}_{6}\right]$ as supporting electrolyte in a glove box having oxygen and moisture levels less than 5 ppm. CV's are shown in Figures 2 and 4 while data are summarized in Table 2.

As was the case with previously reported chromium ${ }^{[22]}$ and tungsten ${ }^{[23]}$ Fischer ethoxycarbene complexes, $\left[(\mathrm{CO})_{5} \mathrm{M}=\mathrm{C}(\mathrm{OEt}) \mathrm{Ar}\right]$ with $\mathrm{M}=\mathrm{Cr}(0)$ or $\mathrm{W}(0)$, reduction of the $\mathrm{Cp}(\mathrm{CO})_{2} \mathrm{Mn}^{\prime}=\mathrm{C}$ carbene double bond to $\mathrm{a}^{-} \mathrm{Mn}^{\prime}-\mathrm{C} \bullet$ species is observed at low potentials ( $<-2.0 \mathrm{~V}$ vs $\mathrm{FcH} / \mathrm{FcH}^{+}$, wave I, Figure 2 and Table 2). However, in the $\mathrm{Cr}$ and 
W systems, the metals were in the zero oxidation state. In the present series of compounds, $\mathrm{Mn}$ is in the +1 oxidation state. Our computational results ${ }^{[24]}$ are mutually consistent with the electrochemistry in showing that this reduction is not a $\mathrm{Mn}(\mathrm{I})$ reduction to $\mathrm{Mn}(0)$. Figure 3 shows the computed frontier molecular orbitals of complex $\mathbf{2 a}$, where the carbene ligand adopts a vertical coordination mode and the ethoxy-group is oriented towards the carbonyl ligands (in the so-called anti-conformation). This conformation is reported to be the most stable conformation in similar manganese(I)-alkoxycarbene complexes. ${ }^{[25]}$ The LUMO is mainly centred in the $p_{z}$ atomic orbital of the carbene carbon atom. Therefore, it should be expected that the one-electron reduction process should lead to the radical anion $\mathbf{2 a ^ { - - }}$ whose unpaired electron remains mainly located in the $p_{z}$ orbital of the carbene carbon atom. Indeed, the computed spin density on $2 a^{\circ-}$ indicates a value of 0.55 e on the carbene carbon atom, thus confirming the assignment of ${ }^{-} \mathrm{Mn}-\mathrm{C} \bullet$ as reduction product (Figure 3). Similar LUMO's were observed for the rest of the mono- and biscarbene complexes considered in this study.

Table 2. Cyclic voltammetry data for $0.5 \mathrm{mmol} \cdot \mathrm{dm}^{-3}$ solutions of $\left[\mathrm{Cp}(\mathrm{CO})_{2} \mathrm{Mn}=\mathrm{C}(\mathrm{OEt})\right] \mathrm{Ar}$ and $\left[\mathrm{Cp}(\mathrm{CO})_{2} \mathrm{Mn}=\mathrm{C}(\mathrm{OEt})-\mathrm{Ar}\right.$ $\left.(\mathrm{OEt}) \mathrm{C}=\mathrm{Mn}(\mathrm{CO})_{2} \mathrm{Cp}\right]$ complexes 1-3 in $\mathrm{CH}_{2} \mathrm{Cl}_{2}$ containing $0.1 \mathrm{~mol} \cdot \mathrm{dm}^{-3}\left[\mathrm{~N}\left({ }^{n} \mathrm{Bu}\right)_{4}\right]\left[\mathrm{PF}_{6}\right]$ as supporting electrolyte at a scan rate of $100 \mathrm{mV} \mathrm{s}^{-1}$ and $20^{\circ} \mathrm{C}$. Potentials are relative to the $\mathrm{FcH} / \mathrm{FcH}^{+}$couple.

\begin{tabular}{|c|c|c|c|}
\hline Complex & Peaks obs. & $\mathrm{E}^{\mathrm{o}^{\prime}} / \mathrm{V}, \Delta \mathrm{E} / \mathrm{mV}$ & $\mathrm{i}_{\mathrm{p}} / \mu \mathrm{A}, \mathrm{i}_{\mathrm{p} c} / \mathrm{i}_{\mathrm{pa}}$ \\
\hline \multirow{2}{*}{ 1a $A r=T h$} & I (carbene) & $-2.065,76$ & $1.60,0.73^{\mathrm{a}}$ \\
\hline & 1 (Mn) & $0.015,73$ & $5.82,0.87$ \\
\hline \multirow{2}{*}{$\mathbf{1 b} A r^{\prime}=T h^{\prime}$} & I (carbene) & $-2.211,246$ & $18.7,0.10^{\mathrm{a}}$ \\
\hline & $1 a, b(M n)$ & $0.083,214$ & $5.82,0.87$ \\
\hline & I (carbene) & $-2.334,-^{b}$ & $1.44,-{ }^{b}$ \\
\hline \multirow[t]{2}{*}{$2 \mathrm{a} A r=\mathrm{Fu}$} & $1(\mathrm{Mn})$ & $0.086,92$ & $1.40,0.91$ \\
\hline & 2 (OEt) & $1.166,-^{b}$ & $4.12,-$ \\
\hline
\end{tabular}

The carbene double bond of $\mathbf{1}(\mathrm{Ar}=\mathrm{Th})$ and $\mathbf{2}(\mathrm{Ar}=\mathrm{Fu})$ is reduced at potentials at least $300 \mathrm{mV}$ smaller (more negative) than the $\mathrm{Cr}(0)$ analogues. ${ }^{[22]}$ This implies that compared to $\mathrm{Cr}^{0}(\mathrm{CO})_{5}$, the $\mathrm{CpMn}^{\prime}(\mathrm{CO})_{2}$ fragment is more electron-donating despite the metal being in the +1 oxidation state. As a consequence, the electrophilic nature of the carbene carbon atom is reduced in these group 7 Fischer carbene complexes as confirmed by the computed higher $p_{\mathrm{z}}$ occupation of the carbene carbon atom of $2 \mathrm{a}(0.74 \mathrm{e})$ compared to its $\mathrm{Cr}(0)$-carbene counterpart (0.63e), which is translated into a more difficult reduction. For $\mathrm{Ar}=\mathrm{Fc}$, reduction of the $\mathrm{M}=\mathrm{C}$ double bond was only observed for the biscarbene complex $\mathbf{3 b}$. Repeated experiments with $\mathbf{3 a}$ failed to show the carbene reduction within the allowed potential window of $\mathrm{CH}_{2} \mathrm{Cl}_{2}$. This finding correlates with the computed energy of the corresponding LUMO's (3b: $-1.88 \mathrm{eV}<2 \mathrm{a}:-1.83 \mathrm{eV}<3 \mathbf{a}:-1.64 \mathrm{eV}$ ) which indicates that the reduction process should be much easier for complexes $\mathbf{3} \mathbf{b}$ and $\mathbf{2} \mathbf{a}$ than for $\mathbf{3 a}$, as experimentally observed (see Table 2 ). The spread of reduction potentials of wave $\mathrm{I}$ in the range $-2.334<\mathrm{E}^{\mathrm{O}^{\prime}} \leq-2.065 \mathrm{~V}\left(\mathrm{E}^{\mathrm{O}^{\prime}}{ }_{3 \mathrm{a}}\right.$ fell outside the lower limit of this range) is indicative of good electrochemical interaction between the $\mathrm{Ar}=\mathrm{Fu}$, Th or $\mathrm{Fc}$ group and the $\mathrm{Mn}^{\prime}=\mathrm{C}$ moieties in 13.

Free ferrocene and cymantrene each display a one-electron oxidation with $E^{0^{\prime}}=1 / 2\left(E_{p a}+E_{p c}\right)$ of cymantrene $0.92 \mathrm{~V}$ vs. $\mathrm{FcH} / \mathrm{FcH}^{+} ;{ }^{[6]}$ electrochemical and chemical reversibility of the cymantrenyl moiety is not as good as with 
the ferrocenyl fragment. ${ }^{[6,17,26,27]}$ Electrochemical reversibility is associated with $\Delta E=E_{p a}-E_{p c}=59 \mathrm{mV}$ and $i_{p c} / i_{p a}=$ 1. ${ }^{[27]}$ Surprisingly, in the present carbene derivatised cymantrene series of compounds, Mn oxidation was found to occur at potentials comparable to free ferrocene. In particular, for $\mathbf{3} \mathbf{a}$ and $\mathbf{3 b}$, results from the present electrochemical, computational and ESR study (see below) were mutually consistent in showing that $\mathrm{Mn}^{\prime}$ is oxidised before $\mathrm{Ar}=$ ferrocenyl at wave 1 in the potential range $-0.106<\mathrm{E}^{\mathrm{o}^{\prime}}<0.086 \mathrm{~V}$. For the biscarbene complex $\left[\mathrm{Cp}(\mathrm{CO})_{2} \mathrm{Mn}=\mathrm{C}(\mathrm{OEt})-\mathrm{Ar}^{\prime}-(\mathrm{OEt}) \mathrm{C}=\mathrm{Mn}(\mathrm{CO})_{2} \mathrm{Cp}\right], \mathrm{Ar}^{\prime}=\mathrm{Fc}^{\prime}$, relaying of the electrostatic effects of the mixed-valent intermediate $\left[\mathrm{Cp}(\mathrm{CO})_{2} \mathrm{Mn}^{\prime \prime}=\mathrm{C}(\mathrm{OEt})-\mathrm{Ar}^{\prime}-(\mathrm{OEt}) \mathrm{C}=\mathrm{Mn}^{\prime}(\mathrm{CO})_{2} \mathrm{Cp}\right]$ manifested in the splitting of the oxidation peak in two components, waves $1 \mathrm{a}$ and $1 \mathrm{~b}$ in Figure 2.

The above described results show that the present cymantrene-carbene derivatives behave very different compared to the previously studied group $6 \mathrm{Cr}^{0}(\mathrm{CO})_{5}$ and $\mathrm{W}^{0}(\mathrm{CO})_{5}$ Fischer carbene complexes. Differences in $\left[\mathrm{L}^{1} \mathrm{~L}^{2} \mathrm{M}=\mathrm{C}(\mathrm{OEt})-\mathrm{Ar}\right]$ complexes (and by implication also the biscarbene analogues) may be summarised as follows:

a) For $\mathrm{L}^{1} \mathrm{~L}^{2} \mathrm{M}=(\mathrm{CO}){ }_{5} \mathrm{Cr}^{0}, \mathrm{Cr}(0)$ is first oxidised electrochemically reversibly to $\mathrm{Cr}(\mathrm{I})$ at $\mathrm{E}^{\mathrm{O}^{\prime}}=0.29 \mathrm{~V}$, then $\mathrm{Ar}=\mathrm{Fc}$ is oxidised electrochemically reversibly to $\mathrm{Fc}^{+}$at $\mathrm{E}^{\mathrm{o}^{\prime}}=0.70 \mathrm{~V}$ and finally $\mathrm{Cr}(\mathrm{I})$ is oxidised electrochemically irreversibly to $\mathrm{Cr}(\mathrm{II})$ at $\mathrm{E}^{\mathrm{o}^{\prime}}>1.15 \mathrm{~V}$. For $\mathrm{Ar}=\mathrm{Fu}$ or $\mathrm{Th}$ chromium carbene analogues, the irreversible $\mathrm{Cr}^{1 / 11}$ couple is between 0.95 and $1.15 \mathrm{~V}$ (See Figure S1). ${ }^{[20]}$

b) For $\mathrm{L}^{1} \mathrm{~L}^{2} \mathrm{M}=(\mathrm{CO})_{5} \mathrm{~W}^{0}, \mathrm{Ar}=\mathrm{Fc}$ is first oxidised electrochemically reversibly (see Figure $\mathrm{S} 1$ ) to $\mathrm{Fc}^{+}$at $\mathrm{E}^{\mathrm{O}^{\prime}}=0.29$ $-0.31 \mathrm{~V}$ depending on what electrolyte is used. $\mathrm{W}(0)$ is irreversibly oxidised to $\mathrm{W}(\mathrm{II})$ at $\mathrm{E}_{\mathrm{pa}}=1.11 \mathrm{~V}$ in two overlapping one-electron transfer steps in the presence of $\left[\mathrm{N}\left({ }^{n} \mathrm{Bu}\right)_{4}\right]\left[\mathrm{B}\left(\mathrm{C}_{6} \mathrm{~F}_{5}\right)_{4}\right]$ as supporting electrolyte, but to $\mathrm{W}(\mathrm{III})$ in three near-overlapping one-electron transfer steps at $0.81 \mathrm{~V}$ in the presence of $\left[\mathrm{N}\left({ }^{\mathrm{n}} \mathrm{Bu}\right)_{4}\right]\left[\mathrm{PF}_{6}\right]$ as supporting electrolyte. ${ }^{[23]}$

c) For $\mathrm{L}^{1} \mathrm{~L}^{2} \mathrm{M}=\mathrm{Cp}(\mathrm{CO})_{2} \mathrm{Mn}^{\prime}$, compound 3a, $\mathrm{Mn}(\mathrm{I})$ is first oxidised electrochemically reversibly to $\mathrm{Mn}(\mathrm{II})$ at $\mathrm{E}^{\mathrm{O}^{\prime}}=$ $-0.106 \mathrm{~V}(\Delta \mathrm{E}=96 \mathrm{mV})$, and then $\mathrm{Ar}=\mathrm{Fc}$ is oxidised electrochemically reversibly to $\mathrm{Fc}^{+}$at $\mathrm{E}^{\mathrm{o}^{\prime}}=0.442 \mathrm{~V}(\Delta \mathrm{E}=92$ $\mathrm{mV}$, Table 2). Although strictly speaking $\Delta \mathrm{E}=59 \mathrm{mV}$ is diagnostic of electrochemical reversibility, ${ }^{[28]}$ electrochemical reversible redox processes of the ferrocenyl group is universally accepted. Since $\Delta \mathrm{E}$ for the Fc and $\mathrm{Mn}$ redox processes are for all practical purposes identical, we conclude that electrochemical reversibility of the cymantrenyl group is comparable with that of a ferrocenyl group in the present series of group 7 Fisher carbene complexes.

d) Only complex $2 \mathrm{a}(\mathrm{Ar}=\mathrm{Fu})$ showed an additional oxidative process at $\mathrm{E}_{\mathrm{pa}}=1.166 \mathrm{~V}$. In analogy to the $\mathrm{Cr}^{1 / 11}$ and $\mathrm{W}^{0 / 111}$ couples, we believe that this may be an irreversible $\mathrm{Mn}^{11 / 11}$ couple. However, all other complexes failed to show this redox process within the potential window of the solvent.

e) In terms of chemical reversibility, carbene reduction was almost irreversible with $\mathrm{i}_{\mathrm{pa}} / \mathrm{i}_{\mathrm{pc}}$ very small $(0-$ 0.73; Table 2), but $\mathrm{Mn}(\mathrm{I})$ reductions was better than $85 \%$ reversible and in some cases approached $93 \%$ (Table 2). Interestingly though, on LSV time scale, the ferrocenyl complexes showed the oxidised species $\left[\mathrm{Cp}(\mathrm{OC})_{2} \mathrm{Mn}^{\prime \prime}=\mathrm{C}(\mathrm{OEt})\left(\mathrm{Fc}^{+}\right)\right], 3 \mathrm{a}^{2+}$, began to decompose notably before the LSV experiment is completed (Figure 4).

f) Wave Fc for 3b, $\left[\mathrm{Cp}(\mathrm{CO}){ }_{2} \mathrm{Mn} n^{\prime}=\mathrm{C}(\mathrm{OEt})-\mathrm{Fc}-(\mathrm{OEt}) \mathrm{C}=\mathrm{Mn}^{\prime}(\mathrm{CO}){ }_{2} \mathrm{Cp}\right]$, does not exhibit the usual ideal $\mathrm{CV}$ shape. The cathodic peak is much sharper than expected. A similar observation was made for $\left[(\mathrm{CO}){ }_{5} \mathrm{Cr}=\mathrm{C}(\mathrm{OEt})-\mathrm{Fc}\right.$ $\left.(\mathrm{OEt}) \mathrm{C}=\mathrm{Cr}(\mathrm{CO})_{5}\right]^{[22]}$ but $\mathrm{i}_{\mathrm{pc}} / \mathrm{i}_{\mathrm{pa}}$ for the manganese derivative was better (1.38 versus $\left.>10\right)$. The unusually large $\mathrm{i}_{\mathrm{pc}}$ value for wave $\mathrm{Fc}$ in $\mathbf{3 b}$ is attributed to electrode deposition of $\mathbf{3 b}^{\mathbf{3 +}}$, the fully oxidised product (Scheme 3 ) onto the active surface of the electrode. 
Scheme 3 highlights the proposed electrochemical pathway of the observed redox processes of $\mathbf{3 b}$. The other ethoxybiscarbene complexes undergo essentially the same processes although wave 1 is not resolved into two separate one-electron transfer processes, and the ferrocenyl wave is absent.

DFT simulations-redox chemistry: In order to gain more insight into the oxidation processes and the nature of the species involved, a Density Functional Theory (DFT) study was carried out. ${ }^{[24]}$ We first focused on the oxidation process of complex $\mathbf{2 a}$. As depicted in Figure 3, the HOMO of $\mathbf{2 a}$ (i.e. the orbital from which the electron is released) is mainly located on a doubly occupied $d$ atomic orbital of the manganese atom. This orbital nicely represents the $\pi$-backdonation of the transition metal to the vacant $p_{z}$ atomic orbital of the carbene carbon atom. Therefore, the one-electron oxidation should lead to a radical cation where the unpaired electron is mainly located at the manganese. The computed spin density on $2 \mathrm{a}^{\circ+}$ indicates a value of $1.21 \mathrm{e}$ on the transition metal atom thus confirming the assignment of $\mathrm{Cp}(\mathrm{CO})_{2} \mathrm{Mn}^{\| \bullet}=\mathrm{C}(\mathrm{OEt}) \mathrm{Fu}$ as oxidation product (Figure 5a).

The second oxidation process was tentatively assigned to the formation of the corresponding $\mathrm{Mn}$ (III) dication $\mathbf{2} \mathrm{a}^{2+}$ (see above). Our calculations nicely agree with this assignment and reveals that the dication $\mathbf{2} \mathrm{a}^{2+}$ presents a peculiar bonding situation which is markedly different to the structures of $2 a$ and the radical cation $\mathbf{2 a} \cdot^{+}$. As a consequence of the oxidation process which eliminates the two electrons of the HOMO of $\mathbf{2 a}$ (located at the manganese), the transition metal is prone to accept more electron density from the carbene ligand. Indeed, a clear C-H agostic interaction is present in $\mathbf{2} \mathrm{a}^{\mathbf{2 +}}$ as confirmed by the computed short Mn $\cdots \cdot$ HC distance of $1.919 \AA$ (Figure 5a). Additionally, the Atoms in Molecules (AIM) method further supports the existence of this agostic interaction. As seen in Figure $5 b$, the Laplacian distribution of $2 a^{2+}$ in the $\mathrm{Mn}-\mathrm{H}-\mathrm{C}$ plane clearly reveals the occurrence of a bond critical point located between the transition metal and the hydrogen atom, which is associated with a bond path running between these two atoms. Moreover, the computed value of 0.038 e $\AA^{-3}$ for the electron density at the bond critical point is in the range expected for $\mathrm{CH}$ agostic interactions. ${ }^{[28]}$ The bonding situation of $2 \mathrm{a}^{2+}$ resembles that found for related pentacarbonylchromium $(0)$ and tungsten $(0)$ carbene complexes formed upon 2-electron oxidation of the transition metal, ${ }^{[22,22]}$ which indicates that this bonding situation seems to be general for oxidized Fischer carbene complexes regardless of the transition metal and associated ligands.

We then considered the oxidation processes of the ferrocenyl substituted carbene complexes $\mathbf{3} \mathbf{a}$ and $\mathbf{3} \mathbf{b}$. Analogously to $\mathbf{2 a}$, the one-electron oxidation of $\mathbf{3 a}$ leads to the formation of the radical cation $3 \mathbf{a}^{\bullet++}$ whose unpaired electron is mainly located at the manganese (computed spin density of $1.21 \mathrm{e}$ ). This result confirms the above electrochemical conclusion that the manganese is oxidized before the iron atom and is consistent with the ESR spectrum of $3 a^{\circ+}$. Subsequent one-electron oxidation may lead to two different species, namely the openshell singlet complex formed upon oxidation of the Fe(II) to Fe(III) or, alternatively, the closed-shell singlet involving the oxidation of the $\mathrm{Mn}$ (II) to $\mathrm{Mn}$ (III). Our calculations reveal that the former species is $26.4 \mathrm{kcal} / \mathrm{mol}$ more stable than the latter, thus suggesting that the dication $3 \mathrm{a}^{\mathbf{2}}$ presents two unpaired electrons (computed spin densities of -1.26 and 1.30 for $\mathrm{Mn}$ and Fe, respectively, see Figure 6a).

A similar behaviour can be found in biscarbene complexes $3 \mathbf{b}$. As readily seen in Figure $6 \mathrm{~b}$, the first oneelectron oxidation involves the $\mathrm{Mn}(\mathrm{I})$ to $\mathrm{Mn}(\mathrm{II})$ reaction to produce the radical cation $\mathbf{3} \mathbf{b}^{\mathbf{}}{ }^{\mathbf{}}$. This process is followed by the oxidation of the other manganese centre to produce the open-shell singlet $\mathbf{3} \mathbf{b}^{\mathbf{+ 2}}$. Finally, the $\mathrm{Fe}(\mathrm{II})$ to $\mathrm{Fe}$ (III) oxidation occurs to form complex $3 \mathbf{b}^{0+3}$ in which each metal bears an unpaired electron. Therefore, our calculations fully support the electrochemical pathway proposed in Scheme 3.

ESR spectroscopy: Lastly, we carried out an ESR analysis of the chemically oxidised product [3a][PF 6 to 
experimentally support the above computational assignment of the radical cation as a $\mathrm{Cp}(\mathrm{CO})_{2} \mathrm{Mn} " \bullet-\mathrm{C}$ species. Briefly, [3a] $\left[\mathrm{PF}_{6}\right.$ ] was generated by $\mathrm{AgPF}_{6}$-mediated oxidation of $3 \mathrm{a}$ at $-41^{\circ} \mathrm{C}_{\text {in }} \mathrm{CH}_{2} \mathrm{Cl}_{2}$ (Scheme 2); transfer of the solution to a gas-tight ESR tube after $7 \mathrm{~min}$ followed by immediately recording the $\mathrm{X}$-band ESR spectrum at $77 \mathrm{~K}$ permitted observation of a clean spectrum of the transiently stable radical cation (Figure 7). (Note that a sample removed from the reaction vessel after 35 min afforded only a low-resolution, low-intensity ESR spectrum indicative of time-dependent decay of [3a][$\left[\mathrm{PF}_{6}\right]$ to one or more ESR-silent species in solution.) The ESR spectrum of $3 \mathrm{a}^{\circ+}$ is characterized by a rhombic $g$-tensor with the components $g_{\mathrm{z}}=2.130, g_{\mathrm{y}}=2.007$, and $g_{\mathrm{x}}=1.975$. Each $g$ component is, furthermore, split into six lines as a result of hyperfine coupling to the ${ }^{55} \mathrm{Mn}$ nucleus $(I=5 / 2,100 \%)$. While the hyperfine coupling clearly confirms oxidation of $M n(I)$ (diamagnetic low-spin $\left.d^{6}\right)$ to $M n(I I)\left(S=1 / 2 d^{5}\right)$, the ensuing peak overlap significantly complicates interpretation of the derivative spectrum and creates difficulties not only when attempting to locate the $g$-tensor components, but also when attempting to delineate the hyperfine coupling constants ( $A$-values). We found that deconvolution of the ESR absorption spectrum (Figure 7a) into a summation of Voigt functions ${ }^{[30]}$ partly simplified the task of locating the $g$-tensor components and measuring the hyperfine coupling constants from the experimental spectrum. As is customary in spectroscopy, ${ }^{[30]}$ we chose to fit the data with a summation of Voigt functions as these functions represent a convolution of Gaussian and Lorentzian line shapes, have a sound theoretical basis, and are well-suited to analysing spectroscopic absorption bands in which both lifetime broadening (e.g. due to spin-lattice relaxation) as well as Doppler, instrumental, and proximity line broadening are present to varying extents. This requires that the derivative ESR spectrum be fit in its integrated form (i.e. absorption spectrum, Figure 7a). In systems with rhombic $g$-tensors and no hyperfine coupling [e.g. low-spin Fe(III)] spectral deconvolution of the absorption trace is straightforward; the situation is, however, more complex in the case of low-spin $\mathrm{Mn}$ (II) due to each $g$-tensor component affording six absorption lines.

Given the above limitations expected for spectral deconvolution of the ESR absorption spectrum of a low-spin $\mathrm{Mn}(\mathrm{II})$ ion, precise location of $g_{\mathrm{y}}$ is nevertheless straightforward and simply achieved using $H_{\max }$ for the most intense component peak (3352 G) in the absorption spectrum (Figure 7a). Location of $g_{\mathrm{x}}$ and $g_{\mathrm{z}}$ is more difficult especially since the Voigt functions themselves are of variable band width and, in some cases, represent more than one overlapped peak. For $g_{z}$, the position of this tensor component is expected to be at the centre of gravity of the six independent equal-intensity lines into which the signal splits by virtue of hyperfine coupling to ${ }^{55} \mathrm{Mn}$. Only the three low-field hyperfine lines are in fact easily discerned. That said, the experimental anisotropic hyperfine coupling constant $A_{1}(115 \mathrm{G})$ may be used to locate $g_{z}$ since it is at precisely $2.5 A_{1}$ to higher magnetic field from the lowest-field line in the spectrum. Unfortunately locating $g_{\mathrm{x}}$ is significantly more problematic. Our best estimate using an analysis of the Voigt components in conjunction with the value of $A_{3}$ measured as indicated in Figure $7 \mathrm{~b}$ places $g_{\mathrm{x}}$ at $3428 \mathrm{G}$ (i.e., $g_{\mathrm{x}}=1.975$ ). From the Voigt functions in Figure $7 \mathrm{a}$, the anisotropic hyperfine coupling constants $A_{2}$ and $A_{3}$ measure 33 and $43 \mathrm{G}$, respectively. Note that measurement of $A_{3}$ from either the absorption or derivative spectrum is complicated somewhat by the fact that the peak expected between the indicted pair of lines is unresolved (as a result of overlap). (The spacing $2 A_{3}$ is, however, wellresolved and simple to measure.)

While useful, peak deconvolution of the ESR absorption spectrum is subject to significant uncertainty, particularly in the lower magnetic field range, contingent upon the lower intensity of the spectral envelope. The estimate of $A_{1}$ in Figure 7a [82(23) G] is therefore the least accurate of the three hyperefine coupling constantsin contrast to the situation when analyzing the first derivative of the spectral envelope. We therefore feel that for [3a] $\left[\mathrm{PF}_{6}\right]$ it is not only practically sound, but indeed preferable, to use the value of $A_{1}$ determined from analysis of the derivative trace (i.e. $A_{1}=115 \mathrm{G}$, Figure $7 \mathrm{~b}$ ).

A key question that emerged during analysis of the ESR spectrum of [3a] $\left[\mathrm{PF}_{6}\right]$ concerned assignment of the $g$ - 
tensor components as $g_{\mathrm{x}}, g_{\mathrm{y}}$, or $g_{\mathrm{z}}$. Experimental assignment of the $g$-tensor components requires determination of the tensor axes relative to the molecular framework, which requires a large face-indexed crystal, the X-ray crystal structure, and analysis of the ESR spectrum as a function of the orientation of the crystal in the applied magnetic field. In the absence of a suitable single crystal, we resorted to calculating the $g$-tensor and anisotropic spin-dipole couplings for $3 a^{\circ+}$ using a suitable hybrid DFT functional and several basis sets both in vacuo and in a $\mathrm{CH}_{2} \mathrm{Cl}_{2}$ solvent continuum. The $g$-values calculated with the all-electron basis set $6-311 \mathrm{~g}(\mathrm{~d}, \mathrm{p})^{[31]}$ (Table 3 ) are remarkably independent of the presence or absence of diffuse functions or solvent and are in excellent agreement with the experimental values. Furthermore, the calculated $g$-shifts relative to the free electron $g$-value allow unambiguous assignment of the experimental $g$-values as depicted in Figure $7 \mathrm{~b}$. The $g$-values calculated using the effective core potential (ECP) basis set $\mathrm{SDD}^{[32]}$ are also in good agreement with the experimental values; only $g_{z}$ deviates by more than $20,000 \mathrm{ppm}$ from the experimental value. Because of the generally good precision in the simulation data we can determine the mean calculated $g$-values using all of the available data for $3 a^{*+}: g_{x}=$ $1.998(1), g_{\mathrm{y}}=2.03(1)$, and $g_{\mathrm{z}}=2.13(5)$.

Table 3. DFT-calculated parameters for $3 a^{\bullet+}$ as a function of basis set type. ${ }^{[a]}$

\begin{tabular}{|c|c|c|c|c|}
\hline & $\begin{array}{r}6-311+g(d, p) \\
\text { DCM PCM }\end{array}$ & $6-311+g(d, p)$ & $6-311 g(d, p)$ & SDD \\
\hline$g$-tensor $x$-shift & -4632.9 & -5018 & -4510.8 & -2850 \\
\hline$g$-tensor $y$-shift & 31090.6 & 31140 & 33090.8 & 9549.2 \\
\hline$g$-tensor z-shift & 149600.2 & 151317.5 & 148546.9 & 57350 \\
\hline$g_{\mathrm{x}}$ calc. & 1.998 & 1.997 & 1.998 & 1.999 \\
\hline$g_{\mathrm{y}}$ calc. & 2.033 & 2.033 & 2.035 & 2.012 \\
\hline$g_{z}$ calc. & 2.152 & 2.154 & 2.151 & 2.060 \\
\hline$g_{\text {iso }}$ calc. & 2.061 & 2.061 & 2.061 & 2.024 \\
\hline Spin density & 1.17 & 1.09 & 1.14 & 1.29 \\
\hline IFCC / G & -40.28 & -41.33 & -40.07 & -0.01 \\
\hline$A_{1} / \mathrm{G}$ & -71.104 & -77.409 & -76.83 & -75.29 \\
\hline$A_{2} / \mathrm{G}$ & 22.278 & 36.133 & 30.636 & 35.728 \\
\hline$A_{3} / \mathrm{G}$ & 48.826 & 41.276 & 46.194 & 39.565 \\
\hline $4 s$ & 0.357 & 0.353 & 0.346 & 0.318 \\
\hline $4 p x$ & 0.348 & 0.329 & 0.021 & 0.317 \\
\hline 4py & 0.356 & 0.342 & 0.024 & 0.324 \\
\hline
\end{tabular}

[a] Units and abbreviations: DCM PCM, dichloromethane polarization continuum model; $g$-shifts relative to $g_{\mathrm{e}}$ for the free electron are in ppm; spin (Mulliken) and electron densities (NBO 3.0 ${ }^{[33]}$ ) are given in electron charge units and are listed for the $\mathrm{Mn}(\mathrm{II})$ ion only; IFCC, isotropic Fermi contact coupling for $\mathrm{Mn} ; A_{n}$ are the anisotropic spin-dipole coupling constants for $\mathrm{Mn}$ (where $n$ is the principal axis system component). 
The unpaired spin densities on the $\mathrm{Mn}$ (II) ion of $3 \mathrm{a}^{\cdot+}$ range from 1.09-1.29 e depending on the basis set used and are consistent with the value of 1.21 e calculated at the B3LYP/def2-SVP level of theory (vide supra). The calculated anisotropic spin-dipole couplings in Table 3 vary somewhat more with the basis set and/or the presence of solvent. The mean calculated anisotropic spin-dipole coupling constants are: $A_{1}=-75(3) \mathrm{G}, A_{2}=31(6)$ $\mathrm{G}$, and $A_{3}=44(4) \mathrm{G}$. From the experimental ESR spectrum of $3 \mathrm{a}^{\circ+}$, we were able to reliably measure $A_{2}(33 \mathrm{G})$ and $A_{3}(43 \mathrm{G})$, but not $A_{1}$. The value of $A_{1}$ determined from the derivative trace $(115 \mathrm{G})$ clearly deviates significantly from the calculated value of $A_{1}$. That said, determination of $A_{1}$ from the Voigt functions below $3150 \mathrm{G}$ in Figure 7a yields an estimated mean $A_{1}$ value of $82(23) \mathrm{G}$-somewhat closer to the DFT-calculated value, but subject to substantial uncertainty. Significantly, the relative absolute magnitudes of the experimental and DFT-calculated hyperfine coupling constants follow the same order $\left(A_{2}<A_{3}<<\left|A_{1}\right|\right)$, which affirms the approach we have used for assignment of the experimental ESR spectrum of [3a] $\left[\mathrm{PF}_{6}\right]$.

Importantly, replacement of one of the three $\mathrm{CO}$ ligands in cymantrene, $\mathrm{Mn}(\mathrm{Cp})(\mathrm{CO})_{3}$, with a carbene ligand in the present case of $3 a^{\circ+}$ lowers the symmetry of the $g$-tensor from tetragonal to rhombic. A switch in the $g$-tensor anisotropy may thus be used to detect the substitution of a carbonyl ligand in $\mathrm{Mn}$ (II) cymantrene derivatives (at least for carbenes). With the exception of the rhombic $g$-tensor, the magnitudes of the key ESR spectral parameters for $3 a^{*+}$ are broadly in accord with the tetragonal $g$ - and $A$-tensor components reported previously for $\mathrm{Mn}\left(\mathrm{Cp}^{\gamma}\right)(\mathrm{CO})_{3}$ derivatives, where $\gamma$ is a substituent on the $\mathrm{Cp}$ ligand. ${ }^{[6]}$ These latter tricarbonyl complexes have $g$ and $A$-values in the following ranges: $\mathrm{g}_{\|} \sim 2.12-2.21, \mathrm{~g}_{\perp} \sim 2.01-2.08, A_{\|} \sim 65-79 \mathrm{G}$, and $A_{\perp} \sim 30-50 \mathrm{G} .{ }^{[6]}$

\section{Conclusion}

Mono- and biscarbene cymantrene derivatives $\left[\mathrm{Cp}(\mathrm{CO})_{2} \mathrm{Mn}^{\prime}=\mathrm{C}(\mathrm{OEt}) \mathrm{Ar}\right] \mathbf{1 a}(\mathrm{Ar}=\mathrm{Th}), \mathbf{2 a}(\mathrm{Ar}=\mathrm{Fu}), \mathbf{3 a}(\mathrm{Ar}=\mathrm{Fc})$ and $\left[\mathrm{Cp}(\mathrm{CO})_{2} \mathrm{Mn}^{\prime}=\mathrm{C}(\mathrm{OEt})-\mathrm{Ar}^{\prime}-(\mathrm{OEt}) \mathrm{C}=\mathrm{Mn}^{\prime}(\mathrm{CO})_{2} \mathrm{Cp}\right]$ with $\mathrm{Ar}^{\prime}=\mathrm{Th}^{\prime}(\mathbf{1 b}), \mathrm{Ar}^{\prime}=\mathrm{Fu}^{\prime}(\mathbf{2 b})$ and $\mathrm{Ar}^{\prime}=\mathrm{Fc}^{\prime}(\mathbf{1} \mathbf{b})$ were prepared via the classical Fischer route. Low-temperature chemical oxidation of $3 a$ with $\mathrm{AgPF}_{6}$ permitted isolation of transiently stable $\left[\mathrm{Cp}(\mathrm{CO})_{2} \mathrm{Mn}^{\prime \prime}=\mathrm{C}(\mathrm{OEt}) \mathrm{Fc}\right]\left[\mathrm{PF}_{6}\right],[3 \mathrm{a}]\left[\mathrm{PF}_{6}\right]$. From an FTIR study, the $>110 \mathrm{~cm}^{-1}$ shift of the carbonyl stretching frequencies for [3a] $\left[\mathrm{PF}_{6}\right]$ relative to neutral $3 a$ indicates that the oxidation is that of the metal carbonyl moiety, as opposed to $\mathrm{Fe}$ "IFe"II oxidation of the ferrocenyl substituent. An electrochemical study on 1-3 confirmed that $\mathrm{Mn}(\mathrm{I})$ is oxidized before the ferrocenyl group, and that both these oxidations involve one-electron transfer processes. Complex $\mathbf{3 b}$ showed clear splitting of the $\mathrm{Mn}(\mathrm{I})$ oxidation into "a" and " $\mathrm{b}$ " components but $\mathbf{1 b}$ and $\mathbf{2} \mathbf{b}$ did not. This is consistent with $\mathrm{Ar}^{\prime}=\mathrm{Fc}$ ' being more effective in transmitting electrostatic interactions between cymantrenyl moieties than $\mathrm{Ar}^{\prime}=\mathrm{Fu}^{\prime}$ or Th'. Poorly chemically reversible reduction of $\mathrm{Mn}=\mathrm{C}^{-}$to $^{-} \mathrm{Mn}^{\prime}-\mathrm{C} \bullet$ was observed at far negative potentials $\left(<-2.065 \mathrm{~V}\right.$ vs. $\left.\mathrm{FcH} / \mathrm{FcH}^{+}\right)$. DFT calculations showed that the mono- and biscarbene complexes containing one or two $\mathrm{Mn}(\mathrm{I})$ ions always undergo one-electron oxidation of manganese before the onset of ligand or ferrocene oxidation. This reflects localization of the HOMO on the $\mathrm{Mn}=\mathrm{C}$ group of the cymantrene unit. Our interpretation of the electrochemical and DFT data was tested experimentally using ESR spectroscopy to probe $\mathbf{3} \mathbf{a}^{\circ+}$ produced by direct chemical oxidation of 3a. The ESR spectrum revealed a rhombic $g$ tensor for an $S=1 / 2 \mathrm{Mn}(I I)$ ion with ${ }^{55} \mathrm{Mn}$ hyperfine coupling constants in accord with those observed for $\left[\mathrm{Mn}\left(\mathrm{Cp}^{\gamma}\right)(\mathrm{CO})_{3}\right]^{+}$derivatives. The rhombic $g$-tensor for $3 a^{\circ+}$ evidently reflects reduced symmetry at the metal centre consistent with replacement of one cymantrene $\mathrm{CO}$ ligand by the $\mathrm{Mn}=\mathrm{C}(\mathrm{OEt}) \mathrm{Fc}$ carbene moiety.

\section{Experimental Section}

General: All operations were carried out under an inert atmosphere of nitrogen or argon gas using standard Schlenk techniques. Solvents were dried by refluxing on sodium metal (hexane, tetrahydrofuran and diethylether) or over phosphorous pentoxide $\left(\mathrm{CH}_{2} \mathrm{Cl}_{2}\right)$ and then distilled under nitrogen prior to use. Chemicals were used 
without further purification unless stated otherwise. Triethyloxonium tetrafluoroborate $\left(\mathrm{Et}_{3} \mathrm{OBF}_{4}\right)$ was synthesized according to literature procedures. ${ }^{[16]}$ Purification with column chromatography was done using silica gel $60(0.0063-0.200 \mathrm{~mm})$ as stationary phase. A Bruker AVANCE 500 spectrometer was used for NMR recordings. ${ }^{1} \mathrm{H}$ NMR spectra were recorded at $500.139 \mathrm{MHz}$ and ${ }^{13} \mathrm{C}$ NMR spectra at $125.75 \mathrm{MHz}$. The signal of the solvent was used as reference: ${ }^{1} \mathrm{H} \mathrm{CDCl}_{3}$ at $7.24 \mathrm{ppm} ; \mathrm{C}_{6} \mathrm{D}_{6}$ at $7.16 \mathrm{ppm}$ and ${ }^{13} \mathrm{C} \mathrm{CDCl} 3$ at $77.00 \mathrm{ppm} ; \mathrm{C}_{6} \mathrm{D}_{6}$ at $128.06 \mathrm{ppm}$. IR spectra were recorded on a Perkin-Elmer Spectrum RXI FT-IR spectrophotometer in $\mathrm{CH}_{2} \mathrm{Cl}_{2}$ as solvent. Only the vibrational bands in the carbonyl-stretching region (ca. $1600-2200 \mathrm{~cm}^{-1}$ ) were recorded.

Synthesis: Synthesis and characterization of $\mathbf{1} b{ }^{[12 c]} \mathbf{3} a^{[12 b]}$ and $\mathbf{3} \mathbf{b}^{[12 b]}$ have been reported earlier. Novel complexes $\mathbf{1} \mathbf{a}, \mathbf{2} \mathbf{a}$ and $\mathbf{2} \mathbf{b}$ were prepared in an adapted version of a previously reported method. ${ }^{[24]}$

Synthesis of $\left[\mathrm{Cp}(\mathrm{CO})_{2} \mathrm{Mn}=\mathrm{C}(\mathrm{OEt}) \mathrm{Th}\right](\mathbf{1 a})$ and $\left[\mathrm{Cp}(\mathrm{CO})_{2} \mathrm{Mn}=\mathrm{C}(\mathrm{OEt}) \mathrm{Th}^{\prime}(\mathrm{OEt}) \mathrm{C}=\mathrm{Mn}(\mathrm{CO}){ }_{2} \mathrm{Cp}\right](\mathbf{1 b})$.

2-Bromothiophene ( $2 \mathrm{mmol}, 0.2 \mathrm{~mL}$ ) was dissolved in $30 \mathrm{~mL}$ thf and cooled to $-70^{\circ} \mathrm{C}$. One equivalent LDA (2 $\mathrm{mmol}$ ) was added and the solution stirred for 15 minutes at low temperature. $\mathrm{CpMn}(\mathrm{CO})_{3}(2 \mathrm{mmol}, 0.40 \mathrm{~g})$ was added in one portion and stirred for 15 minutes after which the cold bath was removed and the mixture allowed to stir for an additional $1 \mathrm{hr}$. The reaction mixture was then cooled to $-60{ }^{\circ} \mathrm{C}$ and $\mathrm{nBuLi}(1.5 \mathrm{M}, 2 \mathrm{mmol}, 1.3 \mathrm{~mL})$ was slowly added. After 30 minutes another equivalent of $\mathrm{CpMn}(\mathrm{CO})_{3}(2 \mathrm{mmol}, 0.40 \mathrm{~g})$ was added and allowed to stir for $15 \mathrm{~min}$ in the cold. The bath was removed and the mixture stirred for $1 \mathrm{hr}$ at room temperature. The solvent was changed to $\mathrm{CH}_{2} \mathrm{Cl}_{2}$ and the reaction cooled to $-40{ }^{\circ} \mathrm{C}$ after which 2 equivalents of $\mathrm{Et}_{3} \mathrm{OBF}_{4}$ with $10 \%$ excess $\left(4.4 \mathrm{mmol}\right.$ ) dissolved in $\mathrm{CH}_{2} \mathrm{Cl}_{2}$ was added. After $15 \mathrm{~min}$ in the cold bath the mixture was allowed to reach room temperature over an hour. Purification with column chromatography on silica and gradient elution starting with 1:4 $\mathrm{CH}_{2} \mathrm{Cl}_{2} /$ hexane solution afforded the ochre coloured monocarbene (1a) and the maroon coloured biscarbene (1) complexes.

For 1a: Yield 45\% (0.28g), dark yellow crystals. Anal. calcd. for $\mathrm{MnC}_{14} \mathrm{H}_{13} \mathrm{O}_{3} \mathrm{~S}$ (316.28), C:53.16, $\mathrm{H}: 4.15$; Found $\mathrm{C}: 53.18, \mathrm{H}: 4.16 .{ }^{1} \mathrm{H}$ NMR $\left(\mathrm{C}_{6} \mathrm{D}_{6}, \delta / \mathrm{ppm}\right): 7.80\left(\mathrm{br}, 1 \mathrm{H}, \mathrm{Th}-\mathrm{H}_{\alpha}\right), 6.93\left(\mathrm{br}, 1 \mathrm{H}, \mathrm{Th}-\mathrm{H}_{\mathrm{\gamma}}\right), 6.96\left(\mathrm{br}, 1 \mathrm{H}, \mathrm{Th}-\mathrm{H}_{\mathrm{B}}\right), 4.75(\mathrm{br}$, $\left.2 \mathrm{H}, \mathrm{CH}_{2}\right), 4.14(\mathrm{br}, 5 \mathrm{H}, \mathrm{Cp}), 1.19\left(\mathrm{br}, 3 \mathrm{H}, \mathrm{CH}_{3}\right) ;{ }^{13} \mathrm{C} \mathrm{NMR}\left(\mathrm{C}_{6} \mathrm{D}_{6}, \delta / \mathrm{ppm}\right): 319.46$ ( C carbene $\left._{2}\right), 231.19$ (CO), 156.74 $\left(\mathrm{Th}_{\mathrm{ipso}}\right), 136.60\left(\mathrm{Th}-\mathrm{C}_{\gamma}\right), 136.30\left(\mathrm{Th}-\mathrm{C}_{\alpha}\right), 130.78\left(\mathrm{Th}-\mathrm{C}_{\mathrm{B}}\right), 83.97(\mathrm{Cp}), 73.99\left(\mathrm{CH}_{2}\right), 15.11\left(\mathrm{CH}_{3}\right) . \mathrm{IR}\left(\mathrm{CH}_{2} \mathrm{Cl} 2, \mathrm{v}(\mathrm{CO}) / \mathrm{cm}^{-1}\right)$ : 1936, 1872.

Synthesis of $\left[\mathrm{Cp}(\mathrm{CO})_{2} \mathrm{Mn}=\mathrm{C}(\mathrm{OEt}) \mathrm{Fu}\right](\mathbf{2 a})$ and $\left[\mathrm{Cp}(\mathrm{CO})_{2} \mathrm{Mn}=\mathrm{C}(\mathrm{OEt}) \mathrm{Fu} \mathrm{\prime}^{\prime}(\mathrm{OEt}) \mathrm{C}=\mathrm{Mn}(\mathrm{CO})_{2} \mathrm{Cp}\right](\mathbf{2} \boldsymbol{b})$

Furan $(2.7 \mathrm{mmol}, 0.2 \mathrm{~mL})$ was dissolved in $50 \mathrm{~mL}$ thf and cooled to $-20{ }^{\circ} \mathrm{C}$. $\mathrm{nBuLi}(1.5 \mathrm{M}, 1.8 \mathrm{~mL})$ was added slowly to the stirring solution which was then left to react in the cold for $30 \mathrm{~min}$. It was then cooled further to $-40{ }^{\circ} \mathrm{C}$ and $\mathrm{CpMn}(\mathrm{CO})_{3}$ ( $2.7 \mathrm{mmol}, 0.55 \mathrm{~g}$ ) was added in one portion. The cold bath was removed after $15 \mathrm{~min}$ and the mixture left to stir at room temperature for $1 \mathrm{hr}$. The reaction was cooled again to $-78^{\circ} \mathrm{C}$ and LDA $(0.18 \mathrm{M}, 15$ $\mathrm{mL}$ ) was added and the reaction stirred for $1 \mathrm{hr}$. It was warmed to $-40{ }^{\circ} \mathrm{C}$ and $\mathrm{CpMn}(\mathrm{CO})_{3}(2.7 \mathrm{mmol}, 0.55 \mathrm{~g})$ was added. After stirring for $1 \mathrm{hr}$ at room temperature the acylate was quenched with $\mathrm{Et}_{3} \mathrm{OBF}_{4}(0.54 \mathrm{M}, 12 \mathrm{~mL})$ at -20 ${ }^{\circ} \mathrm{C}$ in $\mathrm{CH}_{2} \mathrm{Cl}_{2}$ and stirred for another hour at room temperature. Purification was performed by column chromatography on silica and gradient elution starting with $1: 4 \mathrm{CH}_{2} \mathrm{Cl}_{2} /$ hexane solution. The brown coloured monocarbene (2a) and the maroon coloured biscarbene (2b) complexes were collected. 
For 2a: Yield 56\% (0.48g), dark yellow crystals. Anal. calcd. for $\mathrm{MnC}_{14} \mathrm{H}_{13} \mathrm{O}_{4}$ (316.21), C:53.16, $\mathrm{H}: 4.15$; Found $\mathrm{C}: 53.21, \mathrm{H}: 4.20 .{ }^{1} \mathrm{H}$ NMR $\left(\mathrm{C}_{6} \mathrm{D}_{6}, \delta / \mathrm{ppm}\right): 6.71\left(\mathrm{br}, 2 \mathrm{H}, \mathrm{Fu}-\mathrm{H}_{\gamma}\right), 6.71\left(\mathrm{br}, 1 \mathrm{H}, \mathrm{Fu}-\mathrm{H}_{\alpha}\right), 5.97\left(\mathrm{br}, 1 \mathrm{H}, \mathrm{Fu}-\mathrm{H}_{\mathrm{B}}\right), 4.75(\mathrm{br}$, $\left.2 \mathrm{H}, \mathrm{CH}_{2}\right), 4.38$ (br, 5H, Cp), 1.21 (br, 3H, $\left.\mathrm{CH}_{3}\right) ;{ }^{13} \mathrm{C} \mathrm{NMR}\left(\mathrm{C}_{6} \mathrm{D}_{6}, \delta / \mathrm{ppm}\right): 309.31$ ( $\left.\mathrm{C}_{\text {carbene }}\right), 232.22$ (CO), 164.49 $\left(\mathrm{Fu}_{\text {ipso }}\right), 145.20\left(\mathrm{Th}_{-} \mathrm{C}_{\gamma}\right), 112.03\left(\mathrm{Fu}-\mathrm{C}_{\alpha}\right), 111.50\left(\mathrm{Fu}-\mathrm{C}_{\mathrm{B}}\right), 84.27(\mathrm{Cp}), 73.20\left(\mathrm{CH}_{2}\right), 15.27\left(\mathrm{CH}_{3}\right) . \mathrm{IR}\left(\mathrm{CH}_{2} \mathrm{Cl}, \mathrm{v}(\mathrm{CO}) / \mathrm{cm}^{-1}\right)$ : 1942, 1876.

For 2b: Yield 32\% (0.44g), maroon crystals. Anal. calcd. for $\mathrm{Mn}_{2} \mathrm{C}_{24} \mathrm{H}_{22} \mathrm{O}_{8}$ (548.38), C:52.56, $\mathrm{H}: 4.05$; Found C:52.59, $\mathrm{H}: 4.07 .{ }^{1} \mathrm{H}$ NMR $\left(\mathrm{C}_{6} \mathrm{D}_{6}, \delta / \mathrm{ppm}\right): 6.84(\mathrm{br}, 2 \mathrm{H}, \mathrm{Fu}-\mathrm{H}), 4.77\left(\mathrm{br}, 4 \mathrm{H}, \mathrm{CH}_{2}\right), 4.41(\mathrm{br}, 10 \mathrm{H}, \mathrm{Cp}), 1.25\left(\mathrm{br}, 6 \mathrm{H}, \mathrm{CH}_{3}\right) ;{ }^{13} \mathrm{C}$ $\operatorname{NMR}\left(\mathrm{C}_{6} \mathrm{D}_{6}, \delta / \mathrm{ppm}\right): 306.82\left(\mathrm{C}_{\text {carbene }}\right), 232.32(\mathrm{CO}), 161.57\left(\mathrm{Fu}_{\text {ipso }}\right), 116.57(\mathrm{Fu}), 85.84(\mathrm{Cp}), 73.35\left(\mathrm{CH}_{2}\right), 15.40\left(\mathrm{CH}_{3}\right)$. IR $\left(\mathrm{CH}_{2} \mathrm{Cl}, \mathrm{v}(\mathrm{CO}) / \mathrm{cm}^{-1}\right): 1935,1886$.

\section{Synthesis of $\left.\left[\mathrm{Cp}(\mathrm{CO})_{2} \mathrm{Mn}=\mathrm{C}(\mathrm{OEt}) \mathrm{Fc}\right]\left[\mathrm{PF} \mathrm{F}_{6}\right]\left([3 \mathrm{Ba}] \mathrm{PF} \mathrm{F}_{6}\right]\right)$.}

Compound 3a (0.006g, $0.01 \mathrm{mmol})$ was dissolved in $\mathrm{CH}_{2} \mathrm{Cl}_{2}$ and cooled to $-35{ }^{\circ} \mathrm{C}$. $\mathrm{AgPF}_{6}(0.003 \mathrm{~g}, 0.01 \mathrm{mmol})$ was added in one portion after which the colour changed rapidly from dark red to brown. The solution was filtered using cannula filtration.

For [3a][PF 6 ]: Yield 78\% (0.006g), dark brown salt. IR $\left(\mathrm{CH}_{2} \mathrm{Cl}_{2}, \mathrm{v}(\mathrm{CO}) / \mathrm{cm}^{-1}\right): 2042,1978$.

Electrochemistry: Cyclic voltammograms (CV's), square wave voltammograms (SW's) and linear sweep voltammograms (LSV's) were recorded on a Princeton Applied Research PARSTAT 2273 voltammograph running PowerSuite (Version 2.58). All experiments were performed in a dry three-electrode cell. A platinum wire was used as auxiliary electrode while a glassy carbon working electrode (surface area $3.14 \mathrm{~mm}^{2}$ ) was utilized after polishing on a Buhler polishing mat first with 1 micron and then with 1/4 micron diamond paste. A silver wire was used as pseudo internal reference under an argon atmosphere inside an M Braun Lab Master SP glovebox filled with high purity argon $\left(\mathrm{H}_{2} \mathrm{O}\right.$ and $\left.\mathrm{O}_{2}<5 \mathrm{ppm}\right)$. All electrode potentials are reported using the potential of the ferrocene/ferrocenium redox couple $\left[\mathrm{FcH} / \mathrm{FcH}^{+}\right]\left(\mathrm{FcH}=\left(\eta^{5}-\mathrm{C}_{5} \mathrm{H}_{5}\right)_{2} \mathrm{Fe}, \mathrm{E}^{\circ \prime}=0.00 \mathrm{~V}\right)$ as reference. ${ }^{[34]}$ However, decamethyl ferrocene, $\mathrm{Fc}^{*}$, was used as internal standard to prevent signal overlap with the ferrocenyl of 3. Decamethylferrocene has a potential of $-550 \mathrm{mV}$ versus free ferrocene with $\Delta \mathrm{E}=72 \mathrm{mV}$ and $\mathrm{i}_{\mathrm{pc}} / \mathrm{i}_{\mathrm{pa}}=0.99$ under the conditions employed. ${ }^{[26]}$ Analyte solutions $\left(0.5 \mathrm{mmol} \mathrm{dm}{ }^{-3}\right)$ were prepared in dry $\mathrm{CH}_{2} \mathrm{Cl}_{2}$ in the presence of 0.1 $\mathrm{mol} \mathrm{dm}{ }^{-3}\left[\left({ }^{n} \mathrm{Bu}_{4}\right) \mathrm{N}\right]\left[\mathrm{PF}_{6}\right]$. Analyses were performed at $20^{\circ} \mathrm{C}$. Data were exported to a spread sheet program for manipulation and diagram preparation.

ESR Spectroscopy: The cation radical [3a] $\left.\mathrm{PF}_{6}\right]$ was generated as follows for ESR spectroscopy. Solid compound $3 a$ $(0.060 \mathrm{~g}, 0.10 \mathrm{mmol})$ and solid $\mathrm{AgPF}_{6}(0.030 \mathrm{~g}, 0.10 \mathrm{mmol})$ were placed together in a dry Schlenk tube under nitrogen at $-41^{\circ} \mathrm{C}$ in an acetonitrile/liquid nitrogen slush bath. After thermal equilibration, $10 \mathrm{~mL}$ of dry $\mathrm{CH}_{2} \mathrm{Cl}_{2}$ that had been pre-cooled to $-41^{\circ} \mathrm{C}$ was added to the solids via cannula transfer from a reservoir flask under nitrogen. The solution immediately changed from orange-brown to deep red and was mixed by swirling for ca. 6 min at $-41^{\circ} \mathrm{C}$ before transferring a ca. $600-\mu \mathrm{L}$ aliquot of the reaction mixture by cannula filtration into a gas-tight ESR tube suspended in the slush bath at $-41^{\circ} \mathrm{C}$. The sample aliquot was immediately flash-frozen in liquid nitrogen and then transferred to a liquid nitrogen-containing quartz finger dewar mounted in the sample slot of the microwave resonator of a Bruker EMX-plus X-band ESR spectrometer operating at a frequency of 9.421260 $\mathrm{GHz}$. The final spectrum was obtained from 12 scans over the spectral range 2700-3900 $\mathrm{G}$ using the data acquisition parameters indicated in Figure 7. The spectral data in derivative mode were first filtered (boxcar averaging with a 7 point window and $9^{\text {th }}$ order polynomial filter) and then resolution-enhanced (line-broadening 
function $=0.200 \mathrm{G}$ ) for the final plot. The ESR absorption spectrum (raw data) was deconvoluted into a series of constituent Voigt functions using FitYk $0.9 .8^{[35]}$ in order to facilitate $g$-value assignments. The fit parameters are given in the Supporting Information.

Molecular simulations: Geometry optimizations without symmetry constraints were carried out using the Gaussian09 suite of programs. ${ }^{[36]}$ Electron correlation was partially taken into account using the hybrid functional denoted as B3LYP (and UB3LYP for radical cations and open-shell species) ${ }^{[37]}$ in combination with double- $\zeta$ quality plus polarization def2-SVP ${ }^{[38]}$ basis set for all atoms (this level is denoted B3LYP/def2-SVP). Calculation of the vibrational frequencies ${ }^{[39]}$ at the optimized geometries showed that the compounds are minima on the potential energy surface. The $\mathrm{AIM}^{[40]}$ results described in this work correspond to calculations performed at the B3LYP/def2-SVP level on the optimized geometry of $2 \mathrm{a}^{+2}$. The topology of the electron density was studied using the AIMAll program package. ${ }^{[41]}$ DFT simulations for analysis of the ESR spectrum of $3 a^{0+}$, specifically determination of the $g$ - and $A$-tensors, were performed with an unrestricted wave function using the full HeydScuseria-Ernzerhof hybrid functional HSEH1PBE ${ }^{[42]}$ and three basis sets: the effective core potential basis set $\mathrm{SDD}^{[32]}$ and the all-electron basis sets $6-311 \mathrm{~g}(\mathrm{~d}, \mathrm{p})^{[31]}$ or $6-311+\mathrm{g}(\mathrm{d}, \mathrm{p})$. We also determined the electronic structure of $3 a^{\circ+}$ in $\mathrm{CH}_{2} \mathrm{Cl}_{2}$ (polarization continuum model, $\mathrm{PCM}$ ). The geometries of all structures were fully optimized; no negative eigenvalues were calculated in any of the post-optimization frequency jobs.

\section{Acknowledgements}

This work is supported by the National Research Foundation (NRF) of South Africa, (D.I.B., Grant number 76226; J.C.S., Grant number 81829). I. F. acknowledges the Spanish MICINN and CAM (Grants CTQ2010-20714-CO201/BQU, Consolider-Ingenio 2010, CSD2007-00006, S2009/PPQ-1634). O.Q.M. acknowledges financial support from the University of KwaZulu-Natal and the NRF.

\section{References}

[1] a) L. Cuffe, R. D. A. Hudson, J. F. Gallagher, S. Jennings, C. J. McAdam, R. B. T. Connelly, A. R. Manning, B. H. Robinson, J. Simpson, Organometallics, 2005, 24, 2051-2060; b) S. Warren, T. McCormac, E. Dempsey, Bioelectrochemistry, 2005, 67, 23-35; c) A. D. Ryabov, Ad. Inorg. Chem., 2004, 55, 201-269; d) K. C. Kemp, E. Fourie, J. Conradie, J. C. Swarts, J. C. Organometallics, 2008, 27, 353-362; e) P. D. Beer, E. Hayes, J. Coord. Chem., 2003, 240, 167-189; (f) A. Chaubey, B. D. Malhotra, Biosens. Bioelectron., 2002, 17, 441-456.

[2] a) R. F. Shago, J. C. Swarts, E. Kreft, C. E. J. Van Rensburg, Anticancer Res. 2007, 27, 3431-3433; b) C. E. J. Van Rensburg, E. Kreft, J. C. Swarts, S. R. Dalrymple, D. M. Macdonald, M. W. Cooke, M. A. S. Aquino, Anticancer Res. 2002, 22, 889892; c) A. Gross, N. Hüsken, J. Schur, L. Raszeja, I. Ott, N. Metzler-Nolte, Bioconjugate Chemistry, 2012, 23, 1764-1774; d) J. C. Swarts, T. G. Vosloo, S. J. Cronje, W. C. Du Plessis, C. E. J. Van Rensburg, E. Kreft, J. E. Van Lier, Anticancer Res. 2008, 28, 2781-2784; e) I. Ott, K. Kowalski, R. Gust, J. Maurer, P. Mücke, R. F. Winter, Bioorg. Med. Chem. Lett. 2010, 20, 866-869.

[3] A. R. Pike, L. C. Ryder, B. R. Horrocks, W. Clegg, B.A. Connolly, A. Houlton, Chem. Eur. J. 2004, 11, 344-353.

[4] F. Spanig, C. Kolvacs, F. Hauke, K. Ohlubo, F. Fukuzumi, D. M. Guldi, A. Hirsch, J. Am. Chem. Soc. 2009, 131, 8180-8195.

[5] a) S. D. Lepore, A. Khoram, D. C. Bromfield, P. Cohn, V. Jairaj, M. A. Silvestri, J. Org. Chem., 2005, 70, 7443-7446; b) Z. Zhang, S. D. Lepore, Tetrahedr. Lett., 2002, 43, 7357-7360; c) H. Gradén, N. Kann, Curr. Org. Chem., 2005, 9, 733-763; d) L. M. Dorozhkin, V. A. Nefedov, A. G. Sabelnikov, V. G. Sevastjanov, Sens. Actuators B., 2004, B99, 568-570.

[6] D. R. Laws, D. Chong, K. Nash, A. L. Rheingold, W. E. Geiger, J. Am. Chem. Soc., 2008, 130, 9859-9870.

[7] a) M. Hromadova, M. Salmain, N. Fischer-Durand, L. Pospisil, G. Jaouen, Langmuir, 2006, 22, 506-511; b) M. Hromadoca, M. Salmain, R. Sokolova, L. Pospisil, G. Jaouen, J. Organomet. Chem., 2003, 668, 17-24. 
[8] a) C. N. Field, J. C. Green, A. G. J. Moody, M. R. F. Siggel, Chem. Phys., 1996, 206, 211-223; b) D. C. Calabro, D. L. Lichtenberger, J. Am. Chem. Soc., 1981, 103, 6846-6852; c) D. L. Lichtenberger, R. F. Fenske, J. Am. Chem. Soc., 1976, 98, 50-63.

[9] C. G. Atwood, W. E. Geiger, T. E. Bitterwolf, J. Electroanal. Chem., 1995, 397, 279-285.

[10] Selected recent reviews on the chemistry of group 6 Fischer carbene complexes: a) M. A. Sierra, I. Fernández, F. P. Cossío, Chem. Commun. 2008, 4671; b) K. H. Dötz, J. Stendel, Chem. Rev. 2009, 109, 3227; c) J. W. Herndon, Coord. Chem. Rev. 2010, 254, 103; d) M. A. Fernández-Rodríguez, P. García-García, E. Aguilar, Chem. Commun. 2010, 46, 7670; e) I. Fernández, F. P. Cossío, M. A. Sierra, Acc. Chem. Res. 2011, 44, 479; f) D. I. Bezuidenhout, S. Lotz, D.C. Liles, B. van der Westhuizen, Coord. Chem. Rev., 2012, 256, 479-524.

[11] a) I. Hoskovcová, R. Svěřinová, J. Roháčová, D. Dvořák, T. Tobrman, S. Záliš, J. Ludvík, Electr. Chim. Acta, 2011, 56, 68536859; b) I. Hoskovcová, J. Roháčová, D. Dvořák, T. Tobrman, S. Záliš, R. Svěřinová, J. Ludvík,Electr. Chim. Acta, 2010, 55, 8341-8351.

[12] a) M. Landman, W. Barnard, P. H. van Rooyen, D. C. Liles, J. Mol. Struct., 2012, 1021, 76-83; b) D. I. Bezuidenhout, S. Lotz, M. Landman, D. C. Liles, Inorg. Chem., 2011, 50(4), 1521-1533; c) Y. M. Terblans, M. H. Roos, S. Lotz, J. Organomet. Chem., 1998, 566(1-2), 133-142; d) E. O. Fischer, V. N. Postnov, F. R. Kreissl, J. Organomet. Chem., 1982, 231(4), C73C77.

[13] A related electrochemical study on an Fe-NHC complex has been reported, see: L. Mercs, G. Labat, A. Neels, A. Ehlers, M. Albrecht, Organometallics, 2006, 25, 5648-5656.

[14] D. I. Bezuidenhout, W. Barnard, B. van der Westhuizen, E. van der Watt, D. C. Liles, Dalton Trans., 2011, 40, 6711-6721.

[15] E. O. Fischer, A. Maasböl, Angew. Chem.Int. Ed. Engl.1964, 3(8), 580-581.

[16] H. Meerwin, Org. Synth., 1966, 46, 113-115.

[17] N. G. Connolley, W. E. Geiger, Chem. Rev., 1996, 96, 877-910.

[18] Compound $\mathbf{2 b}$ was prepared and spectroscopically characterized. However, the instability of $\mathbf{2 b}$ with regards to atmospheric decomposition precluded it from the electrochemical studies, and no usable CV could be recorded.

[19] a) S. Lotz, C. Crause, A. J. Olivier, D. C. Liles, H. Gorls, M. Landman, D. I. Bezuidenhout, Dalton Trans. 2009, 697-710; b) M. Landman, J. Ramontja, M van Staden, D. I. Bezuidenhout, P. H. van Rooyen, D. C. Liles, S. Lotz, Inorg. Chim. Acta 2010, 363, 705-717; c) G. M. Chu, I. Fernández, M. A. Sierra, Chem. Eur. J. 2013, 19, 5899-5908; d) E. Pretch, J. Seibl, T. Clerc, W. Simon, Tables for Spectral Data for Structure Determination of Organic Compounds, 2nd ed.; Springer-Verlag: Berlin, Germany, 1989.

[20] a) P. S. Braterman, Metal Carbonyl Spectra, Academic Press Inc., London, 1975, p. 68; b) D. M. Adams, Metal-Ligand and Related Vibrations, Edward Arnold Publishers Ltd, London, 1967, p. 98.

[21] I. M. Alecu, J. Zheng, Y. Zhao, D. G. Truhlar, J. Chem. Theory Comput., 2010, 6, 2872-2887.

[22] a) B. Van der Westhuizen, P. J. Swarts, I. Strydom, D. C. Liles, I. Fernández, J. C. Swarts, D. I. Bezuidenhout, Dalton Trans. 2013, 42, 5367-5378; b) B. Van der Westhuizen, P. J. Swarts, L. M. van Jaarsveld, D. C. Liles, U. Siegert, J. C. Swarts, I. Fernández, D. I. Bezuidenhout, Inorg. Chem. 2013, 52, 6674-6684.

[23] D. I. Bezuidenhout, I. Fernández, B. Van der Westhuizen,, P. J. Swarts, J. C. Swarts, Organometallics, 2013, 32, 73347344.

[24] See computational details.

[25] a) D. A. Valyaev, R. Nrousses, N. Lugan, I. Fernández, M. A. Sierra, Chem. Eur. J. 2011, 17(24), 6602-6605; b) N. Lugan, I. Fernández, R. Brousses, D. A. Valyaev, G. Lavigne, N. A. Ustynyuk, Dalton. Trans., 2013, 42(4), 898-901.

[26] Leading references describing the electrochemical activity and behaviour of ferrocene and decamethylferrocene in a multitude of organic solvents are: a) I. Noviandri, K. N. Brown, D. S. Fleming, P. T. Gulyas, P. A. Lay, A. F. Masters and L. Phillips, J. Phys. Chem. B, 1999, 103, 6713-6722; b) N. G. Connelly and W. E. Geiger, Chem. Rev., 1996, 96, 877-910; c) J. Ruiz and D. Astruc, C. R. Acad. Sci., Ser. Ilc: Chim., 1998, 1, 21-27; d) R. J. Aranzaes, M. C. Daniel and D. Astruc, Can. J. Chem., 2006, 84, 288-299; e) E. Fourie, J. C. Swarts, I. Chambrier, M. J. Cook, Dalton Trans., 2009, 1145-1154.

[27] N. G. Connelly, W. E. Geiger, Adv. Organomet. Chem., 1984, 23, 49.

[28] a) H. J. Gericke, N. I. Barnard, E. Erasmus, J. C. Swarts, M. J. Cook, M. A. S. Aquino, Inorg. Chim. Acta, 2010, 363, 22222232; b) D. H. Evans, K. M. O’Connell, R. A. Peterson, M. J. Kelly, J. Chem. Educ., 1983, 60, 290-293; c) P. T. Kissinger, W. R. Heineman, J. Chem. Educ. 1983, 60, 702-706. d) J. J. Van Benschoten, J. Y. Lewis, W. R. Heineman, J. Chem. Educ., 1983, 60, 772-776; e) G. A. Mobbott, J. Chem. Educ., 1983, 60, 697-702; f) M. J. Cook, I. Chambrier, G. F. White, E. Fourie, J. C. Swarts, Dalton Trans. 2009, 1136-1144. 
[29] M. Lein, Coord. Chem. Rev. 2009, 253, 625-634.

[30] a) K. L. Letchworth, D. C. Benner, J. Quant. Spectr. Radiative Transfer, 2007, 107, 173-192; b) B. H. Armstrong, J. Quant. Spectr. Radiative Transfer, 1967, 7, 61-88.

[31] A. D. McLean, G. S. Chandler, J. Chem. Phys., 1980, 72, 5639-5648.

[32] P. Fuentealba, H. Preuss, H. Stoll, L. Von Szentpály, Chem. Phys. Lett. 1982, 89, 418-422.

[33] A. E. Reed, R. B. Weinstock, F. Weinhold. J. Chem. Phys. 1985, 83, 735-746.

[34] a) G. Gritzner and J. Kuta, Pure Appl. Chem., 1984, 56, 461-466; b) R. R. Gagne, C. A. Koval and G. C. Lisensky, Inorg.Chem., 1980, 19, 2854-2855.

[35] Wojdyr, M. J. Appl. Crystallogr. 2010, 43, 1126-1128.

[36] M. J. Frisch, G. W. Trucks, H. B. Schlegel, G. E. Scuseria, M. A. Robb, J. R. Cheeseman, G. Scalmani, V. Barone, B. Mennucci, G. A. Petersson, H. Nakatsuji, M. Caricato, X. Li, H. P. Hratchian, A. F. Izmaylov, J. Bloino, G. Zheng, J. L. Sonnenberg, M. Hada, M. Ehara, K. Toyota, R. Fukuda, J. Hasegawa, M. Ishida, T. Nakajima, Y. Honda, O. Kitao, H. Nakai, T. Vreven, J. A. Montgomery Jr., J. E. Peralta, F. Ogliaro, M. Bearpark, J. J. Heyd, E. Brothers, K. N. Kudin, V. N. Staroverov, R. Kobayashi, J. Normand, K. Raghavachari, A. Rendell, J. C. Burant, S. S. Iyengar, J. Tomasi, M. Cossi, N. Rega, J. M. Millam, M. Klene, J. E. Knox, J. B. Cross, V. Bakken, C. Adamo, J. Jaramillo, R. Gomperts, R. E. Stratmann, O. Yazyev, A. J. Austin, R. Cammi, C. Pomelli, J. W. Ochterski, R. L. Martin, K. Morokuma, V. G. Zakrzewski, G. A. Voth, P. Salvador, J. J. Dannenberg, S. Dapprich, A. D. Daniels, Ö. Farkas, J. B. Foresman, J. V. Ortiz, J. Cioslowski and D. J. Fox, Gaussian 09, Revision B.1, Gaussian, Inc., Wallingford, CT, 2009.

[37] a) A. D. Becke, J. Chem. Phys., 1993, 98, 5648; b) C. Lee, W. Yang and R. G. Parr, Phys. Rev. B: Condens. Matter, 1988, 37, 785-789.

[38] F. Weigend, R. Ahlrichs, Phys. Chem. Chem. Phys., 2005, 7, 3297-3305.

[39] J. W. Mclver and A. K. Komornicki, J. Am. Chem. Soc., 1972, 94, 2625-2633.

[40] R. F. W. Bader, Atoms in Molecules - A Quatum Theory, Oxford University Press, Oxford, 1990.

[41] T. A. Keith, AIMAll, 2010, http://tkgristmill.com]

[42] J. Heyd, G. Scuseria, J. Chem. Phys. 2004, 121, 1187-1192. 
Layout 1:

\section{Isolating a carbene radical cation}

Daniela I. Bezuidenhout, ${ }^{[a] *}$

Belinda van der Westhuizen, ${ }^{[a]}$

Pieter J. Swarts, ${ }^{[b]}$ Teshica

Chatturgoon, ${ }^{[c]}$ Orde $Q$.

Munro, ${ }^{[c]}$ Israel Fernández, ${ }^{[d] *}$

and Jannie C. Swarts ${ }^{[b] *}$

Redox behaviour of

cymantrenyl Fischer carbene

complexes in designing

organometallic multi-tags
An electrochemical and computational elucidation of the redox behaviour of Fischer carbene derivatised cymantrene complexes. The isolation of the chemically oxidised radical cation of the ferrocenylcarbene cymantrene complex was achieved, and could be characterised by FTIR and ESR spectroscopy.

Keywords: Fischer carbenes $\bullet$ organometallic multi-tags $\bullet$ electrochemistry $\bullet$ manganese(I) $\bullet$ DFT calculations $\bullet$ ESR spectroscopy 


\section{Schemes and Figures}

(a)

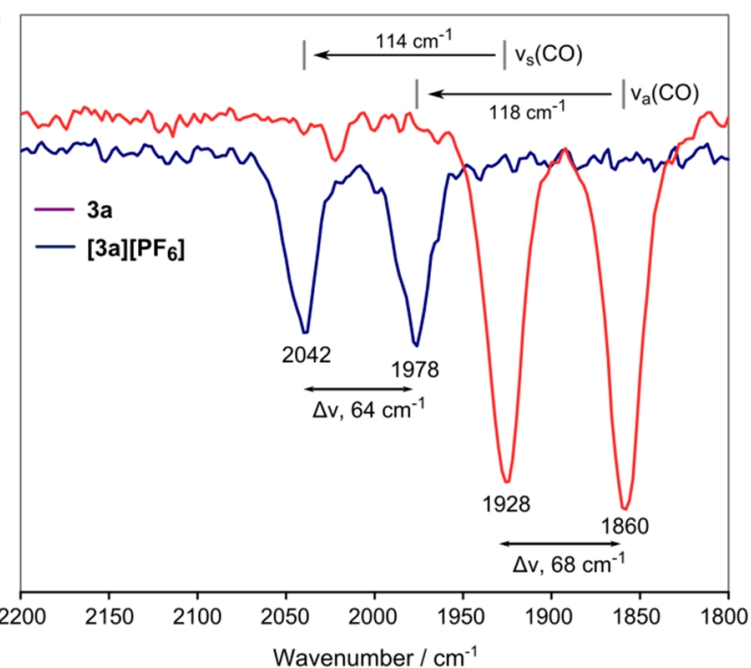

(b)

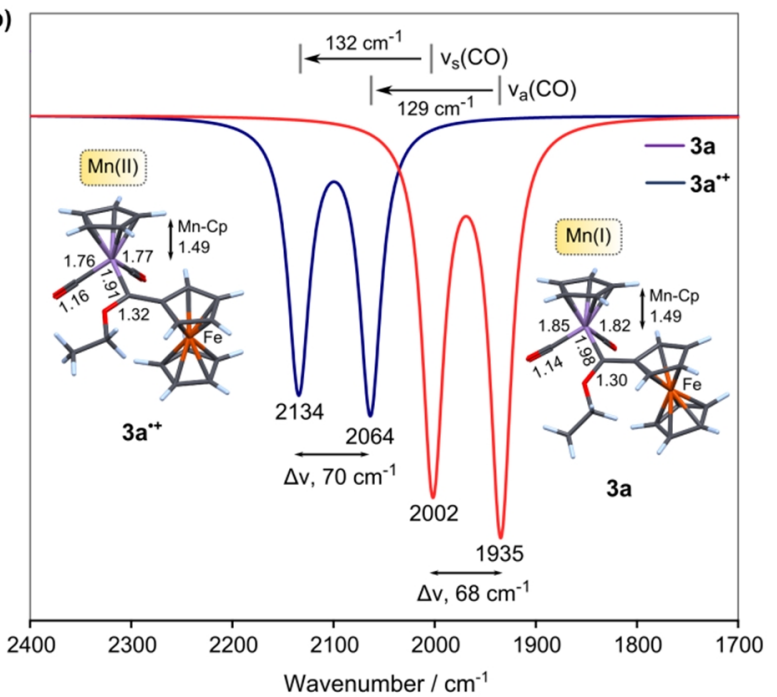

Figure 1. (a) Carbonyl region FTIR spectra of neutral $\mathbf{3 a}$ and the oxidized species $[3 a]\left[\mathbf{P F}_{6}\right]$ in $\mathrm{CH}_{2} \mathrm{Cl}_{2}$. The antisymmetric CO stretching mode $\left(v_{a}\right)$ is at a lower wavenumber than the symmetric mode $\left(v_{s}\right)$ in each oxidation state. (b) DFT-calculated IR spectra (HWHM line width, $13 \mathrm{~cm}^{-1}$ ) for $\mathbf{3 a}$ and $3 a^{\bullet+}$ at the HSEH1PBE/6-311+g(d,p) level of theory in $\mathrm{CH}_{2} \mathrm{Cl}_{2}$ solvent (polarization continuum model, PCM). Key bond distances ( $\AA$ ) for the two complexes are indicated along with band shifts and splittings for comparison with the experimental spectrum. 


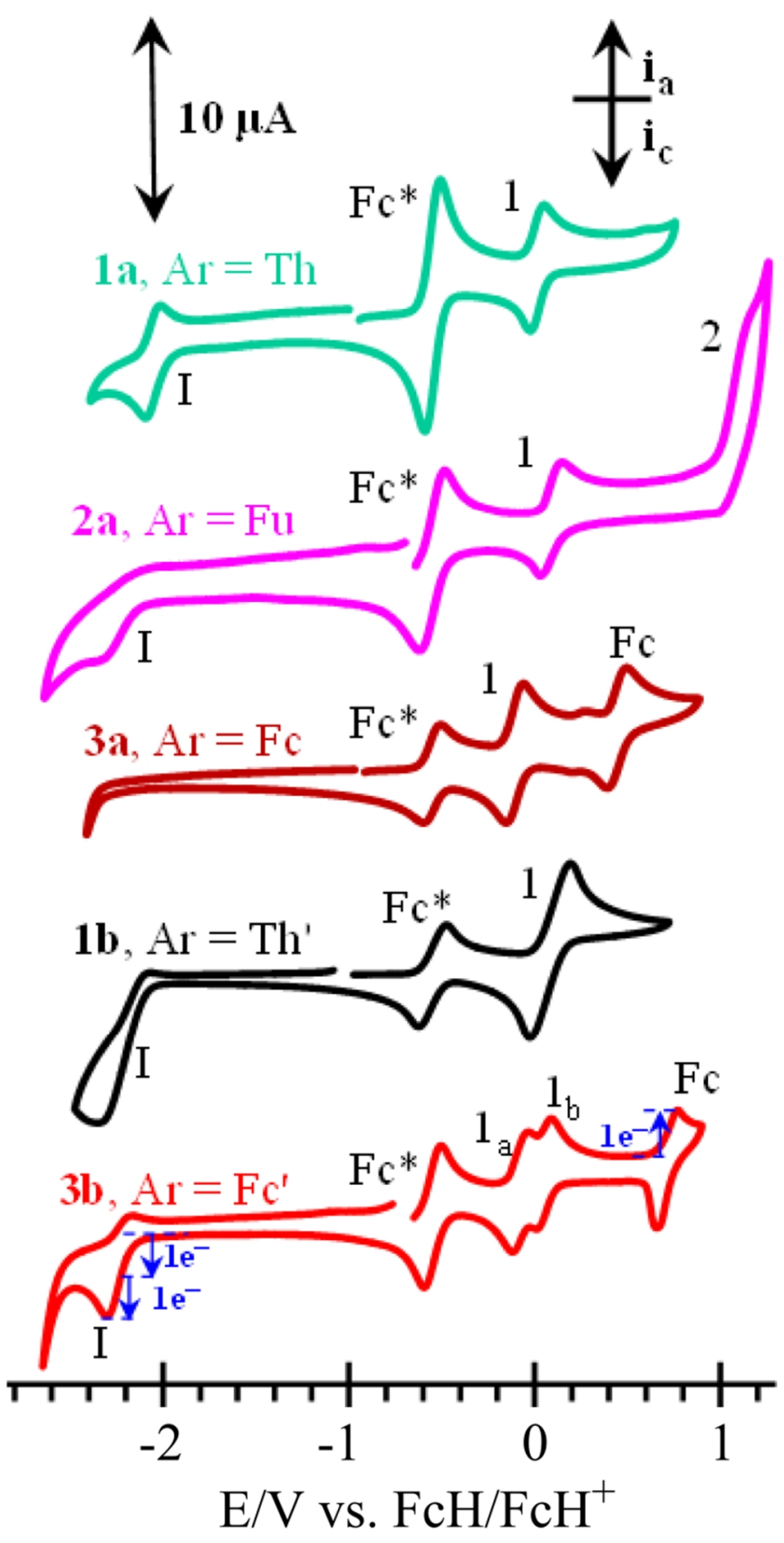

Figure 2. Cyclic voltammograms of $0.5 \mathrm{mmol} \cdot \mathrm{dm}^{-3}$ solutions of monocarbenes 1 a (green, top), $2 \mathrm{a}$ (mauve, $2^{\text {nd }}$ from top) and 3a (brown, third from the top) and biscarbene complexes $\left[\mathrm{Cp}(\mathrm{CO})_{2} \mathrm{Mn}=\mathrm{C}(\mathrm{OEt})-\mathrm{Ar} \mathrm{r}^{\prime}-(\mathrm{OEt}) \mathrm{C}=\mathrm{Mn}(\mathrm{CO}){ }_{2} \mathrm{Cp}\right] \mathbf{1 b}$ (black $2^{\text {nd }}$ from bottom) and $\mathbf{3 b}$ (red, bottom) in $\mathrm{CH}_{2} \mathrm{Cl}_{2}$ containing $0.1 \mathrm{~mol} \cdot \mathrm{dm}^{-3}\left[\mathrm{~N}\left({ }^{n} \mathrm{Bu}\right)_{4}\right]\left[\mathrm{PF}_{6}\right]$ as supporting electrolyte at a scan rate of $100 \mathrm{mV} \mathrm{s}^{-1}$ and $20^{\circ} \mathrm{C}$. $\mathrm{Fc}^{*}=$ decamethylferrocene $=$ internal standard. Under these conditions, each $\mathrm{Mn}$ centre is involved in a one-electron transfer redox process. 


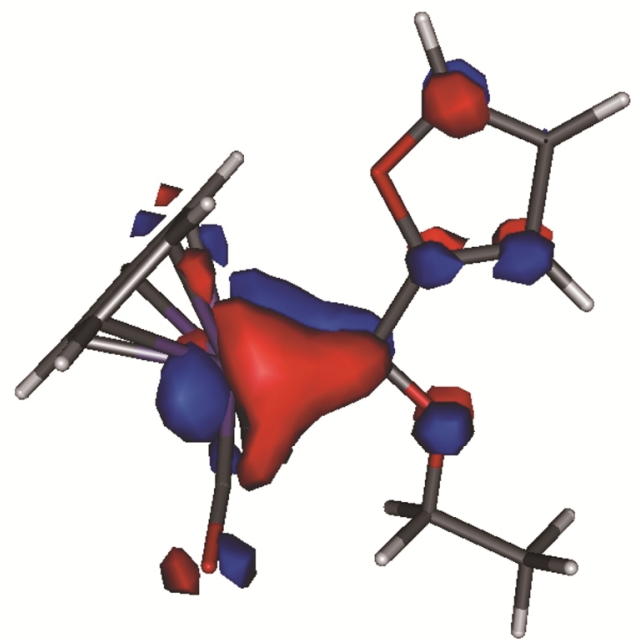

HOMO

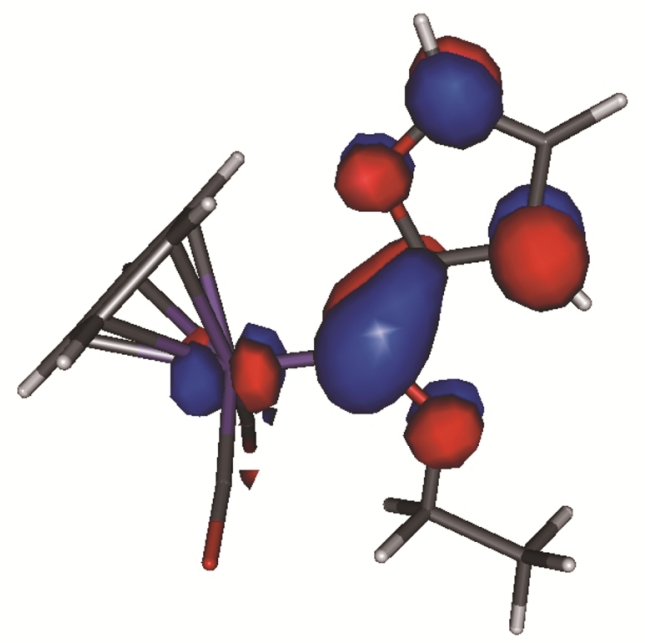

LUMO

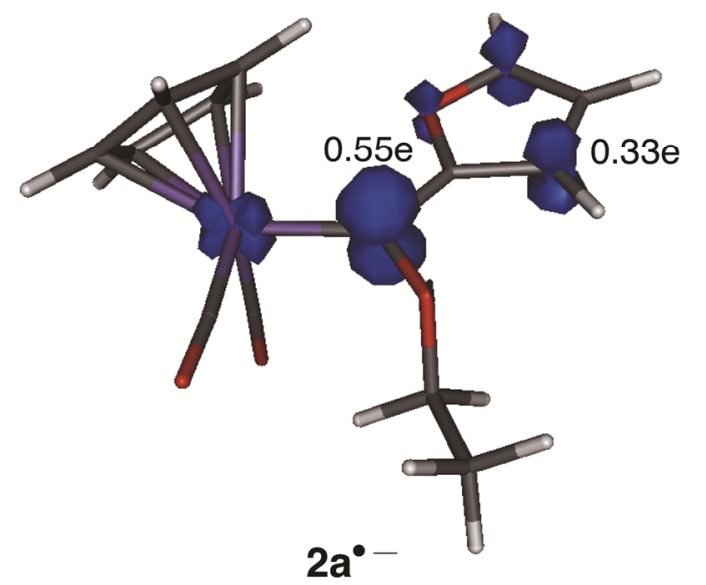

Figure 3. Computed frontier molecular orbitals of $\mathbf{2 a}$ (top) and spin density of radical anion $\mathbf{2} \mathrm{a}^{\mathbf{0}}$. 


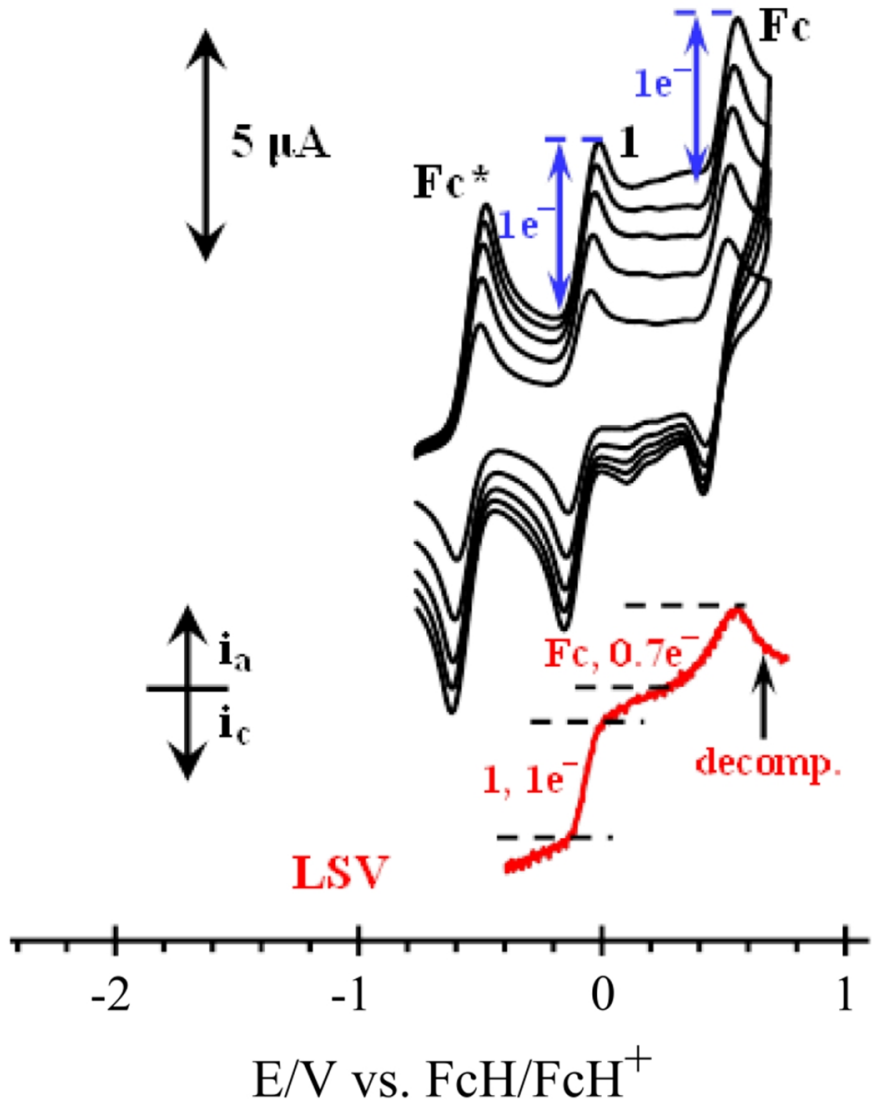

Figure 4. $\mathrm{CV}$ scans of $0.5 \mathrm{mmol} \cdot \mathrm{dm}^{-3}$ solutions of the $\left[(\mathrm{Cp})(\mathrm{OC})_{2} \mathrm{Mn}=\mathrm{C}(\mathrm{Fc})(\mathrm{OEt})\right]$, 3a, in $\mathrm{CH}_{2} \mathrm{Cl}_{2}$ containing 0.1 $\mathrm{mol} \cdot \mathrm{dm}^{-3}\left[\mathrm{~N}\left({ }^{n} \mathrm{Bu}\right)_{4}\right]\left[\mathrm{PF}_{6}\right]$ as supporting electrolyte at a scan rate of 100 (smallest currents), 200, 300, 400 and 500 $\mathrm{mV} \cdot \mathrm{s}^{-1}$ and $20^{\circ} \mathrm{C}$. The blue arrows on the CV's show the Mn centre is involved in the same number of electrons being transferred as the ferrocenyl group, that is, it involves a one-electron transfer process. The LSV shows that the doubly oxidised $3 a$ is unstable on LSV time scale $\left(1 \mathrm{mV} \cdot \mathrm{s}^{-1}\right.$; currents were enlarged three fold for clarity): the compound begins to decompose notably after 0.7 electrons have flown during $\mathrm{Fc}$ oxidation. $\mathrm{Fc}^{*}=$ decamethylferrocene. 


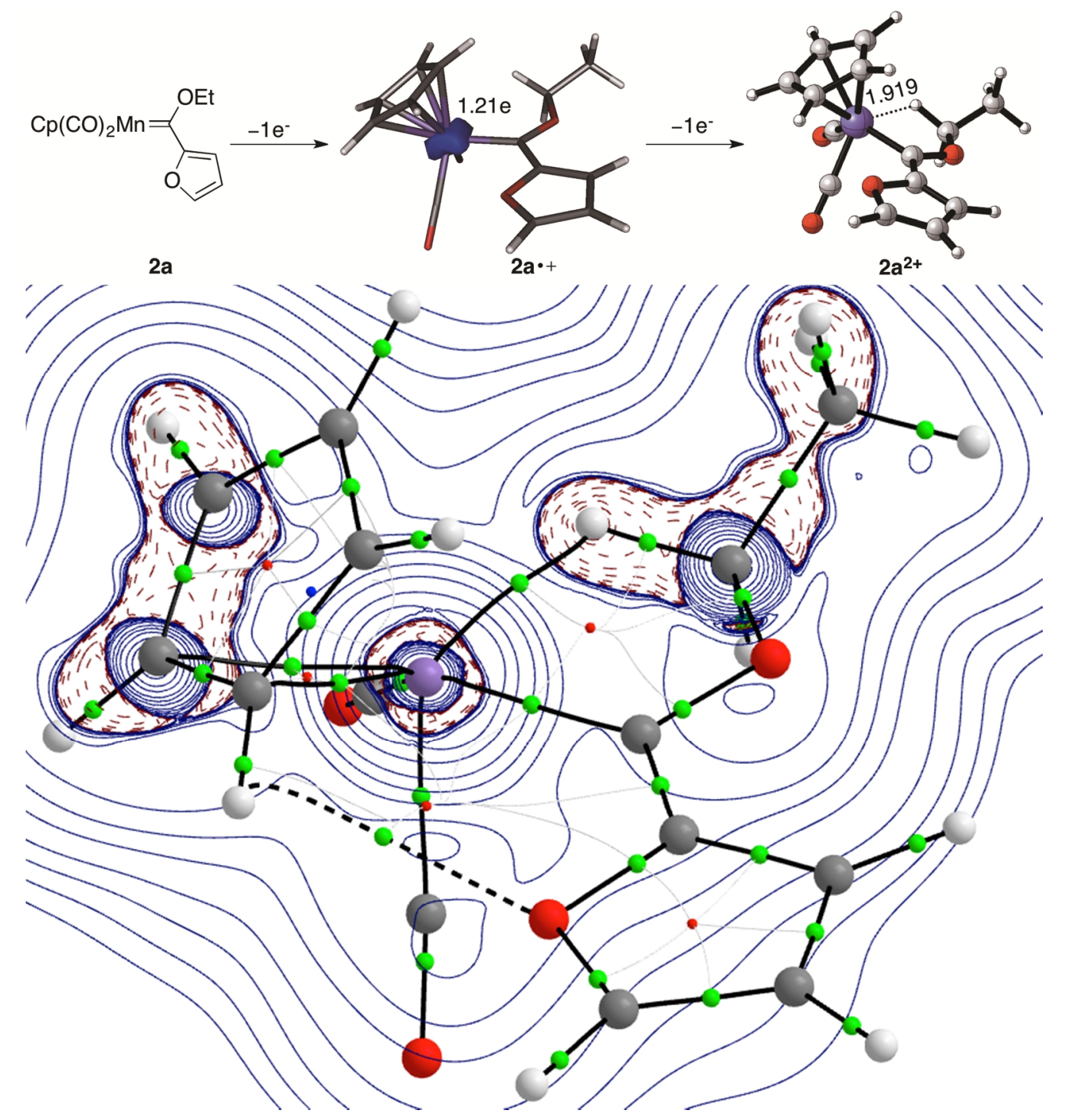

Figure 5. (a) Oxidation process of complex 2a. (b) Contour line diagrams $\nabla^{2} \rho(r)$ for complex $2 a^{2+}$ in the $\mathrm{Mn}-\mathrm{H}-\mathrm{C}$ plane. The solid lines connecting the atomic nuclei are the bond paths while the small red spheres indicate the corresponding bond critical points. 

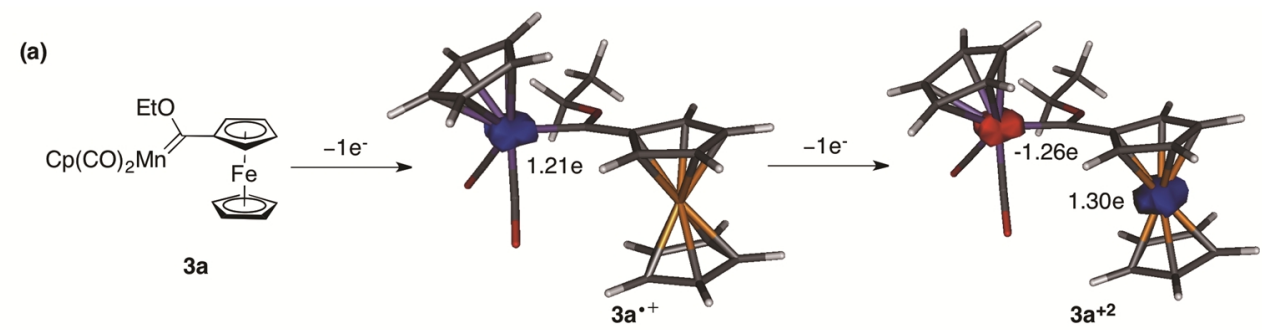

(b)
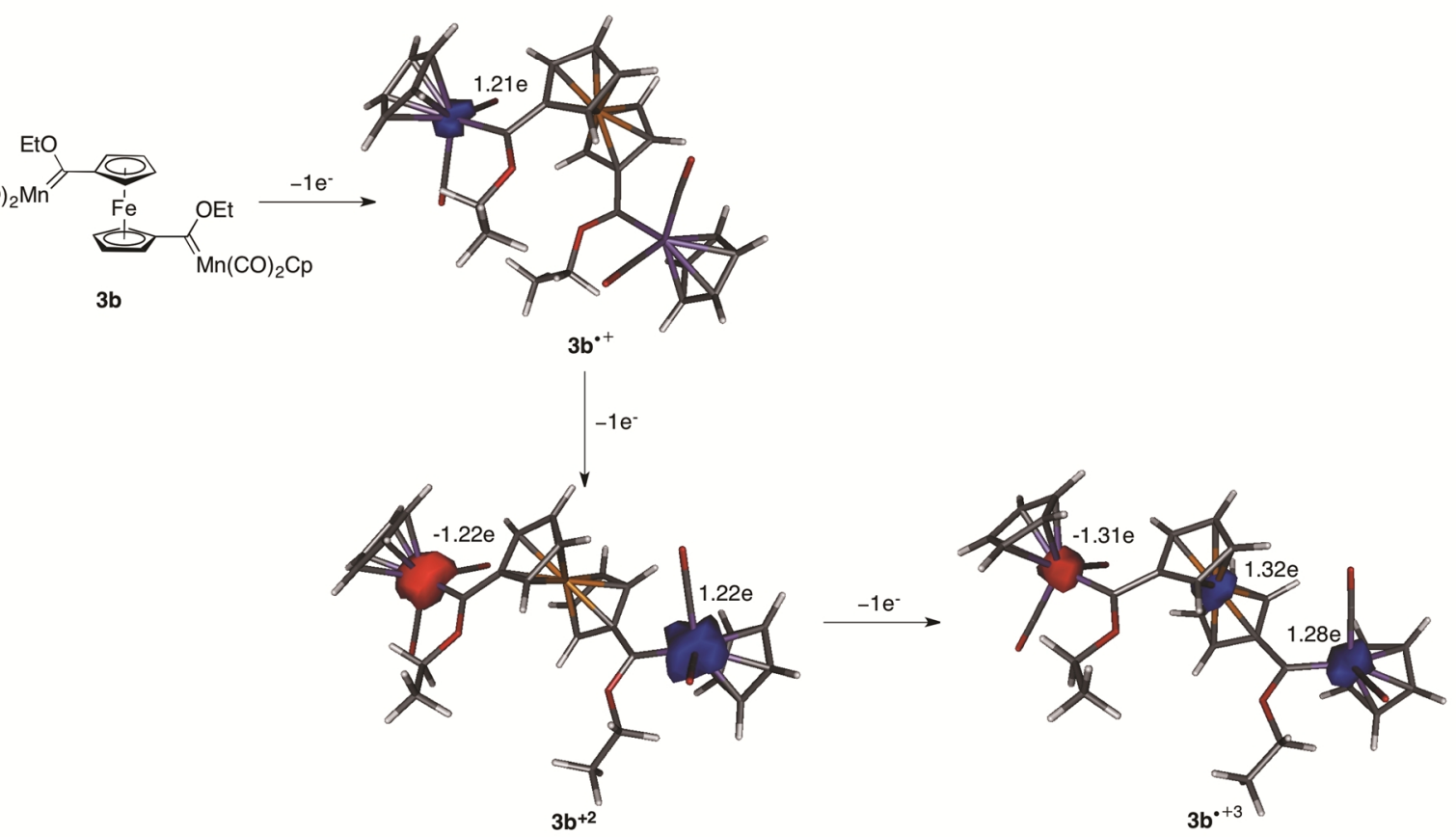

Figure 6. Oxidation processes of complexes $\mathbf{3 a}(\mathrm{a})$ and $\mathbf{3 b}$ (b). Spin densities were computed at the B3LYP/def2SVP level. 


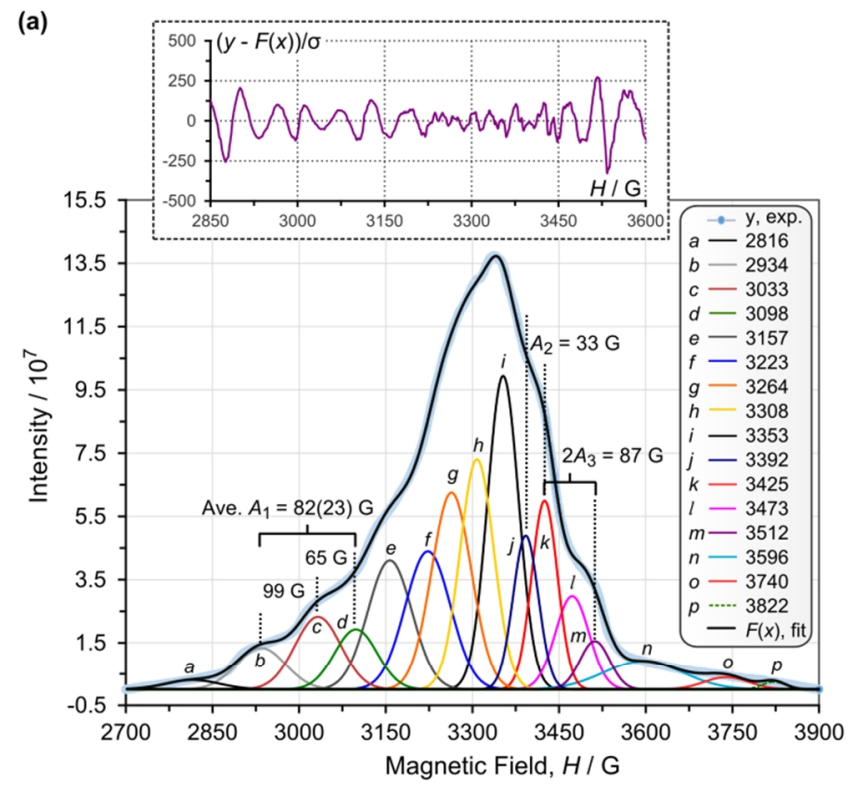

(b)

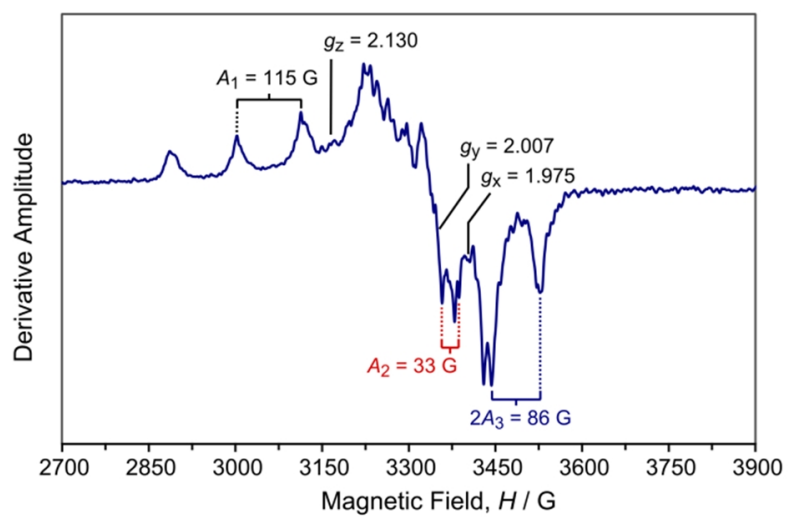

Figure 7. (a) ESR absorption spectrum of [3a] $\left[\mathrm{PF}_{6}\right]$ recorded in $\mathrm{CH}_{2} \mathrm{Cl}_{2}$ at $77 \mathrm{~K}$ shortly after oxidation of 3a with $\mathrm{AgPF}_{6}$. The spectral envelope is deconvoluted into a series of Voigt functions; the sum of these, $F(x)$, fits the experimental spectrum with a correlation coefficient of 0.9999. The raw spectral data are shown without background subtraction; the first $(2816 \mathrm{G})$ and last three $(\geq 3596 \mathrm{G})$ bands simply match the background and may be ignored. The upper inset shows the weighted fit residuals for the spectral region containing useful spectroscopic information; the right inset lists the $H_{\max }$ values for the Voigt components. (b) Derivative mode ESR

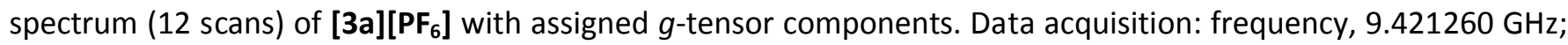
attenuation, $20.0 \mathrm{~dB}$; power, $2.00 \mathrm{~mW}$; modulation amplitude, $2.00 \mathrm{G}$ (modulation frequency $100.00 \mathrm{kHz}$ ); time constant, $81.92 \mathrm{~ms}$; conversion time, $38.00 \mathrm{~ms}$; sweep width, $1200 \mathrm{G}$ (centre field = $3300 \mathrm{G}$ ); data resolution, 2400 points. 


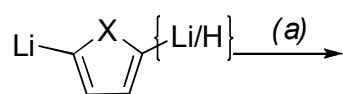

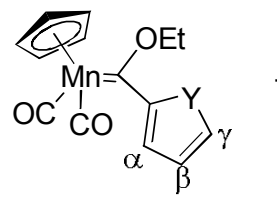

1a $Y=S, 45 \%$

2a $Y=0,56 \%$

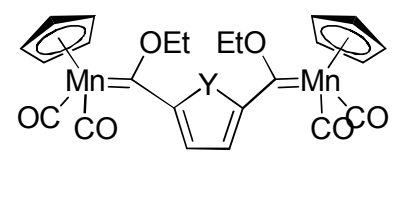

1b $Y=S, 80 \%$

2b $Y=0,32 \%$

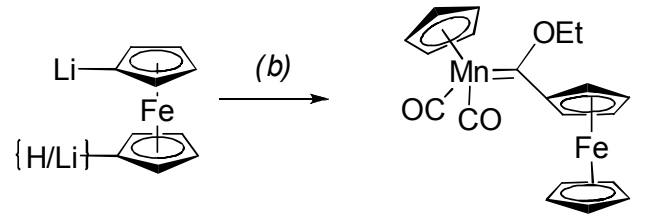

3a $38 \%$

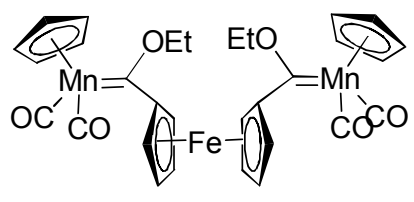

3b $46 \%$

Scheme 1. Reagents and conditions: (a) (i) 2 eq $\mathrm{CpMn}(\mathrm{CO}){ }_{3}$, thf, $-60{ }^{\circ} \mathrm{C}$; (ii) excess $\mathrm{Et}_{3} \mathrm{OBF}_{4}, \mathrm{CH}_{2} \mathrm{Cl}_{2},-40{ }^{\circ} \mathrm{C}$. (b) (i) 2 eq $\mathrm{CpMn}(\mathrm{CO})_{3}$, thf, $-50^{\circ} \mathrm{C}$; (iii) excess $\mathrm{Et}_{3} \mathrm{OBF}_{4}, \mathrm{CH}_{2} \mathrm{Cl}_{2},-40^{\circ} \mathrm{C}$.

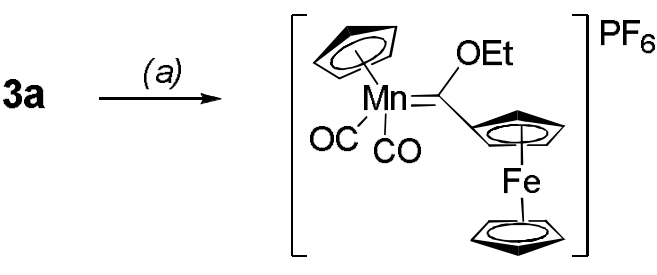

$[3 a] \mathrm{PF}_{6}$

Scheme 2: Reagents and conditions: (a) 1 eq $\mathrm{AgPF}_{6}, \mathrm{CH}_{2} \mathrm{Cl}_{2},-35^{\circ} \mathrm{C}$.

$\left[\mathrm{Cp}(\mathrm{CO})_{2} \stackrel{\ominus}{\mathrm{Mn}} \mathrm{n}^{\prime}-\dot{\mathrm{C}}(\mathrm{OEt})-\mathrm{Fc} c^{\prime}-(\mathrm{OEt}) \dot{\mathrm{C}}-\stackrel{\mathrm{Mn}}{ }^{\prime}(\mathrm{CO})_{2} \mathrm{Cp}\right]$ $+2 \mathrm{e}^{-} \uparrow \uparrow$

$\left[\mathrm{Cp}(\mathrm{CO})_{2} \mathrm{Mn}{ }^{\prime}=\mathrm{C}(\mathrm{OEt})-\mathrm{FC}^{\prime}-(\mathrm{OEt}) \mathrm{C}=\mathrm{Mn}^{\prime}(\mathrm{CO})_{2} \mathrm{Cp}\right]$ $+1 \mathrm{e}^{-} \| \begin{aligned} & -1 \mathrm{e}^{-} \\ & \text {wave }\end{aligned}$

$\left[\mathrm{Cp}(\mathrm{CO})_{2} \stackrel{\oplus \cdot \cdot}{\mathrm{M} n} n^{\prime \prime}=\mathrm{C}(\mathrm{OEt})-\mathrm{Fc}^{\prime}-(\mathrm{OEt}) \mathrm{C}=\mathrm{Mn}^{\prime}(\mathrm{CO})_{2} \mathrm{Cp}\right]$

$$
+1 \mathrm{e}^{-} \| \begin{aligned}
& -1 \mathrm{e}^{-} \\
& \text {wave } 1 \mathrm{~b}
\end{aligned}
$$

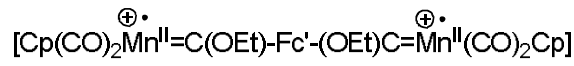

$$
+1 \mathrm{e}^{-} \| \begin{aligned}
& -1 \mathrm{e}^{-} \\
& \text {wave } \mathrm{Fc}
\end{aligned}
$$

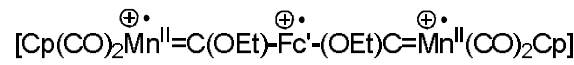

Scheme 3. Electrochemical reactions associated with $\mathbf{3 b .}$ 


\section{Supporting Information}

\section{Figure S1}

Figure S2

Table S1

Table S2

Table S3

Table 54

Table S5

Table 56

Table S7

Table S8

Table 59

Table S10

References 


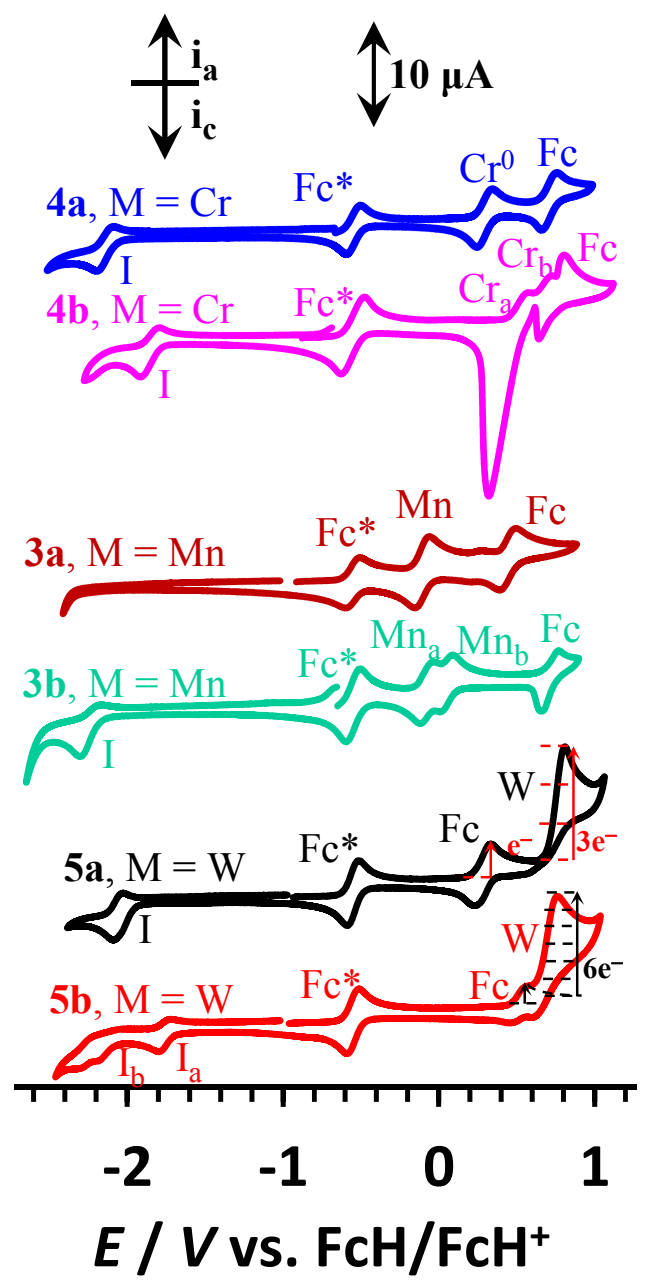

Figure S1. CV's of $0.5 \mathrm{mmol} \cdot \mathrm{dm}^{-3}$ solutions of monocarbene ferrocenyl complexes 3a $\left[\mathrm{Cp}(\mathrm{CO})_{2} \mathrm{Mn}=\mathrm{C}(\mathrm{OEt}) \mathrm{Fc}\right], \mathbf{2 a}\left[(\mathrm{CO})_{5} \mathrm{Cr}=\mathrm{C}(\mathrm{OEt}) \mathrm{Fc}\right]^{[1]}$, and $\mathbf{5 a}\left[(\mathrm{CO})_{5} \mathrm{~W}=\mathrm{C}(\mathrm{OEt}) \mathrm{Fc}\right]^{[2]}$, and biscarbene complexes $\mathbf{3 b} \quad\left[\mathrm{Cp}(\mathrm{CO})_{2} \mathrm{Mn}=\mathrm{C}(\mathrm{OEt})-\mathrm{Fc}^{\prime}-(\mathrm{OEt}) \mathrm{C}=\mathrm{Mn}(\mathrm{CO})_{2} \mathrm{Cp}\right], \quad \mathbf{4 b}$ $\left[(\mathrm{CO})_{5} \mathrm{Cr}=\mathrm{C}(\mathrm{OEt})-\mathrm{Fc}^{\prime}-(\mathrm{OEt}) \mathrm{C}=\mathrm{Cr}(\mathrm{CO})_{5}\right]^{[1]}$ and $\mathbf{5 b}\left[(\mathrm{CO})_{5} \mathrm{~W}=\mathrm{C}(\mathrm{OEt})-\mathrm{Fc}^{\prime}-(\mathrm{OEt}) \mathrm{C}=\mathrm{W}(\mathrm{CO})_{5}\right]^{[2]}$ in $\mathrm{CH}_{2} \mathrm{Cl}_{2}$ containing $0.1 \mathrm{~mol} \cdot \mathrm{dm}^{-3}\left[\mathrm{~N}\left({ }^{n} \mathrm{Bu}\right)_{4}\right]\left[\mathrm{PF}_{6}\right]$ as supporting electrolyte at a scan rate of $100 \mathrm{mV} \mathrm{s}^{-1}$ and $20{ }^{\circ} \mathrm{C} . \mathrm{Fc}^{*}=$ decamethylferrocene $=$ internal standard. 


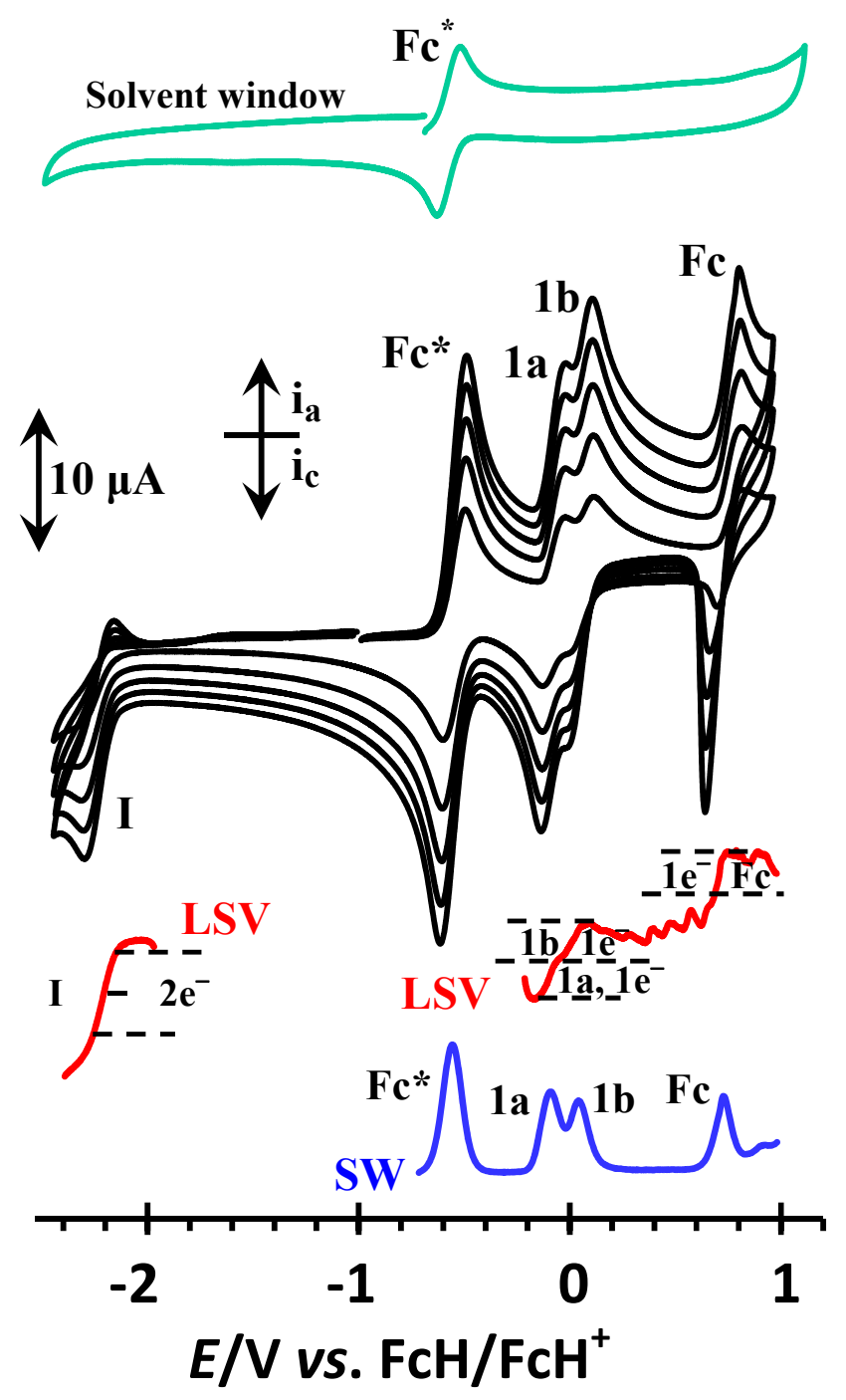

Figure S2. CV's (black traces) of $0.5 \mathrm{mmol} \cdot \mathrm{dm}^{-3}$ solutions of biscarbene complexes $\mathbf{3 b}$ $\left[\mathrm{Cp}(\mathrm{CO})_{2} \mathrm{Mn}=\mathrm{C}(\mathrm{OEt})-\mathrm{Fc}^{\prime}-(\mathrm{OEt}) \mathrm{C}=\mathrm{Mn}(\mathrm{CO})_{2} \mathrm{Cp}\right]$, at scan rates of 100 (smallest currents), 200, 300,400 and $500 \mathrm{mV} \mathrm{s}^{-1}$ in $\mathrm{CH}_{2} \mathrm{Cl}_{2}$ containing $0.2 \mathrm{~mol} \cdot \mathrm{dm}^{-3}\left[\mathrm{~N}\left({ }^{n} \mathrm{Bu}\right)_{4}\right]\left[\mathrm{PF}_{6}\right]$ as supporting electrolyte. LSV's (red traces) at $2 \mathrm{mV} \mathrm{s}^{-1}$ and an $\mathrm{SW}$ at $60 \mathrm{~Hz}$ is also shown. Fc* $=$ decamethylferrocene $=$ internal standard, temperature $20{ }^{\circ} \mathrm{C}$. 
Table S1. Cartesian coordinates (in $\AA$ ) and total energies (in a. u., zero-point vibrational energy included) of all the stationary points discussed in the text. All calculations have been performed at the B3LYP/def2-SVP level.

\begin{tabular}{|c|c|c|c|}
\hline C & 1.538414000 & 0.921776000 & 1.321873000 \\
\hline $\mathrm{C}$ & 1.562945000 & 0.938911000 & -1.296965000 \\
\hline $\mathrm{C}$ & -0.778128000 & 0.404065000 & -0.004732000 \\
\hline C & 2.033960000 & -1.771263000 & 1.139198000 \\
\hline $\mathrm{H}$ & 2.353596000 & -1.661010000 & 2.174781000 \\
\hline C & 2.822965000 & -1.477328000 & -0.010008000 \\
\hline $\mathrm{H}$ & 3.844098000 & -1.100289000 & -0.012450000 \\
\hline C & 2.025461000 & -1.763684000 & -1.155885000 \\
\hline $\mathrm{H}$ & 2.337658000 & -1.646839000 & -2.193001000 \\
\hline $\mathrm{C}$ & 0.759970000 & -2.240485000 & -0.718094000 \\
\hline $\mathrm{H}$ & -0.059839000 & -2.552144000 & -1.358513000 \\
\hline C & 0.764978000 & -2.245347000 & 0.707705000 \\
\hline $\mathrm{H}$ & -0.050118000 & -2.561421000 & 1.351946000 \\
\hline $\mathrm{C}$ & -2.007262000 & -0.408103000 & -0.004049000 \\
\hline O & -1.963025000 & -1.774506000 & 0.005126000 \\
\hline C & -3.227974000 & -2.238690000 & 0.003283000 \\
\hline $\mathrm{H}$ & -3.341853000 & -3.320215000 & 0.010110000 \\
\hline C & -4.122716000 & -1.201495000 & -0.007112000 \\
\hline $\mathrm{H}$ & -5.207848000 & -1.280653000 & -0.010899000 \\
\hline C & -3.335948000 & -0.016794000 & -0.011715000 \\
\hline $\mathrm{H}$ & -3.683730000 & 1.011597000 & -0.019785000 \\
\hline 0 & 1.925131000 & 1.549124000 & 2.214535000 \\
\hline O & 1.975710000 & 1.578176000 & -2.169354000 \\
\hline O & -1.257742000 & 1.660124000 & -0.007118000 \\
\hline $\mathrm{Mn}$ & 1.050725000 & -0.178436000 & 0.000512000 \\
\hline C & -0.474959000 & 2.853777000 & -0.012155000 \\
\hline $\mathrm{H}$ & 0.180485000 & 2.870792000 & 0.870668000 \\
\hline $\mathrm{H}$ & 0.159412000 & 2.875338000 & -0.910235000 \\
\hline C & -1.432410000 & 4.030685000 & 0.002230000 \\
\hline $\mathrm{H}$ & -2.065621000 & 4.013898000 & 0.902729000 \\
\hline $\mathrm{H}$ & -2.086811000 & 4.018671000 & -0.883079000 \\
\hline $\mathrm{H}$ & -0.863927000 & 4.973676000 & -0.002029000 \\
\hline
\end{tabular}

$3 a: E=-3412.653072$

$\begin{array}{llll}\mathrm{C} & 2.654815000 & -0.660137000 & -1.850294000 \\ \mathrm{C} & 3.739808000 & -0.066485000 & -1.144384000 \\ \mathrm{C} & 4.150889000 & -0.988469000 & -0.128880000 \\ \mathrm{C} & 3.317115000 & -2.131928000 & -0.211391000 \\ \mathrm{C} & 2.390075000 & -1.936314000 & -1.285636000 \\ \mathrm{Mn} & 2.085254000 & -0.397063000 & 0.263104000 \\ \mathrm{C} & 1.128189000 & -1.328292000 & 1.444270000 \\ \mathrm{O} & 0.545490000 & -1.966623000 & 2.217898000\end{array}$




$\begin{array}{lrrr}\mathrm{C} & 0.545637000 & 0.576225000 & -0.367799000 \\ \mathrm{O} & 0.368205000 & 1.888600000 & -0.488951000 \\ \mathrm{C} & 1.338918000 & 2.872900000 & -0.104837000 \\ \mathrm{C} & 0.912629000 & 4.199908000 & -0.701325000 \\ \mathrm{C} & -0.625515000 & -0.066273000 & -0.996416000 \\ \mathrm{C} & -1.607662000 & 0.610181000 & -1.819850000 \\ \mathrm{C} & -2.570235000 & -0.343031000 & -2.245341000 \\ \mathrm{C} & -2.221609000 & -1.610259000 & -1.682277000 \\ \mathrm{C} & -1.036106000 & -1.447407000 & -0.915243000 \\ \mathrm{Fe} & -2.520989000 & -0.214327000 & -0.164854000 \\ \mathrm{C} & -3.828468000 & 1.161345000 & 0.680803000 \\ \mathrm{C} & -2.680362000 & 0.998737000 & 1.511962000 \\ \mathrm{C} & -2.605088000 & -0.374240000 & 1.904872000 \\ \mathrm{C} & -3.710039000 & -1.058295000 & 1.315043000 \\ \mathrm{C} & -4.465134000 & -0.112566000 & 0.555711000 \\ \mathrm{C} & 2.623022000 & 0.740064000 & 1.522234000 \\ \mathrm{O} & 3.067754000 & 1.407190000 & 2.361256000 \\ \mathrm{H} & -1.588220000 & 1.667328000 & -2.071583000 \\ \mathrm{H} & -0.544498000 & -2.225658000 & -0.339458000 \\ \mathrm{H} & -2.780922000 & -2.537536000 & -1.799007000 \\ \mathrm{H} & -3.437686000 & -0.139442000 & -2.872023000 \\ \mathrm{H} & 2.329883000 & 2.559956000 & -0.463716000 \\ \mathrm{H} & 1.378332000 & 2.923093000 & 0.992991000 \\ \mathrm{H} & -1.826285000 & -0.827125000 & 2.515960000 \\ \mathrm{H} & -3.924763000 & -2.122125000 & 1.407047000 \\ \mathrm{H} & -5.360635000 & -0.326722000 & -0.026112000 \\ \mathrm{H} & -4.150807000 & 2.087784000 & 0.207576000 \\ \mathrm{H} & -1.966251000 & 1.777702000 & 1.775141000 \\ \mathrm{H} & 1.629409000 & 4.984679000 & -0.413589000 \\ \mathrm{H} & 0.879451000 & 4.148633000 & -1.800708000 \\ \mathrm{H} & -0.084167000 & 4.495592000 & -0.339223000 \\ \mathrm{H} & 4.963239000 & -0.837566000 & 0.580404000 \\ \mathrm{H} & 3.382800000 & -3.015196000 & 0.422342000 \\ \mathrm{H} & 4.200986000 & 0.895207000 & -1.362535000 \\ \mathrm{H} & 1.636526000 & -2.643186000 & -1.625491000 \\ \mathrm{H} & 2.121117000 & -0.213660000 & -2.688351000\end{array}$

$3 b: E=-5175.074320$

$\begin{array}{lrrr}\text { Mn } & -3.718216000 & -0.456792000 & -0.264747000 \\ \mathrm{C} & -2.061658000 & -0.207440000 & 0.708130000 \\ \mathrm{O} & -1.315675000 & -1.131156000 & 1.300901000 \\ \mathrm{C} & -3.286498000 & 0.681013000 & -1.561722000 \\ \mathrm{O} & -3.086271000 & 1.419659000 & -2.434413000 \\ \mathrm{C} & -3.154808000 & -1.841688000 & -1.229481000 \\ \mathrm{O} & -2.851159000 & -2.743981000 & -1.895534000 \\ \mathrm{C} & -4.779136000 & -0.333816000 & 1.665264000 \\ \mathrm{H} & -4.287374000 & -0.275519000 & 2.635623000 \\ \mathrm{C} & -5.172099000 & -1.528157000 & 1.002066000 \\ \mathrm{H} & -5.063161000 & -2.542468000 & 1.382102000 \\ \mathrm{C} & -5.789123000 & -1.155999000 & -0.235491000 \\ \mathrm{H} & -6.206306000 & -1.839295000 & -0.973466000 \\ \mathrm{C} & -5.776549000 & 0.259013000 & -0.321847000\end{array}$




\begin{tabular}{|c|c|c|c|}
\hline $\mathrm{H}$ & -6.183664000 & 0.850811000 & -1.140582000 \\
\hline $\mathrm{C}$ & -5.151932000 & 0.777221000 & 0.857325000 \\
\hline $\mathrm{H}$ & -5.016364000 & 1.826945000 & 1.109067000 \\
\hline Mn & 3.718261000 & -0.456281000 & 0.264836000 \\
\hline C & 2.061715000 & -0.207259000 & -0.708117000 \\
\hline 0 & 1.316099000 & -1.131189000 & -1.301035000 \\
\hline C & 3.154798000 & -1.840793000 & 1.230103000 \\
\hline O & 2.851110000 & -2.742807000 & 1.896519000 \\
\hline C & 3.286468000 & 0.681926000 & 1.561399000 \\
\hline O & 3.086150000 & 1.420836000 & 2.433848000 \\
\hline C & 4.779327000 & -0.337467000 & -1.665446000 \\
\hline $\mathrm{H}$ & 4.287585000 & -0.282192000 & -2.635993000 \\
\hline C & 5.173373000 & -1.529627000 & -0.999105000 \\
\hline $\mathrm{H}$ & 5.065285000 & -2.545051000 & -1.376418000 \\
\hline $\mathrm{C}$ & 5.789959000 & -1.153697000 & 0.237541000 \\
\hline $\mathrm{H}$ & 6.207675000 & -1.834648000 & 0.977372000 \\
\hline C & 5.776011000 & 0.261535000 & 0.320147000 \\
\hline $\mathrm{H}$ & 6.182378000 & 0.855854000 & 1.137432000 \\
\hline C & 5.150972000 & 0.776090000 & -0.860318000 \\
\hline $\mathrm{H}$ & 5.014362000 & 1.825025000 & -1.114773000 \\
\hline $\mathrm{Fe}$ & -0.000213000 & 2.113774000 & -0.000113000 \\
\hline C & -1.466582000 & 1.094568000 & 1.064746000 \\
\hline C & -1.924944000 & 2.412590000 & 0.694754000 \\
\hline $\mathrm{H}$ & -2.780787000 & 2.637317000 & 0.065608000 \\
\hline C & -1.054496000 & 3.370600000 & 1.281297000 \\
\hline $\mathrm{H}$ & -1.132658000 & 4.451084000 & 1.168042000 \\
\hline C & -0.041065000 & 2.672637000 & 2.011403000 \\
\hline $\mathrm{H}$ & 0.797434000 & 3.117300000 & 2.544537000 \\
\hline C & -0.284271000 & 1.283089000 & 1.879390000 \\
\hline $\mathrm{H}$ & 0.316618000 & 0.484224000 & 2.303612000 \\
\hline C & 1.466280000 & 1.094553000 & -1.064762000 \\
\hline C & 0.283936000 & 1.282737000 & -1.879435000 \\
\hline $\mathrm{H}$ & -0.316829000 & 0.483692000 & -2.303494000 \\
\hline C & 0.040506000 & 2.672218000 & -2.011731000 \\
\hline $\mathrm{H}$ & -0.798070000 & 3.116618000 & -2.544963000 \\
\hline C & 1.053854000 & 3.370481000 & -1.281796000 \\
\hline $\mathrm{H}$ & 1.131855000 & 4.450996000 & -1.168704000 \\
\hline C & 1.924455000 & 2.412728000 & -0.695055000 \\
\hline $\mathrm{H}$ & 2.780288000 & 2.637811000 & -0.066015000 \\
\hline C & -1.600364000 & -2.539776000 & 1.284245000 \\
\hline $\mathrm{H}$ & -1.278622000 & -2.947029000 & 0.314053000 \\
\hline $\mathrm{H}$ & -2.685344000 & -2.684928000 & 1.365278000 \\
\hline C & -0.850765000 & -3.183401000 & 2.434334000 \\
\hline $\mathrm{H}$ & -1.046235000 & -4.267349000 & 2.440106000 \\
\hline $\mathrm{H}$ & -1.181936000 & -2.770134000 & 3.399694000 \\
\hline $\mathrm{H}$ & 0.235660000 & -3.031614000 & 2.347181000 \\
\hline C & 1.601156000 & -2.539729000 & -1.284167000 \\
\hline $\mathrm{H}$ & 1.279723000 & -2.946930000 & -0.313849000 \\
\hline $\mathrm{H}$ & 2.686157000 & -2.684601000 & -1.365387000 \\
\hline C & 0.851497000 & -3.183757000 & -2.433997000 \\
\hline $\mathrm{H}$ & 1.047014000 & -4.267695000 & -2.439433000 \\
\hline $\mathrm{H}$ & 1.182533000 & -2.770782000 & -3.399527000 \\
\hline $\mathrm{H}$ & -0.234927000 & -3.031997000 & -2.346758000 \\
\hline
\end{tabular}


$2 a^{*}: E=-1992.240027$

$\begin{array}{lrrr}\mathrm{C} & 1.710577000 & 1.452333000 & 0.448670000 \\ \mathrm{C} & 1.020875000 & 0.345472000 & -1.769439000 \\ \mathrm{C} & -0.778261000 & 0.335147000 & 0.218043000 \\ \mathrm{C} & 1.933234000 & -1.264885000 & 1.675098000 \\ \mathrm{H} & 1.977875000 & -0.854053000 & 2.682721000 \\ \mathrm{C} & 2.946383000 & -1.145707000 & 0.666525000 \\ \mathrm{H} & 3.906050000 & -0.642036000 & 0.778832000 \\ \mathrm{C} & 2.481098000 & -1.810138000 & -0.498496000 \\ \mathrm{H} & 3.023356000 & -1.902145000 & -1.439418000 \\ \mathrm{C} & 1.180687000 & -2.341870000 & -0.222974000 \\ \mathrm{H} & 0.539603000 & -2.886041000 & -0.911578000 \\ \mathrm{C} & 0.852981000 & -1.991855000 & 1.115334000 \\ \mathrm{H} & -0.088358000 & -2.217286000 & 1.610174000 \\ \mathrm{C} & -1.931183000 & -0.475939000 & 0.135817000 \\ \mathrm{O} & -1.838417000 & -1.804613000 & -0.264173000 \\ \mathrm{C} & -3.091031000 & -2.343545000 & -0.251157000 \\ \mathrm{H} & -3.168287000 & -3.386799000 & -0.548715000 \\ \mathrm{C} & -4.012051000 & -1.407308000 & 0.151009000 \\ \mathrm{H} & -5.085655000 & -1.569556000 & 0.252878000 \\ \mathrm{C} & -3.293357000 & -0.210616000 & 0.404609000 \\ \mathrm{H} & -3.677223000 & 0.742967000 & 0.755241000 \\ \mathrm{O} & 2.153922000 & 2.468941000 & 0.819926000 \\ \mathrm{O} & 0.958667000 & 0.634408000 & -2.899920000 \\ \mathrm{O} & -1.183840000 & 1.623624000 & 0.637535000 \\ \mathrm{Mn} & 1.154988000 & -0.135179000 & -0.077082000 \\ \mathrm{C} & -1.143366000 & 2.646444000 & -0.327799000 \\ \mathrm{H} & -0.177691000 & 2.640865000 & -0.865432000 \\ \mathrm{H} & -1.933747000 & 2.488254000 & -1.093360000 \\ \mathrm{C} & -1.337042000 & 3.982925000 & 0.371685000 \\ \mathrm{H} & -0.515274000 & 4.155534000 & 1.084340000 \\ \mathrm{H} & -2.286971000 & 3.998456000 & 0.931441000 \\ \mathrm{H} & -1.348277000 & 4.809679000 & -0.358559000\end{array}$

$2 a^{\cdot+}: E=-1991.991076$

$\begin{array}{lrrr}\text { C } & 0.341886000 & -1.622427000 & 1.353039000 \\ \mathrm{C} & 1.748514000 & 0.492970000 & 1.485810000 \\ \mathrm{C} & -0.754890000 & 0.675636000 & 0.054328000 \\ \mathrm{C} & 1.899168000 & -2.075599000 & -1.022369000 \\ \mathrm{H} & 1.942800000 & -3.104518000 & -0.665512000 \\ \mathrm{C} & 2.859920000 & -1.066110000 & -0.761234000 \\ \mathrm{H} & 3.778502000 & -1.189641000 & -0.188863000 \\ \mathrm{C} & 2.420371000 & 0.134809000 & -1.404227000 \\ \mathrm{H} & 2.965908000 & 1.077329000 & -1.430678000 \\ \mathrm{C} & 1.184062000 & -0.146100000 & -2.058339000 \\ \mathrm{H} & 0.606003000 & 0.547331000 & -2.667957000 \\ \mathrm{C} & 0.858535000 & -1.513087000 & -1.813563000 \\ \mathrm{H} & -0.026538000 & -2.037834000 & -2.169793000 \\ \mathrm{C} & -2.038387000 & 0.047046000 & -0.037574000\end{array}$




$\begin{array}{lrrr}\mathrm{O} & -2.103376000 & -1.324791000 & -0.070172000 \\ \mathrm{C} & -3.396835000 & -1.667251000 & -0.147230000 \\ \mathrm{H} & -3.614285000 & -2.733383000 & -0.177023000 \\ \mathrm{C} & -4.204408000 & -0.550950000 & -0.170446000 \\ \mathrm{H} & -5.290835000 & -0.540282000 & -0.227696000 \\ \mathrm{C} & -3.331198000 & 0.557371000 & -0.100446000 \\ \mathrm{H} & -3.593635000 & 1.612957000 & -0.091515000 \\ \mathrm{O} & 0.008288000 & -2.383666000 & 2.130520000 \\ \mathrm{O} & 2.271020000 & 1.018923000 & 2.353229000 \\ \mathrm{O} & -0.893760000 & 1.974587000 & 0.045110000 \\ \mathrm{Mn} & 0.932307000 & -0.391731000 & 0.075432000 \\ \mathrm{C} & 0.210446000 & 2.913185000 & 0.139090000 \\ \mathrm{H} & 0.501016000 & 2.968552000 & 1.199532000 \\ \mathrm{H} & 1.055066000 & 2.513538000 & -0.440643000 \\ \mathrm{C} & -0.260058000 & 4.253393000 & -0.379070000 \\ \mathrm{H} & -1.115286000 & 4.623934000 & 0.205022000 \\ \mathrm{H} & -0.553681000 & 4.192521000 & -1.437661000 \\ \mathrm{H} & 0.557152000 & 4.985056000 & -0.289122000\end{array}$

$2 a^{2+}: E=-1991.538744$

$\begin{array}{lrrr}\mathrm{O} & -1.070654000 & 1.666773000 & -0.433211000 \\ \mathrm{O} & 0.194664000 & -0.434235000 & -2.911922000 \\ \mathrm{C} & -0.935678000 & 0.400307000 & -0.149962000 \\ \mathrm{C} & -2.092925000 & -0.354397000 & 0.026567000 \\ \mathrm{C} & -2.311032000 & -1.711204000 & 0.346910000 \\ \mathrm{H} & -1.544790000 & -2.463103000 & 0.526576000 \\ \mathrm{C} & -3.693322000 & -1.899586000 & 0.388123000 \\ \mathrm{H} & -4.240066000 & -2.816317000 & 0.603277000 \\ \mathrm{C} & -4.250958000 & -0.655263000 & 0.092541000 \\ \mathrm{H} & -5.287823000 & -0.323855000 & 0.011476000 \\ \mathrm{C} & 0.118191000 & 2.456119000 & -0.685315000 \\ \mathrm{H} & 0.199631000 & 2.584524000 & -1.775387000 \\ \mathrm{H} & 1.048147000 & 1.878784000 & -0.348056000 \\ \mathrm{C} & 0.058017000 & 3.770935000 & 0.050591000 \\ \mathrm{H} & 0.945335000 & 4.374070000 & -0.194462000 \\ \mathrm{H} & 0.003259000 & 3.636909000 & 1.140593000 \\ \mathrm{H} & -0.831958000 & 4.327538000 & -0.283187000 \\ \mathrm{C} & 0.549261000 & -0.278937000 & -1.847411000 \\ \mathrm{C} & 0.531225000 & 0.511660000 & 1.689312000 \\ \mathrm{O} & 0.168726000 & 0.824420000 & 2.715972000 \\ \mathrm{O} & -3.318436000 & 0.259115000 & -0.121782000 \\ \mathrm{C} & 2.729976000 & -0.662479000 & 1.272747000 \\ \mathrm{C} & 1.816707000 & -1.781217000 & 1.070135000 \\ \mathrm{C} & 3.289140000 & -0.304113000 & 0.024108000 \\ \mathrm{H} & 3.006340000 & -0.232795000 & 2.237606000 \\ \mathrm{C} & 1.819888000 & -2.088854000 & -0.294058000 \\ \mathrm{H} & 1.274934000 & -2.309460000 & 1.855843000 \\ \mathrm{C} & 2.736239000 & -1.164932000 & -0.952356000 \\ \mathrm{H} & 4.011736000 & 0.493957000 & -0.154162000 \\ \mathrm{H} & 1.280588000 & -2.903331000 & -0.779622000 \\ \mathrm{H} & 3.018298000 & -1.190582000 & -2.006775000 \\ \mathrm{Mn} & 1.085344000 & -0.040527000 & -0.040710000\end{array}$


$3 a^{\cdot+}: E=-3412.436669$

\begin{tabular}{|c|c|c|c|}
\hline C & 3.067529000 & -0.010308000 & -1.704505000 \\
\hline C & 4.009396000 & -0.019868000 & -0.635659000 \\
\hline C & 4.039689000 & -1.341197000 & -0.085107000 \\
\hline $\mathrm{C}$ & 3.123250000 & -2.137648000 & -0.823027000 \\
\hline C & 2.517032000 & -1.320929000 & -1.815497000 \\
\hline $\mathrm{Mn}$ & 2.044224000 & -0.461368000 & 0.163702000 \\
\hline C & 1.049902000 & -1.682640000 & 1.131812000 \\
\hline 0 & 0.472977000 & -2.450517000 & 1.749443000 \\
\hline C & 0.500544000 & 0.710466000 & -0.361701000 \\
\hline O & 0.480720000 & 2.018567000 & -0.314844000 \\
\hline $\mathrm{C}$ & 1.506484000 & 2.843753000 & 0.288800000 \\
\hline $\mathrm{C}$ & 1.306542000 & 4.267183000 & -0.182492000 \\
\hline C & -0.660623000 & 0.205971000 & -1.052043000 \\
\hline C & -1.690318000 & 1.038554000 & -1.659978000 \\
\hline C & -2.653557000 & 0.185758000 & -2.247151000 \\
\hline C & -2.280363000 & -1.170572000 & -1.989342000 \\
\hline C & -1.073748000 & -1.174401000 & -1.247080000 \\
\hline $\mathrm{Fe}$ & -2.511042000 & -0.138413000 & -0.180557000 \\
\hline C & -3.723459000 & 1.061372000 & 1.018226000 \\
\hline C & -2.645004000 & 0.539661000 & 1.788555000 \\
\hline $\mathrm{C}$ & -2.717439000 & -0.888832000 & 1.751125000 \\
\hline C & -3.848153000 & -1.246226000 & 0.958695000 \\
\hline C & -4.466848000 & -0.044092000 & 0.500937000 \\
\hline C & 2.420255000 & 0.289885000 & 1.815605000 \\
\hline O & 2.673139000 & 0.721319000 & 2.841897000 \\
\hline $\mathrm{H}$ & -1.684255000 & 2.125194000 & -1.684247000 \\
\hline $\mathrm{H}$ & -0.551117000 & -2.066906000 & -0.913057000 \\
\hline $\mathrm{H}$ & -2.842231000 & -2.053887000 & -2.288985000 \\
\hline $\mathrm{H}$ & -3.547074000 & 0.507821000 & -2.780046000 \\
\hline $\mathrm{H}$ & 2.491368000 & 2.448392000 & -0.000516000 \\
\hline $\mathrm{H}$ & 1.399024000 & 2.763781000 & 1.381461000 \\
\hline $\mathrm{H}$ & -2.040523000 & -1.582694000 & 2.245909000 \\
\hline $\mathrm{H}$ & -4.172099000 & -2.259682000 & 0.725985000 \\
\hline $\mathrm{H}$ & -5.345767000 & 0.019008000 & -0.139082000 \\
\hline $\mathrm{H}$ & -3.935988000 & 2.114621000 & 0.841515000 \\
\hline $\mathrm{H}$ & -1.890628000 & 1.129754000 & 2.307573000 \\
\hline $\mathrm{H}$ & 2.063899000 & 4.916117000 & 0.282787000 \\
\hline $\mathrm{H}$ & 1.410352000 & 4.343899000 & -1.275138000 \\
\hline $\mathrm{H}$ & 0.312757000 & 4.641662000 & 0.104264000 \\
\hline $\mathrm{H}$ & 4.672271000 & -1.683747000 & 0.732678000 \\
\hline $\mathrm{H}$ & 2.914397000 & -3.193407000 & -0.651260000 \\
\hline $\mathrm{H}$ & 4.631786000 & 0.815750000 & -0.317404000 \\
\hline $\mathrm{H}$ & 1.763859000 & -1.638701000 & -2.535173000 \\
\hline $\mathrm{H}$ & 2.830099000 & 0.835647000 & -2.348315000 \\
\hline
\end{tabular}

$3 a^{2+}: E=-3412.091750$

$\begin{array}{ll}\text { C } & 2.819633000 \\ \text { C } & 3.859614000 \\ \text { C } & 4.261400000\end{array}$

$-0.433088000$

$-1.871304000$

0.087744000

$-1.046366000$

$-0.940927000$

$-0.142293000$ 


$\begin{array}{lrrr}\mathrm{C} & 3.471483000 & -2.088382000 & -0.394585000 \\ \mathrm{C} & 2.568592000 & -1.778459000 & -1.459799000 \\ \mathrm{Mn} & 2.102488000 & -0.430670000 & 0.164437000 \\ \mathrm{C} & 1.080943000 & -1.601711000 & 1.159012000 \\ \mathrm{O} & 0.431498000 & -2.314160000 & 1.772200000 \\ \mathrm{C} & 0.549699000 & 0.688950000 & -0.331351000 \\ \mathrm{O} & 0.466057000 & 1.979978000 & -0.251213000 \\ \mathrm{C} & 1.519210000 & 2.865465000 & 0.263971000 \\ \mathrm{C} & 1.294695000 & 4.251457000 & -0.291285000 \\ \mathrm{C} & -0.672008000 & 0.176909000 & -1.003583000 \\ \mathrm{C} & -1.642464000 & 1.013461000 & -1.683517000 \\ \mathrm{C} & -2.576204000 & 0.170642000 & -2.336377000 \\ \mathrm{C} & -2.228864000 & -1.182956000 & -2.059806000 \\ \mathrm{C} & -1.068978000 & -1.190772000 & -1.242827000 \\ \mathrm{Fe} & -2.592306000 & -0.140482000 & -0.186306000 \\ \mathrm{C} & -3.959002000 & 1.017923000 & 0.891387000 \\ \mathrm{C} & -2.871747000 & 0.674312000 & 1.753339000 \\ \mathrm{C} & -2.836932000 & -0.747193000 & 1.877759000 \\ \mathrm{C} & -3.892893000 & -1.285817000 & 1.094097000 \\ \mathrm{C} & -4.588810000 & -0.200324000 & 0.480165000 \\ \mathrm{C} & 2.597713000 & 0.345084000 & 1.814381000 \\ \mathrm{O} & 2.913633000 & 0.779977000 & 2.814954000 \\ \mathrm{H} & -1.630013000 & 2.101640000 & -1.710054000 \\ \mathrm{H} & -0.580403000 & -2.088278000 & -0.870441000 \\ \mathrm{H} & -2.778141000 & -2.064064000 & -2.393438000 \\ \mathrm{H} & -3.433456000 & 0.501987000 & -2.923871000 \\ \mathrm{H} & 2.486759000 & 2.439838000 & -0.036634000 \\ \mathrm{H} & 1.434724000 & 2.842177000 & 1.360982000 \\ \mathrm{H} & -2.110745000 & -1.326459000 & 2.448620000 \\ \mathrm{H} & -4.116937000 & -2.345298000 & 0.964543000 \\ \mathrm{H} & -5.452117000 & -0.286206000 & -0.180576000 \\ \mathrm{H} & -4.265224000 & 2.025702000 & 0.610522000 \\ \mathrm{H} & -2.191020000 & 1.376233000 & 2.234741000 \\ \mathrm{H} & 2.066425000 & 4.924793000 & 0.112346000 \\ \mathrm{H} & 1.371854000 & 4.265053000 & -1.388482000 \\ \mathrm{H} & 0.313520000 & 4.648774000 & 0.007524000 \\ \mathrm{H} & 5.044817000 & -0.858743000 & 0.611886000 \\ \mathrm{H} & 3.549659000 & -3.043459000 & 0.125067000 \\ \mathrm{H} & 4.312604000 & 1.076008000 & -1.124779000 \\ \mathrm{H} & 1.871221000 & -2.474628000 & -1.924294000 \\ \mathrm{H} & 2.344253000 & 0.083945000 & -2.704275000\end{array}$

$3 b^{\cdot+}: E=-5174.857950$

$\begin{array}{lrrr}\text { Mn } & -3.696867000 & -0.436984000 & -0.307512000 \\ \mathrm{C} & -2.119745000 & -0.203186000 & 0.760709000 \\ \mathrm{O} & -1.437947000 & -1.127895000 & 1.434649000 \\ \mathrm{C} & -3.211235000 & 0.731307000 & -1.556399000 \\ \mathrm{O} & -2.968705000 & 1.489093000 & -2.401418000 \\ \mathrm{C} & -3.040638000 & -1.806916000 & -1.242371000 \\ \mathrm{O} & -2.645141000 & -2.687812000 & -1.886836000 \\ \mathrm{C} & -4.915566000 & -0.389619000 & 1.527563000 \\ \mathrm{H} & -4.516659000 & -0.369950000 & 2.541215000\end{array}$




\begin{tabular}{|c|c|c|c|}
\hline C & -5.251970000 & -1.554434000 & 0.787861000 \\
\hline $\mathrm{H}$ & -5.183164000 & -2.583686000 & 1.135759000 \\
\hline C & -5.764606000 & -1.133184000 & -0.481212000 \\
\hline $\mathrm{H}$ & -6.124907000 & -1.785689000 & -1.274803000 \\
\hline C & -5.747114000 & 0.283557000 & -0.510415000 \\
\hline $\mathrm{H}$ & -6.090618000 & 0.907144000 & -1.334648000 \\
\hline C & -5.215660000 & 0.754323000 & 0.731793000 \\
\hline $\mathrm{H}$ & -5.112449000 & 1.793747000 & 1.036856000 \\
\hline Mn & 3.740615000 & -0.449013000 & 0.179992000 \\
\hline $\mathrm{C}$ & 1.988900000 & -0.199456000 & -0.771323000 \\
\hline O & 1.268129000 & -1.136814000 & -1.324988000 \\
\hline C & 3.175551000 & -1.803026000 & 1.300815000 \\
\hline O & 2.836394000 & -2.628630000 & 2.014636000 \\
\hline C & 3.376867000 & 0.660322000 & 1.618359000 \\
\hline 0 & 3.190117000 & 1.322415000 & 2.529607000 \\
\hline C & 4.793648000 & -0.727584000 & -1.711167000 \\
\hline $\mathrm{H}$ & 4.307759000 & -0.971030000 & -2.655197000 \\
\hline C & 5.282195000 & -1.657557000 & -0.748556000 \\
\hline $\mathrm{H}$ & 5.250474000 & -2.743540000 & -0.829018000 \\
\hline $\mathrm{C}$ & 5.877491000 & -0.915753000 & 0.320861000 \\
\hline $\mathrm{H}$ & 6.364022000 & -1.332972000 & 1.201384000 \\
\hline C & 5.756613000 & 0.465516000 & 0.006514000 \\
\hline $\mathrm{H}$ & 6.114743000 & 1.292361000 & 0.619544000 \\
\hline C & 5.084290000 & 0.585427000 & -1.240075000 \\
\hline $\mathrm{H}$ & 4.834433000 & 1.516261000 & -1.747579000 \\
\hline $\mathrm{Fe}$ & 0.026988000 & 2.093787000 & 0.064088000 \\
\hline C & -1.478686000 & 1.091569000 & 1.105090000 \\
\hline C & -1.907118000 & 2.415017000 & 0.734995000 \\
\hline $\mathrm{H}$ & -2.749251000 & 2.656370000 & 0.093255000 \\
\hline C & -1.029863000 & 3.359451000 & 1.333782000 \\
\hline $\mathrm{H}$ & -1.091391000 & 4.441251000 & 1.223763000 \\
\hline C & -0.044342000 & 2.644891000 & 2.083581000 \\
\hline $\mathrm{H}$ & 0.777464000 & 3.085106000 & 2.646520000 \\
\hline C & -0.313070000 & 1.260335000 & 1.945632000 \\
\hline $\mathrm{H}$ & 0.246801000 & 0.446186000 & 2.397906000 \\
\hline C & 1.451620000 & 1.103906000 & -1.077684000 \\
\hline C & 0.245703000 & 1.340122000 & -1.854889000 \\
\hline $\mathrm{H}$ & -0.375966000 & 0.569830000 & -2.301289000 \\
\hline C & 0.037474000 & 2.734147000 & -1.936963000 \\
\hline $\mathrm{H}$ & -0.801050000 & 3.212103000 & -2.440119000 \\
\hline C & 1.075154000 & 3.391513000 & -1.203224000 \\
\hline $\mathrm{H}$ & 1.173211000 & 4.466717000 & -1.061059000 \\
\hline C & 1.937078000 & 2.408094000 & -0.657818000 \\
\hline $\mathrm{H}$ & 2.820930000 & 2.616186000 & -0.060140000 \\
\hline C & -1.794172000 & -2.522989000 & 1.471819000 \\
\hline $\mathrm{H}$ & -1.512557000 & -2.981995000 & 0.512117000 \\
\hline $\mathrm{H}$ & -2.882848000 & -2.610170000 & 1.573842000 \\
\hline C & -1.064211000 & -3.162664000 & 2.635742000 \\
\hline $\mathrm{H}$ & -1.314439000 & -4.233576000 & 2.685791000 \\
\hline $\mathrm{H}$ & -1.356670000 & -2.698475000 & 3.589846000 \\
\hline $\mathrm{H}$ & 0.028248000 & -3.072933000 & 2.529677000 \\
\hline C & 1.534016000 & -2.559659000 & -1.244517000 \\
\hline $\mathrm{H}$ & 1.114296000 & -2.913375000 & -0.290121000 \\
\hline
\end{tabular}




$\begin{array}{lrrr}\mathrm{H} & 2.622808000 & -2.712400000 & -1.230981000 \\ \mathrm{C} & 0.877158000 & -3.237153000 & -2.427177000 \\ \mathrm{H} & 1.061755000 & -4.321000000 & -2.370701000 \\ \mathrm{H} & 1.292633000 & -2.867259000 & -3.376703000 \\ \mathrm{H} & -0.210335000 & -3.074477000 & -2.426564000\end{array}$

$3 b^{2+}: E=-5174.561800$

\begin{tabular}{|c|c|c|c|}
\hline $\mathrm{Mn}$ & -4.552710000 & -0.054431000 & 0.176723000 \\
\hline C & -2.741074000 & 0.500120000 & -0.446602000 \\
\hline O & -2.335884000 & 1.722018000 & -0.647425000 \\
\hline $\mathrm{C}$ & -3.938335000 & -1.241622000 & 1.452249000 \\
\hline O & -3.572693000 & -1.972466000 & 2.250271000 \\
\hline C & -4.779719000 & 1.134522000 & 1.602135000 \\
\hline 0 & -4.939032000 & 1.839392000 & 2.482507000 \\
\hline C & -5.258571000 & -0.068219000 & -1.861375000 \\
\hline $\mathrm{H}$ & -4.684349000 & 0.282309000 & -2.718124000 \\
\hline $\mathrm{C}$ & -6.160845000 & 0.708858000 & -1.076884000 \\
\hline $\mathrm{H}$ & -6.403389000 & 1.761157000 & -1.222381000 \\
\hline C & -6.759001000 & -0.155959000 & -0.107875000 \\
\hline $\mathrm{H}$ & -7.501602000 & 0.131008000 & 0.636515000 \\
\hline C & -6.228990000 & -1.455519000 & -0.292004000 \\
\hline $\mathrm{H}$ & -6.489566000 & -2.338256000 & 0.291989000 \\
\hline $\mathrm{C}$ & -5.292162000 & -1.407486000 & -1.366106000 \\
\hline $\mathrm{H}$ & -4.733040000 & -2.252909000 & -1.764651000 \\
\hline Mn & 4.552349000 & -0.054703000 & -0.177234000 \\
\hline $\mathrm{C}$ & 2.741188000 & 0.500245000 & 0.446919000 \\
\hline O & 2.336536000 & 1.722300000 & 0.647864000 \\
\hline C & 4.778774000 & 1.134236000 & -1.602786000 \\
\hline 0 & 4.937391000 & 1.839248000 & -2.483163000 \\
\hline C & 3.937111000 & -1.241925000 & -1.452327000 \\
\hline 0 & 3.570846000 & -1.972916000 & -2.249930000 \\
\hline $\mathrm{C}$ & 5.258714000 & -0.069336000 & 1.860657000 \\
\hline $\mathrm{H}$ & 4.684563000 & 0.280565000 & 2.717708000 \\
\hline C & 6.160623000 & 0.708444000 & 1.076422000 \\
\hline $\mathrm{H}$ & 6.402910000 & 1.760726000 & 1.222475000 \\
\hline C & 6.758843000 & -0.155654000 & 0.106838000 \\
\hline $\mathrm{H}$ & 7.501179000 & 0.131958000 & -0.637568000 \\
\hline $\mathrm{C}$ & 6.229197000 & -1.455459000 & 0.290277000 \\
\hline $\mathrm{H}$ & 6.489918000 & -2.337790000 & -0.294264000 \\
\hline C & 5.292540000 & -1.408302000 & 1.364599000 \\
\hline $\mathrm{H}$ & 4.733759000 & -2.254124000 & 1.762780000 \\
\hline $\mathrm{Fe}$ & 0.000101000 & -1.150190000 & 0.000492000 \\
\hline C & -1.737671000 & -0.444736000 & -0.932709000 \\
\hline $\mathrm{C}$ & -1.748355000 & -1.888770000 & -0.846754000 \\
\hline $\mathrm{H}$ & -2.478339000 & -2.505562000 & -0.329403000 \\
\hline C & -0.634985000 & -2.385639000 & -1.571071000 \\
\hline $\mathrm{H}$ & -0.370646000 & -3.436171000 & -1.684490000 \\
\hline $\mathrm{C}$ & 0.093730000 & -1.276317000 & -2.095030000 \\
\hline $\mathrm{H}$ & 1.000007000 & -1.342957000 & -2.694173000 \\
\hline $\mathrm{C}$ & -0.558218000 & -0.082770000 & -1.691569000 \\
\hline $\mathrm{H}$ & -0.259838000 & 0.933908000 & -1.935885000 \\
\hline $\mathrm{C}$ & 1.737850000 & -0.444478000 & 0.933451000 \\
\hline
\end{tabular}




$\begin{array}{lrrr}\mathrm{C} & 0.558360000 & -0.082313000 & 1.692227000 \\ \mathrm{H} & 0.259969000 & 0.934430000 & 1.936237000 \\ \mathrm{C} & -0.093577000 & -1.275776000 & 2.095994000 \\ \mathrm{H} & -0.999850000 & -1.342289000 & 2.695138000 \\ \mathrm{C} & 0.635197000 & -2.385209000 & 1.572351000 \\ \mathrm{H} & 0.370890000 & -3.435723000 & 1.686014000 \\ \mathrm{C} & 1.748602000 & -1.888482000 & 0.847940000 \\ \mathrm{H} & 2.478593000 & -2.505402000 & 0.330747000 \\ \mathrm{C} & -3.120432000 & 2.916477000 & -0.363253000 \\ \mathrm{H} & -3.037917000 & 3.108266000 & 0.717469000 \\ \mathrm{H} & -4.170127000 & 2.704889000 & -0.609843000 \\ \mathrm{C} & -2.561441000 & 4.060161000 & -1.178347000 \\ \mathrm{H} & -3.132166000 & 4.974935000 & -0.957521000 \\ \mathrm{H} & -2.639602000 & 3.859944000 & -2.257254000 \\ \mathrm{H} & -1.507234000 & 4.249196000 & -0.926925000 \\ \mathrm{C} & 3.121464000 & 2.916377000 & 0.363151000 \\ \mathrm{H} & 3.037784000 & 3.108461000 & -0.717444000 \\ \mathrm{H} & 4.171330000 & 2.704097000 & 0.608409000 \\ \mathrm{C} & 2.564116000 & 4.060171000 & 1.179216000 \\ \mathrm{H} & 3.135056000 & 4.974690000 & 0.957882000 \\ \mathrm{H} & 2.643512000 & 3.859668000 & 2.257981000 \\ \mathrm{H} & 1.509695000 & 4.249840000 & 0.929168000\end{array}$

$3 b^{+3}: E=-5174.126832$

$\begin{array}{lrrr}\mathrm{Mn} & 4.645584000 & -0.039273000 & -0.173223000 \\ \mathrm{C} & 2.848910000 & 0.502197000 & 0.431353000 \\ \mathrm{O} & 2.417281000 & 1.710360000 & 0.621298000 \\ \mathrm{C} & 3.980379000 & -1.173468000 & -1.468189000 \\ \mathrm{O} & 3.536793000 & -1.866465000 & -2.261236000 \\ \mathrm{C} & 4.966928000 & 1.199363000 & -1.577157000 \\ \mathrm{O} & 5.180972000 & 1.918644000 & -2.427681000 \\ \mathrm{C} & 5.342101000 & -0.313700000 & 1.852063000 \\ \mathrm{H} & 4.760295000 & -0.116945000 & 2.752187000 \\ \mathrm{C} & 6.224620000 & 0.604361000 & 1.210134000 \\ \mathrm{H} & 6.427394000 & 1.630090000 & 1.519277000 \\ \mathrm{C} & 6.867030000 & -0.080728000 & 0.134770000 \\ \mathrm{H} & 7.612569000 & 0.343402000 & -0.539348000 \\ \mathrm{C} & 6.378565000 & -1.409213000 & 0.098948000 \\ \mathrm{H} & 6.690811000 & -2.184349000 & -0.601619000 \\ \mathrm{C} & 5.424268000 & -1.558935000 & 1.153952000 \\ \mathrm{H} & 4.920776000 & -2.485995000 & 1.426503000 \\ \mathrm{Mn} & -4.645739000 & -0.048057000 & 0.169162000 \\ \mathrm{C} & -2.853445000 & 0.513658000 & -0.432744000 \\ \mathrm{O} & -2.431139000 & 1.727684000 & -0.606227000 \\ \mathrm{C} & -4.958560000 & 1.164978000 & 1.596330000 \\ \mathrm{O} & -5.166717000 & 1.869351000 & 2.460754000 \\ \mathrm{C} & -3.964933000 & -1.202901000 & 1.437837000 \\ \mathrm{O} & -3.509637000 & -1.907666000 & 2.213631000 \\ \mathrm{C} & -5.356042000 & -0.299336000 & -1.855087000 \\ \mathrm{H} & -4.779015000 & -0.094223000 & -2.756420000 \\ \mathrm{C} & -6.232835000 & 0.613573000 & -1.198218000 \\ \mathrm{H} & -6.435588000 & 1.642757000 & -1.495577000\end{array}$




$\begin{array}{lrrr}\mathrm{C} & -6.869555000 & -0.081061000 & -0.125744000 \\ \mathrm{H} & -7.609820000 & 0.337767000 & 0.557435000 \\ \mathrm{C} & -6.383283000 & -1.410638000 & -0.106233000 \\ \mathrm{H} & -6.692683000 & -2.192384000 & 0.588208000 \\ \mathrm{C} & -5.436545000 & -1.551430000 & -1.169541000 \\ \mathrm{H} & -4.938618000 & -2.477238000 & -1.456191000 \\ \mathrm{Fe} & -0.001870000 & -1.157175000 & 0.007272000 \\ \mathrm{C} & 1.800076000 & -0.450355000 & 0.908426000 \\ \mathrm{C} & 1.790738000 & -1.892611000 & 0.819574000 \\ \mathrm{H} & 2.489878000 & -2.514562000 & 0.264817000 \\ \mathrm{C} & 0.710635000 & -2.386701000 & 1.606754000 \\ \mathrm{H} & 0.443332000 & -3.436228000 & 1.737832000 \\ \mathrm{C} & 0.036817000 & -1.272459000 & 2.183486000 \\ \mathrm{H} & -0.842500000 & -1.326104000 & 2.826587000 \\ \mathrm{C} & 0.682037000 & -0.087375000 & 1.747510000 \\ \mathrm{H} & 0.402906000 & 0.931764000 & 2.011241000 \\ \mathrm{C} & -1.793679000 & -0.423045000 & -0.914847000 \\ \mathrm{C} & -0.640735000 & -0.033514000 & -1.695235000 \\ \mathrm{H} & -0.347379000 & 0.992992000 & -1.909184000 \\ \mathrm{C} & 0.004186000 & -1.208067000 & -2.164365000 \\ \mathrm{H} & 0.902086000 & -1.247502000 & -2.782052000 \\ \mathrm{C} & -0.704272000 & -2.335901000 & -1.662912000 \\ \mathrm{H} & -0.443823000 & -3.382684000 & -1.826571000 \\ \mathrm{C} & -1.800852000 & -1.862397000 & -0.891413000 \\ \mathrm{H} & -2.521178000 & -2.500506000 & -0.383843000 \\ \mathrm{C} & 3.225795000 & 2.925246000 & 0.416054000 \\ \mathrm{H} & 3.164635000 & 3.157858000 & -0.657846000 \\ \mathrm{H} & 4.263460000 & 2.675685000 & 0.677971000 \\ \mathrm{C} & 2.661022000 & 4.032654000 & 1.271962000 \\ \mathrm{H} & 3.250745000 & 4.946729000 & 1.101619000 \\ \mathrm{H} & 2.719298000 & 3.788502000 & 2.342928000 \\ \mathrm{H} & 1.617146000 & 4.254440000 & 1.005210000 \\ \mathrm{C} & -3.248620000 & 2.933563000 & -0.387877000 \\ \mathrm{H} & -3.177036000 & 3.163623000 & 0.685970000 \\ \mathrm{H} & -4.286982000 & 2.675215000 & -0.638079000 \\ \mathrm{C} & -2.704803000 & 4.048996000 & -1.247156000 \\ \mathrm{H} & -3.301311000 & 4.956833000 & -1.067425000 \\ \mathrm{H} & -2.772957000 & 3.806872000 & -2.317999000 \\ \mathrm{H} & -1.660041000 & 4.280197000 & -0.992119000\end{array}$


Table S2. DFT-calculated $g$-tensors and hyperfine coupling parameters (hseh1pbe functional).

\begin{tabular}{|c|c|c|c|c|}
\hline & 6-311+g(d,p), DCM & $6-311+g(d, p)$ & $6-311 \mathrm{~g}(d, p)$ & SDD \\
\hline ge & 2.0023193 & 2.0023193 & 2.0023193 & 2.0023193 \\
\hline xx shift & -4632.9 & -5018 & -4510.8 & -2849.6 \\
\hline yy shift & 31090.6 & 31140 & 33090.8 & 9549.2 \\
\hline zz shift & 149600.2 & 151317.5 & 148546.9 & 57350.2 \\
\hline gxx calc & 1.998 & 1.997 & 1.998 & 1.999 \\
\hline gyy calc & 2.033 & 2.033 & 2.035 & 2.012 \\
\hline gzz calc & 2.152 & 2.154 & 2.151 & 2.060 \\
\hline Mulliken spin density (Mn) & 1.171117 & 1.085881 & 1.137988 & 1.288229 \\
\hline Isotr. Fermi CC (Mn) & -40.28306 & -41.32886 & -40.06647 & -0.00977 \\
\hline Spin-dipole C (Mn) XX & 0.572054 & 0.136272 & 0.001135 & 0.15867 \\
\hline Spin-dipole C (Mn) YY & 0.243094 & 0.851704 & 0.956335 & 0.761654 \\
\hline Spin-dipole C (Mn) ZZ & -0.815148 & -0.987977 & -0.95747 & -0.920324 \\
\hline Spin-dipole C (Mn) XY & -0.55689 & -0.1361 & -0.072735 & -0.097623 \\
\hline Spin-dipole C (Mn) XZ & -0.754444 & -1.055717 & -1.03027 & -1.062678 \\
\hline Spin-dipole C (Mn) YZ & -0.62088 & -0.193459 & -0.205451 & -0.234293 \\
\hline Anis spin-dipole Baa (Mn) & -71.104 & -77.409 & -76.83 & -75.293 \\
\hline Anis spin-dipole Bbb (Mn) & 22.278 & 36.133 & 30.636 & 35.728 \\
\hline Anis spin-dipole Bcc (Mn) & 48.826 & 41.276 & 46.194 & 39.565 \\
\hline Mulliken spin density $(\mathrm{Fe})$ & -0.012732 & -0.013773 & -0.007966 & -0.028687 \\
\hline Isotr. Fermi $\mathrm{CC}(\mathrm{Fe})$ & -0.06605 & -0.04315 & -0.0399 & 0.00004 \\
\hline Anis spin-dipole $\mathrm{Baa}(\mathrm{Fe})$ & -0.166 & -0.164 & -0.176 & -0.752 \\
\hline Anis spin-dipole $\mathrm{Bbb}(\mathrm{Fe})$ & 0.047 & 0.005 & -0.001 & -0.227 \\
\hline Anis spin-dipole Bcc (Fe) & 0.119 & 0.159 & 0.177 & 0.979 \\
\hline $\operatorname{Mn} 4 \mathrm{~s}$ & 0.357 & 0.353 & 0.346 & 0.318 \\
\hline Mn 4px & 0.348 & 0.329 & 0.021 & 0.317 \\
\hline Mn 4py & 0.356 & 0.342 & 0.024 & 0.324 \\
\hline $\mathrm{Mn} 4 \mathrm{pz}$ & 0.369 & 0.371 & 0.024 & 0.359 \\
\hline Mn 3dxy & 1.318 & 1.330 & 1.246 & 1.357 \\
\hline Mn 3dxz & 1.468 & 1.475 & 1.339 & 1.435 \\
\hline Mn 3dyz & 1.457 & 1.188 & 1.094 & 1.205 \\
\hline Mn 3dx2-y2 & 1.095 & 1.174 & 1.046 & 1.144 \\
\hline Mn 3dz2 & 1.314 & 1.428 & 1.263 & 1.434 \\
\hline Valence e sum & 8.082 & 7.990 & 6.404 & 7.895 \\
\hline $3 \mathrm{~d}$ e sum & 6.652 & 6.594 & 5.989 & 6.576 \\
\hline
\end{tabular}


Table S3. Cartesian coordinates and thermochemical parameters for compound 3a calculated at the hseh1pbe/6-311+g(d,p) level of theory in a $\mathrm{CH}_{2} \mathrm{Cl}_{2}$ solvent continuum.

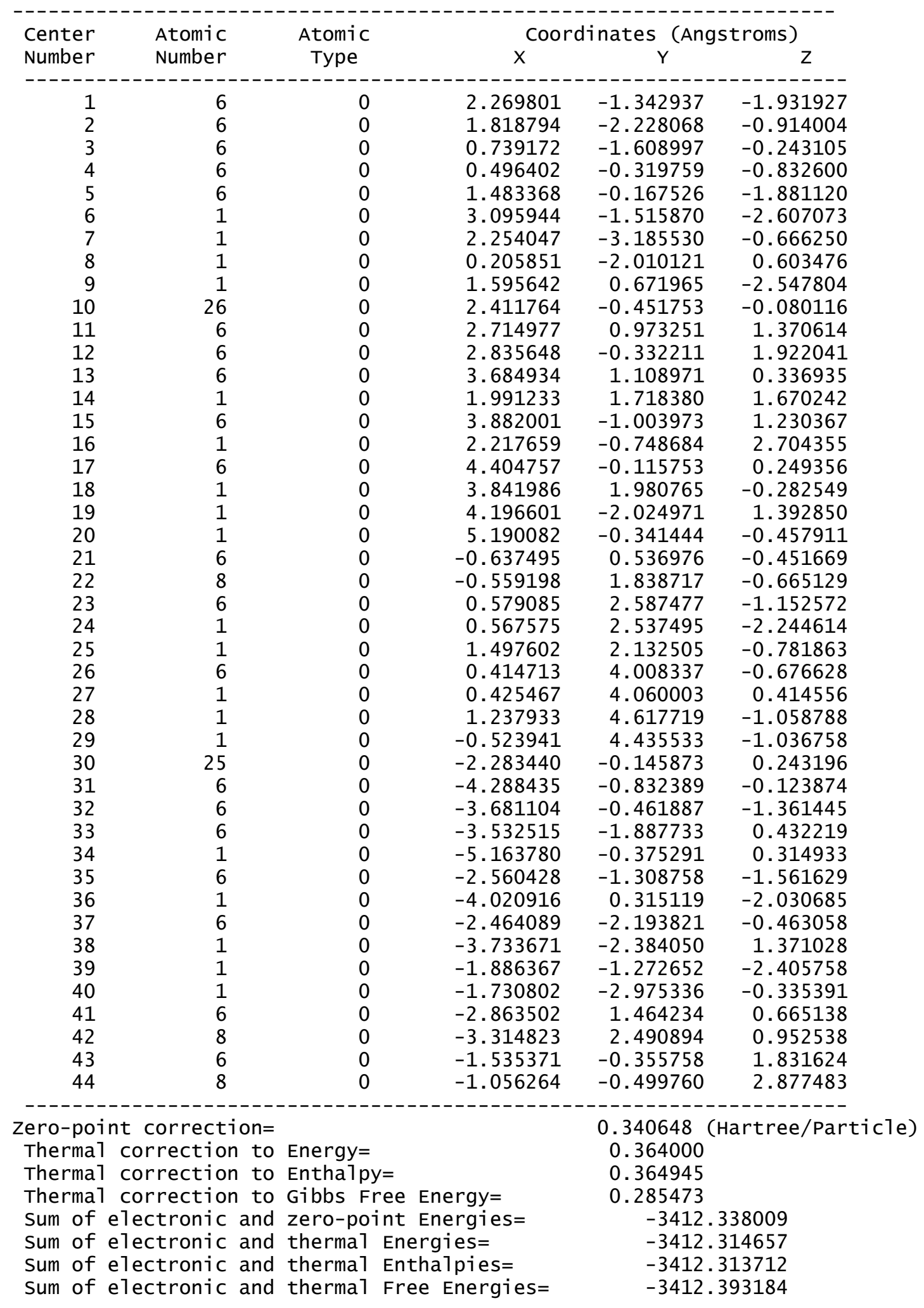


Table S4. Cartesian coordinates and thermochemical parameters for compound $\mathbf{3 a}^{\mathbf{}}{ }^{+}$ calculated at the hseh1pbe/6-311+g(d,p) level of theory in a $\mathrm{CH}_{2} \mathrm{Cl}_{2}$ solvent continuum.

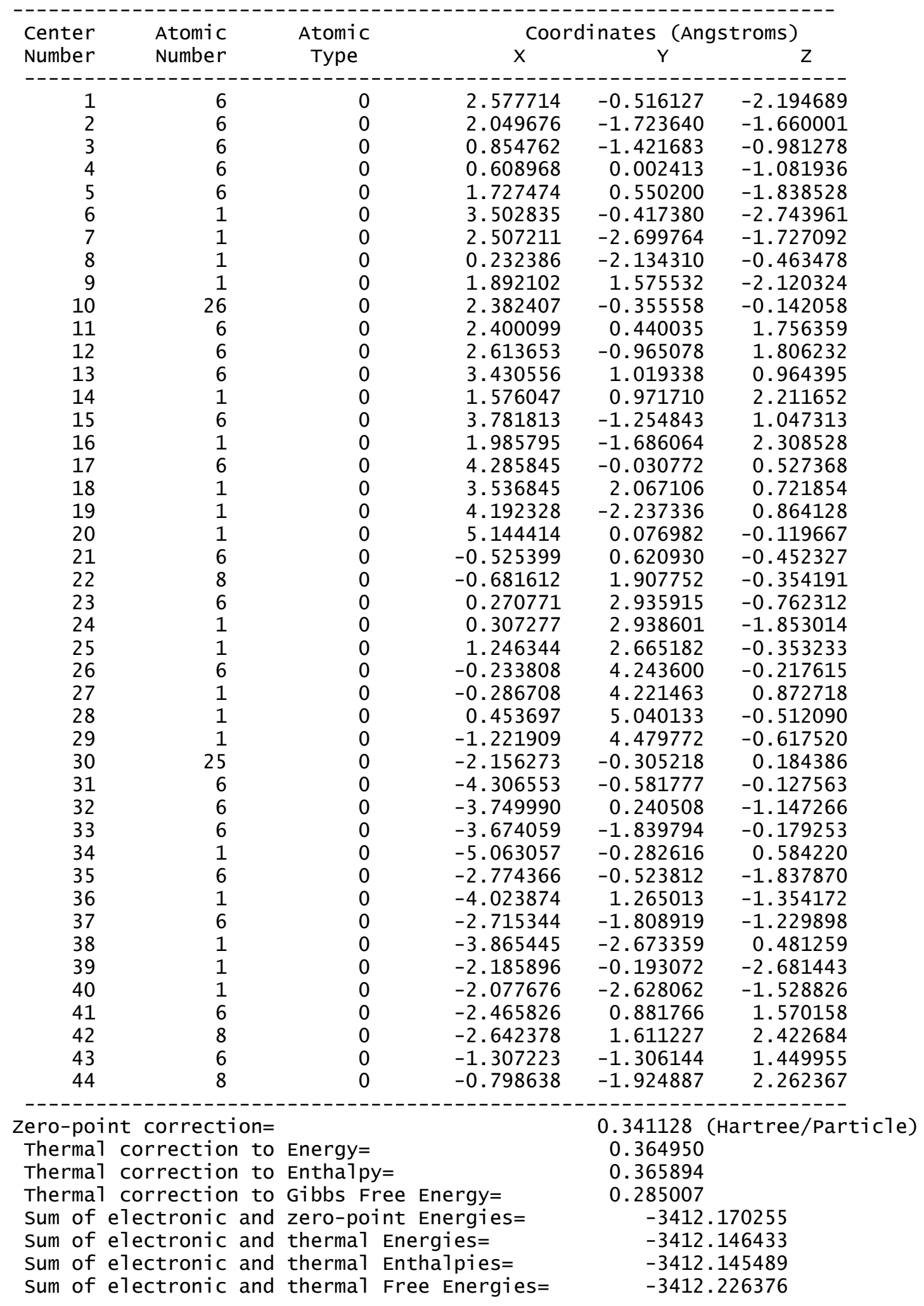


Table S5. Cartesian coordinates and thermochemical parameters for compound 3a calculated at the hseh1pbe/6-311+g(d,p) level of theory in vacuo.

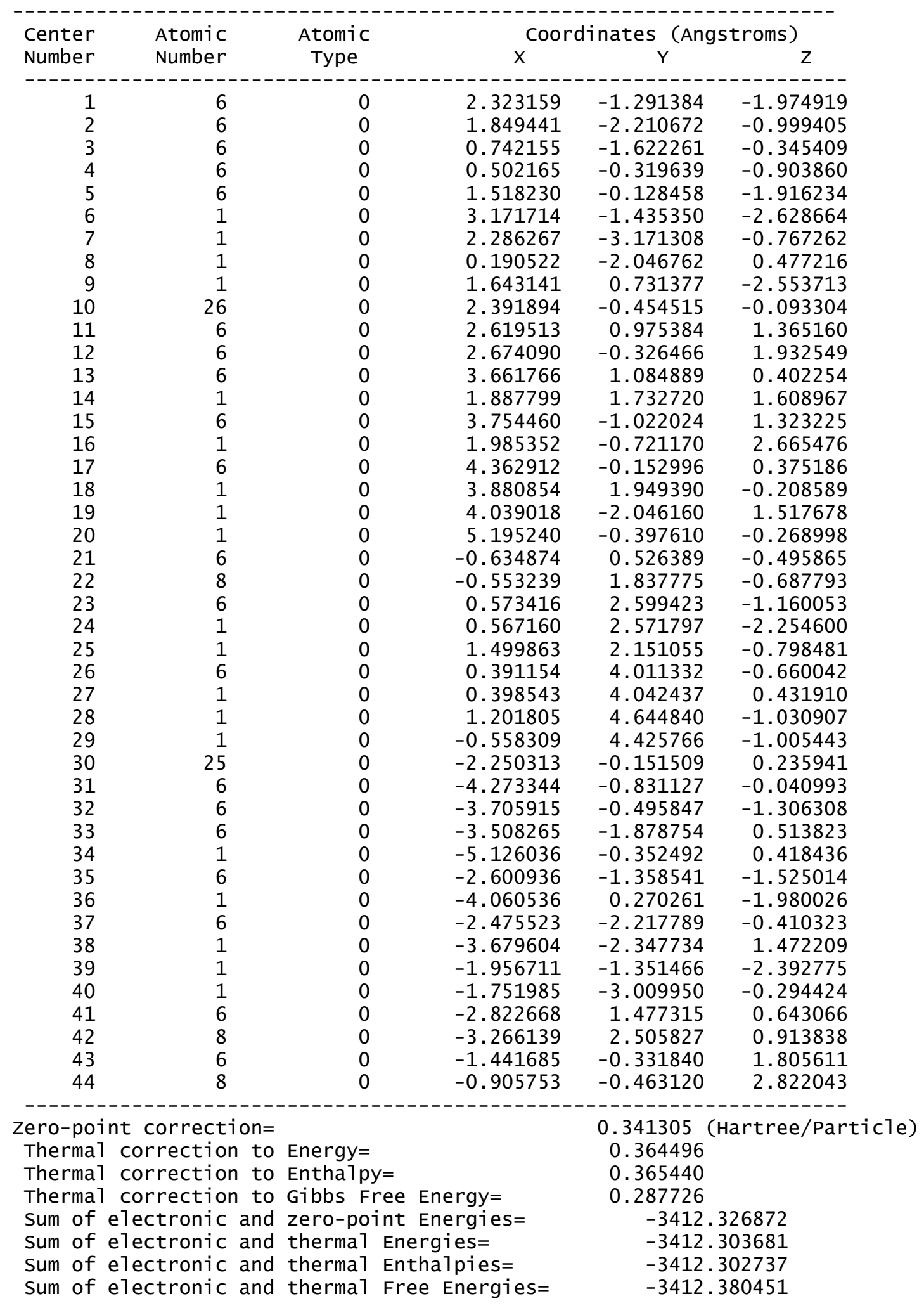


Table S6. Cartesian coordinates and thermochemical parameters for compound $\mathbf{3 a}^{\mathbf{}}{ }^{+}$ calculated at the hseh $1 \mathrm{pbe} / 6-311+\mathrm{g}(\mathrm{d}, \mathrm{p})$ level of theory in vacuo.

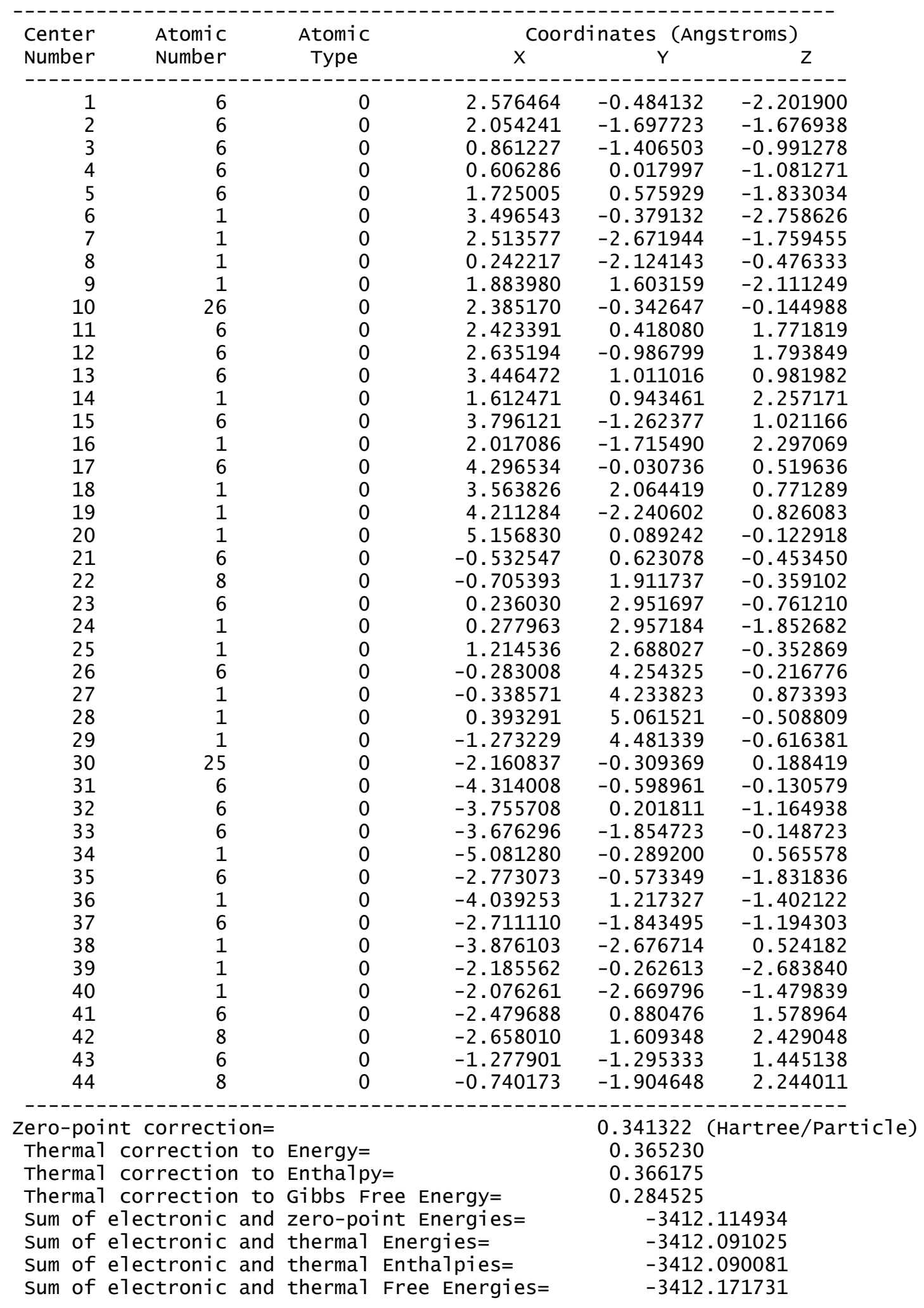


Table S7. Cartesian coordinates and thermochemical parameters for compound 3a calculated at the hseh1pbe/6-311g(d,p) level of theory in vacuo.

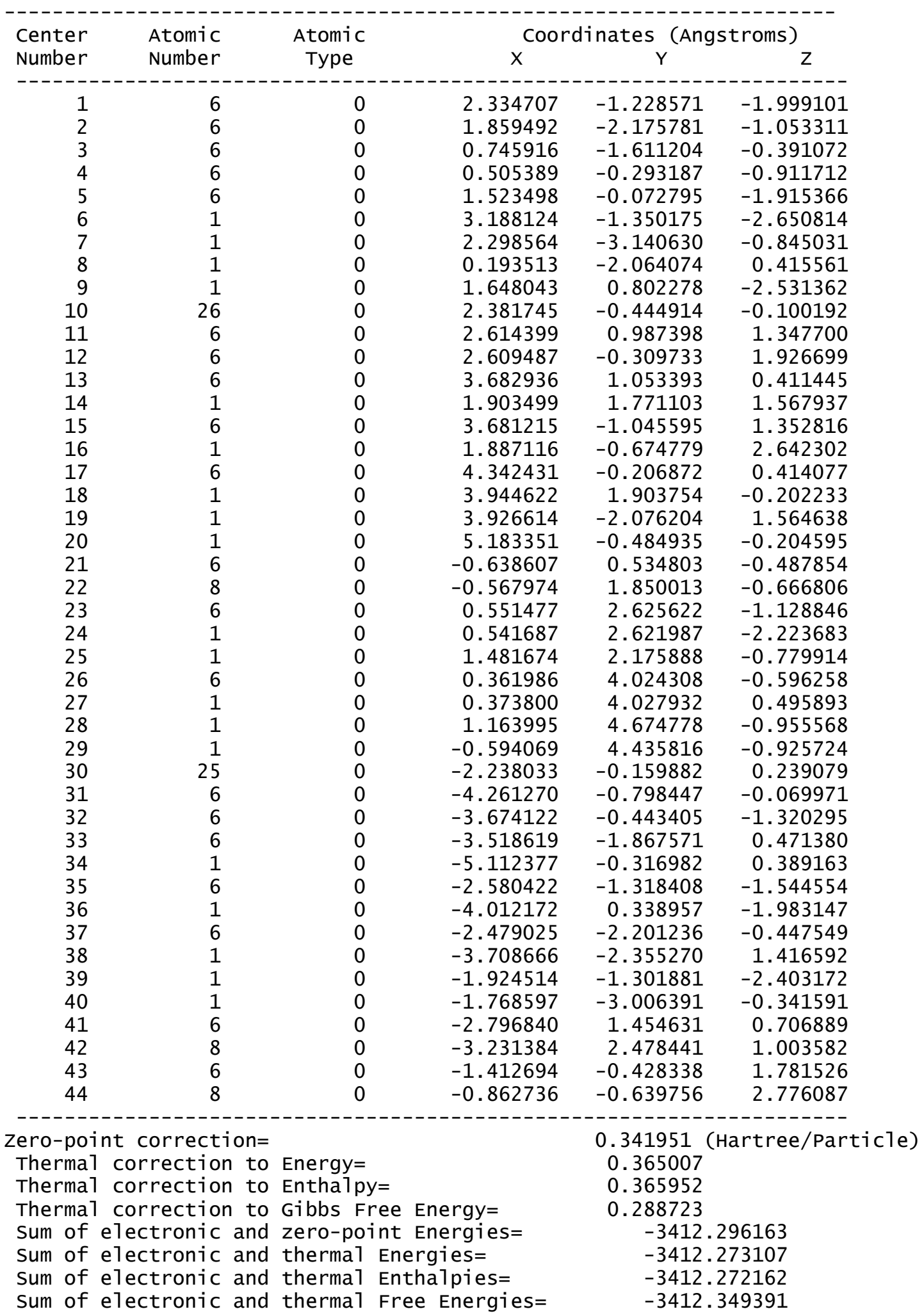


Table S8. Cartesian coordinates and thermochemical parameters for compound $\mathbf{3 a}^{\mathbf{}}{ }^{+}$ calculated at the hseh $1 \mathrm{pbe} / 6-311 \mathrm{~g}(\mathrm{~d}, \mathrm{p})$ level of theory in vacuo.

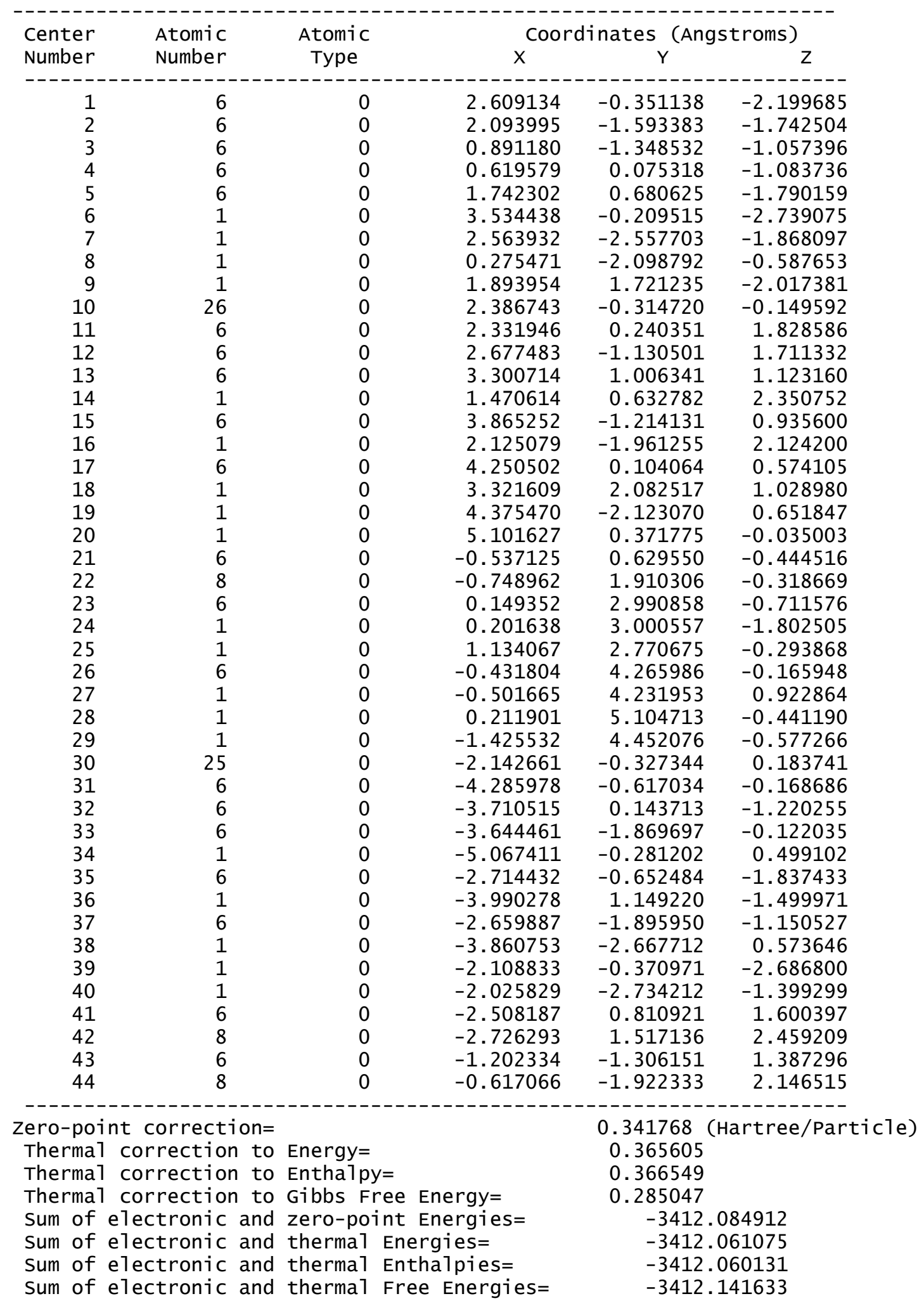


Table S9. Cartesian coordinates and thermochemical parameters for compound 3a calculated at the hseh1pbe/SDD level of theory in vacuo.

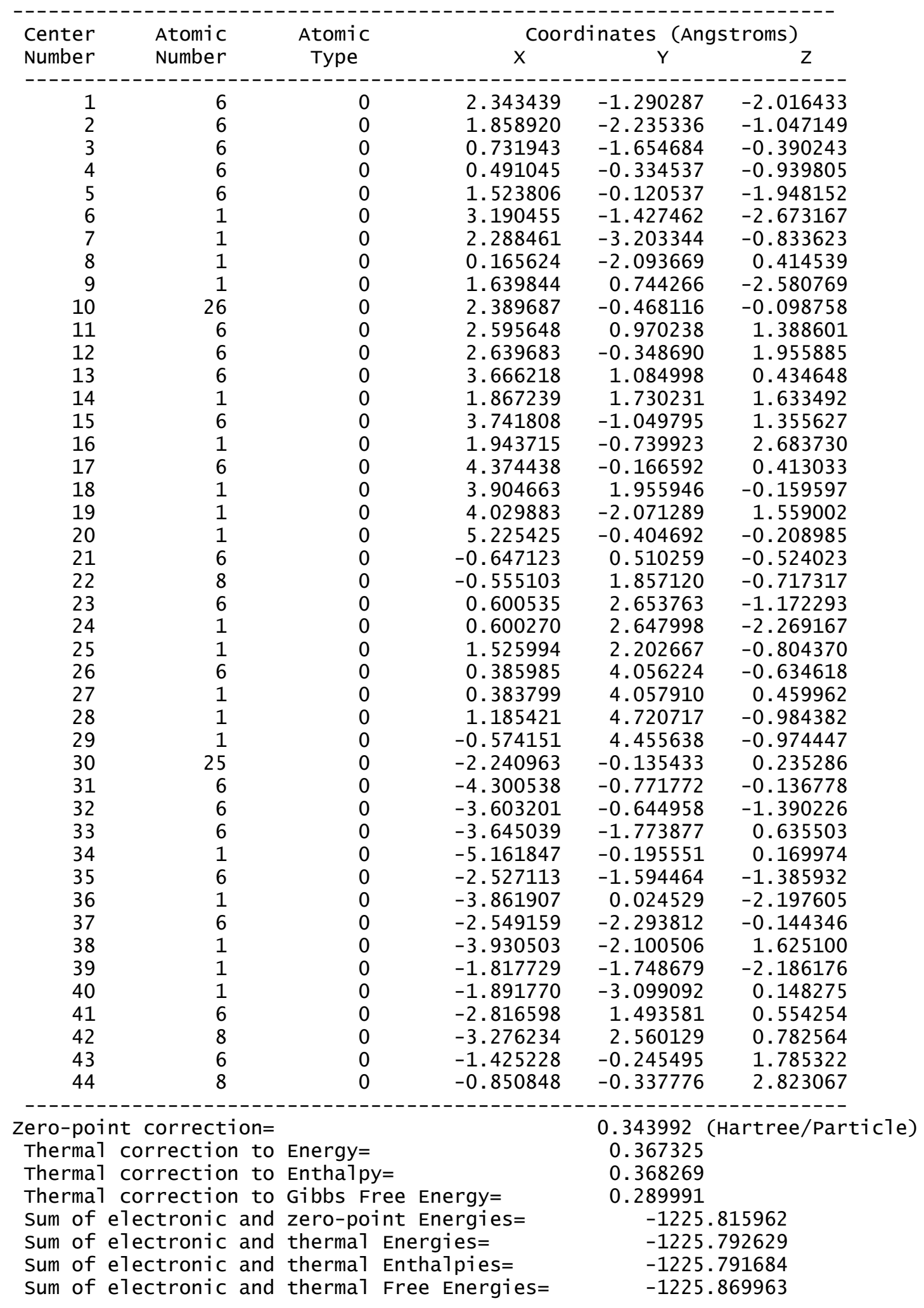


Table S10. Cartesian coordinates and thermochemical parameters for compound $\mathbf{3 a}^{\mathbf{*}}$ calculated at the hseh1pbe/SDD level of theory in vacuo.

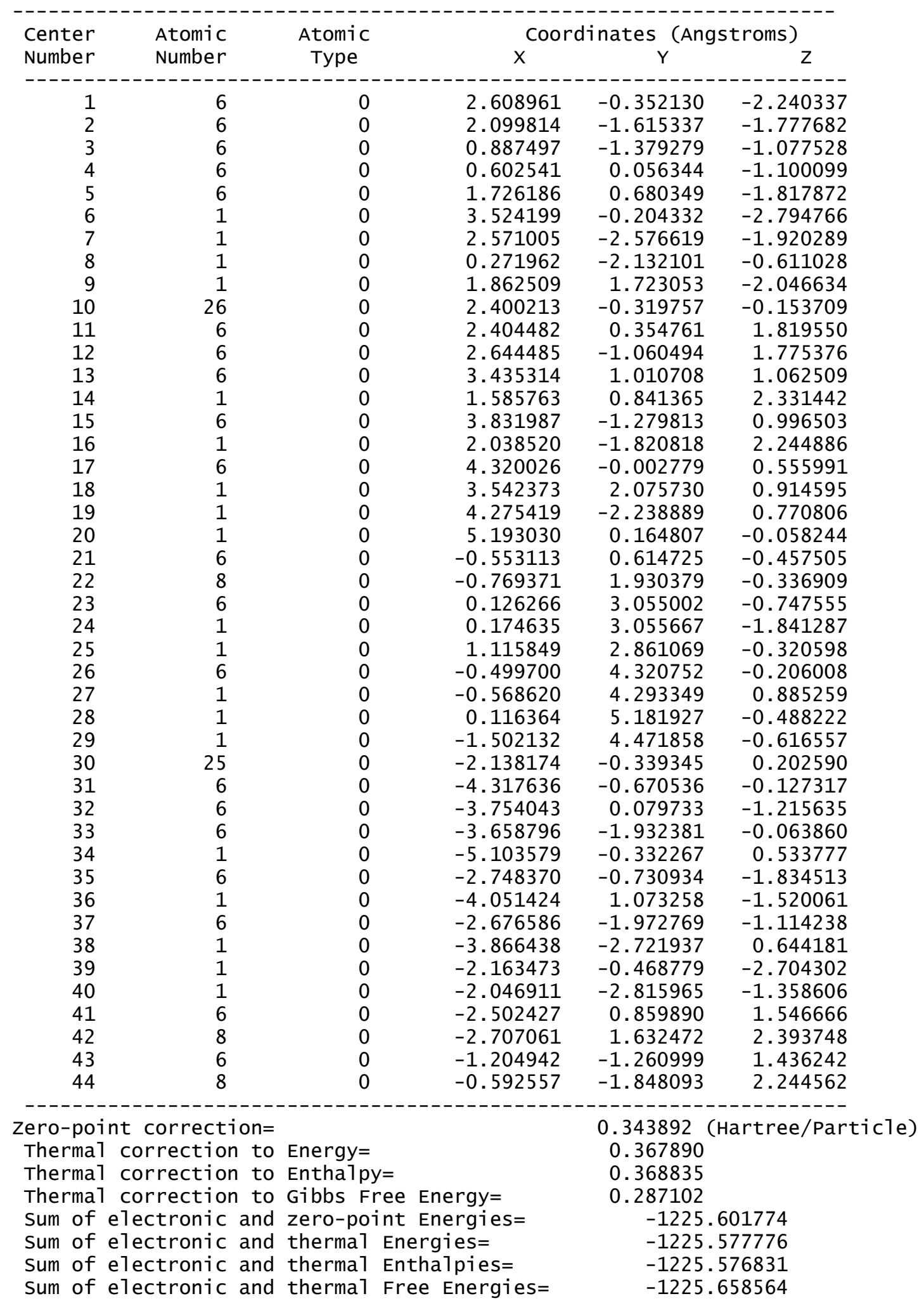




\section{References}

[1] a) B. Van der Westhuizen, P. J. Swarts, I. Strydom, D. C. Liles, I. Fernández, J. C. Swarts, D. I. Bezuidenhout, Dalton Trans. 2013, 42, 5367-5378; b) B. Van der Westhuizen, P. J. Swarts, L. M. van Jaarsveld, D. C. Liles, U. Siegert, J. C. Swarts, I. Fernández, D. I. Bezuidenhout, Inorg. Chem. 2013, 52, 6674-6684.

[2] D. I. Bezuidenhout, I. Fernández, B. Van der Westhuizen,, P. J. Swarts, J. C. Swarts, Organometallics, 2013, 32, 7334-7344. 